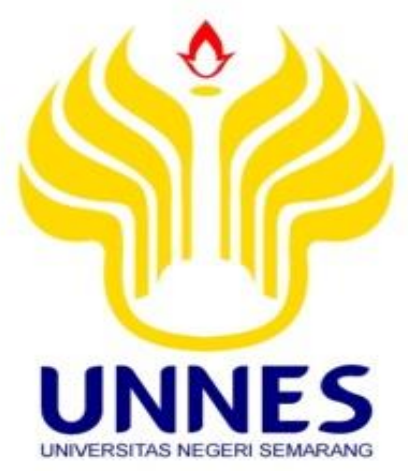

\title{
PEMBELAJARAN EKSTRAKURIKULER PADUAN SUARA DI SMP NEGERI 2 SEMARANG
}

\section{SKRIPSI}

untuk memperoleh gelar Sarjana Pendidikan

$\begin{array}{ll} & \text { oleh } \\ \text { Nama } & : \text { A. Ines Yulivita } \\ \text { NIM } & : \text { 250141158 } \\ \text { Program Studi } & : \text { Pendidikan Seni Musik } \\ \text { Jurusan } & : \text { Pendidikan Sendratasik }\end{array}$

FAKULTAS BAHASA DAN SENI

UNIVERSITAS NEGERI SEMARANG 


\section{PENGESAHAN KELULUSAN}

Skripsi ini telah dipertahankan di hadapan sidang Panitia Ujian Skripsi Jurusan Sendratasik, Fakultas Bahasa dan Seni, Universitas Negeri Semarang.

$\begin{array}{ll}\text { Pada Hari } & \text { : Selasa } \\ \text { Tanggal } & : 25 \text { April } 2017\end{array}$

Panitia Ujian Skripsi

Prof. Dr. M. Jazuli, M. Hum. (196107041988031003)

Ketua

Dr. Udi Utomo, M. Si. (196708311993011001)

Sekretaris

Drs. Eko Raharjo, M.Hum. (196510181992031001)

Penguji I

Dra. Siti Aesijah, M.Pd. (196512191991032003)

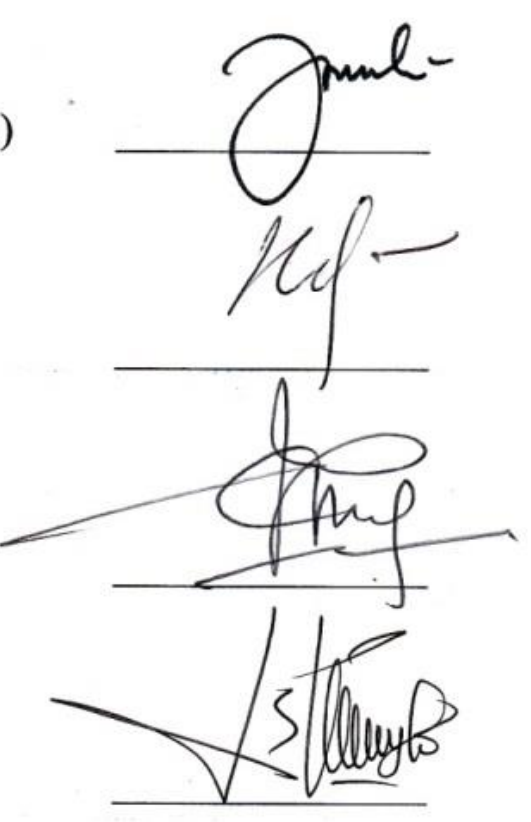

Penguji II/Pembimbing II

Drs. Suharto, S.Pd, M. Hum. (196510181990031002)

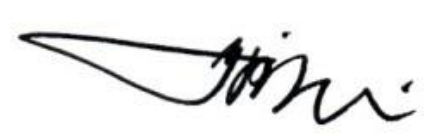

Penguji III/Pembimbing I

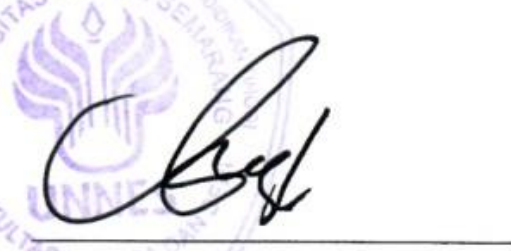

Prof. Dr. Agus Nuryatin, M.Hum. (196008031989011001)

Dekan Fakultas Bahasa dan Seni 


\section{PERNYATAAN}

Dengan ini saya:

Nama $\quad$ : A. Ines Yulivita

NIM : : 2501411158

Prodi/Jurusan : Pendidikan Seni Musik/ PSDTM

Fakultas : Bahasa dan Seni

Menyatakan bahwa skripsi yang berjudul "Pembelajaran Ekstrakurikuler Paduan Suara di SMP Negeri 2 Semarang" yang saya tulis dalam rangka menyelesaikan salah satu syarat untuk memperoleh gelar Sarjana Pendidikan ini benar-benar karya saya sendiri yang saya selesaikan melalui proses penelitian, bimbingan, diskusi. Semua kutipan, baik langsung maupun tidak langsung, baik yang diperoleh dari sumber perpustakaan, wawancara langsung, dan sumber lainnya telah disertai keterangan mengenai identitas sumbernya dan dikutip atau dirujuk berdasarkan kode etik ilmiah.

Semarang, Maret 2017

Pembuat pernyataan

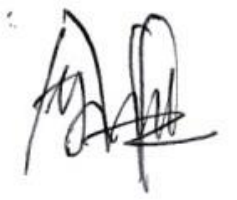

A. Ines Yulivita

NIM. 2501411158 


\section{MOTTO DAN PERSEMBAHAN}

\section{MOTTO:}

1. "Pendidikan merupakan perlengkapan paling baik untuk hari tua." (Aristoteles)

2. "Orang yang tidak pernah melakukan kesalahan adalah orang yang tidak pernah mencoba melakukan hal baru." (A. Einstein)

3. "Banyak kegagalan dalam hidup ini dikarenakan orang-orang tidak menyadari betapa dekatnya mereka dengan keberhasilan saat mereka menyerah." (Thomas Alva Edison)

Skripsi ini saya persembahkan untuk:

1. Kedua orang tuaku tercinta

(Bapak Subagiyo dan Ibu Sustiana

2. Adik-adikku tersayang

(Birgita Iyo dan Cornelius Ibenviter)

3. Sahabatku (Adi Prastyo) dan

seluruh keluarga besarku 


\section{KATA PENGANTAR}

Segala puji syukur kepada Tuhan Yang Maha Esa yang telah melimpahkan berkat dan karunia-Nya kepada penulis, sehingga penulis dapat menyelesaikan skripsi yang berjudul "Pembelajaran Ekstrakurikuler Paduan Suara di SMP Negeri 2 Semarang”.

Skripsi ini diajukan untuk memenuhi salah satu syarat memperoleh gelar Sarjana Pendidikan Jurusan Sendratasik, Fakultas Bahasa dan Seni Universitas Negeri Semarang. Selesainya skripsi ini tidak lepas dari kerjasama dan bantuan semua pihak. Oleh karena itu pada kesempatan ini, penulis menyampaikan terimakasih kepada :

1. Bapak Prof. Dr. Fathur Rokhman, M.Hum., Rektor Universitas Negeri Semarang yang telah memberikan ijin studi di Universitas Negeri Semarang;

2. Bapak Prof. Dr. Agus Nuryatin, M.Hum., Dekan Fakultas Bahasa dan Seni yang telah memberikan ijin untuk melaksanakan penelitian;

3. Bapak Dr. Udi Utomo, M.Si., Ketua Jurusan Pendidikan Sendratasik yang telah memberikan kemudahan dalam proses penyusunan skripsi ini.

4. Bapak Drs. Suharto, S.Pd, M.Hum, dosen pembimbing I dan Ibu Dra. Siti Aesijah, M.Pd, dosen pembimbing II, yang telah memberikan bimbingan, saran, koreksi, masukan, dan pengarahan kepada penulis dalam menyelesaikan skripsi ini.

5. Semua dosen jurusan Pendidikan Seni Drama, Tari, dan Musik Universitas Negeri Semarang yang telah memberikan bekal ilmu pengetahuan. 
6. Bapak Teguh Waluyo S.Pd, MM, kepala SMP Negeri 2 Semarang yang telah memberikan ijin kepada penulis untuk melakukan penelitian di SMP Negeri 2 Semarang.

7. Bapak Sudaryono S.Pd, selaku guru seni budaya dan pembina esktrakurikuler paduan suara SMP Negeri 2 Semarang yang telah membantu dalam penelitian dan memberikan arahan.

8. Staf Tata Usaha SMP Negeri 2 Semarang yang telah membantu dalam pelaksanaan penelitian.

9. Siswa-siswi angota paduan suara SMP Negeri 2 Semarang yang telah membantu dalam melakukan penelitian ini.

10. Semua pihak yang telah membantu dalam penyusunan skripsi ini, yang tidak dapat penulis sebutkan satu persatu, sehingga penulis dapat menyelesaikan skripsi ini.

Skripsi ini masih jauh dari sempurna, untuk itu kritik dan saran sangat penulis harapkan. Akhir kata, semoga skripsi ini dapat memberikan manfaat bagi pembaca khususnya, dan bagi dunia pendidikan pada umumnya.

Semarang, Maret 2017

Penulis 


\begin{abstract}
ABSTRAK
Yulivita, A. Ines. 2017. Pembelajaran Ekstrakurikuler Paduan Suara Di SMP Negeri 2 Semarang. Skripsi, Jurusan Sendratasik, Fakultas Bahasa dan Seni, Universitas Negeri Semarang.

Pembelajaran ekstrakurikuler paduan suara di SMP Negeri 2 Semarang merupakan salah satu kegiatan ekstrakurikuler dalam bidang seni musik. Banyak prestasi yang telah diraih oleh paduan suara SMP Negeri 2 Semarang baik dalam tingkat propinsi maupun tingkat nasional. Rumusan masalah dalam penelitian ini adalah bagaimana proses pembelajaran esktrakurikuler paduan suara di SMP Negeri 2 Semarang dan faktor-faktor yang mempengaruhinya. Manfaat dari penelitian ini ada 2 yaitu teoritis dan praktis. Manfaat teoritis sebagai kontribusi bagi kepustakaan, bagi penulis selanjutnya agar dapat sebagai dasar rujukan penulisan lebih lanjut. Manfaat praktis yaitu bagi peneliti dapat menambah wawasan dalam pelaksanaan pembelajaran bidang vokal khususnya paduan suara, bagi paduan suara SMP Negeri 2 Semarang dapat menjadi gambaran/ deskripsi tertulis tentang pembelajaran paduan suara.

Penelitian ini menggunakan pendekatan kualitatif yang bersifat deskriptif. Teknik pengumpulan data dengan menggunakan observasi, wawancara, dan dokumentasi. Data yang terkumpul kemudian dianalisis dengan teknik analisi dan interaktif dengan tahapan reduksi data, penyajian data, dan penarikan simpulan.

Hasil penelitian dan pembahasan menunjukan, ada tiga tahapan pembelajaran yaitu, (1) perencanaan meliputi persiapan materi lagu, mendata siswa, dan menyiapkan alat bantu pembelajaran, (2) pelaksanaan meliputi bentuk latihan antara lain pemanasan, sikap tubuh, pernapasan, artikulasi, intonasi, membaca notasi dan syair lagu, frasering, intrepretasi dan pembawaan lagu, keterpaduan, keseimbangan, (3) evaluasi meliputi tanya jawab dari kesulitan yang dihadapi siswa, penilaian di setiap akhir semester. Faktor-faktor yang mempengaruhi ekstrakurikuler paduan suara yaitu faktor pendukung dan penghambat. Faktor pendukung yaitu, (1) siswa memiliki kerjasama yang baik antar anggota, minat siswa dalam mengikuti ekstrakurikuler, dorongan diri siswa untuk meraih prestasi (2) pelatih memiliki sikap profesional yang tinggi, disiplin dan tegas, mampu menumbuhkan semangat dan percaya diri siswa, mampu mendekatkan diri dengan siswa. (3) sekolah menyediakan sarana dan prasana. Sedangkan faktor penghambat ekstrakurikuler minimnya kemampuan siswa membaca notasi angka, kurangnya rasa percaya diri dalam bernyanyi dan kurangnya kedisiplinan dalam mengikuti pembelajaran.

Saran yang dapat diberikan peneliti adalah siswa harus lebih percaya diri dalam bernyanyi dan disiplin dalam mengikuti pembelajaran, hendaknya pelatih terus menambah wawasan yang luas tentang musik terutama yang menyangkut dalam bidang olah vokal, dalam proses pembelajaran lebih di tingkatkan lagi kreativitasnya, bagi sekolah diharapkan agar terus menjaga eksistensinya dalam mengembangkan ekstrakurikuler paduan suara, bagi sekolah lain dapat menjadi referensi dalam pembelajaran paduan suara.
\end{abstract}




\section{DAFTAR ISI}

Halaman

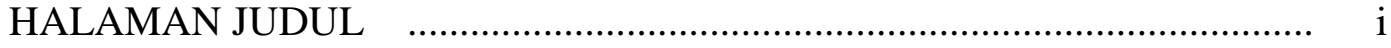

LEMBAR PENGESAHAN ................................................................... ii

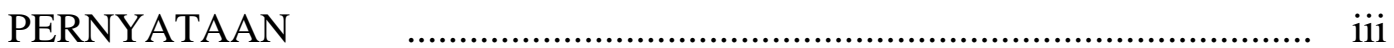

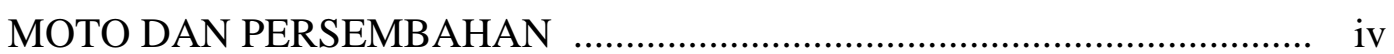

KATA PENGANTAR ..........................................................................

ABSTRAK

DAFTAR ISI

DAFTAR GAMBAR ….................................................................. viii

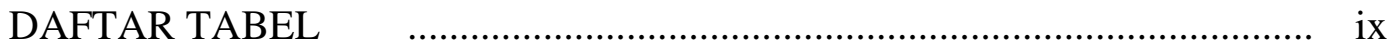

\section{BAB 1 PENDAHULUAN}

1.1. Latar Belakang Masalah ..................................................................... 1

1.2. Rumusan Masalah.............................................................................. 4

1.3. Tujuan Penelitian ............................................................................. 4

1.4. Manfaat Penelitian ..................................................................................... 4

1.4.1. Manfaat Teoritis .................................................................................... 4

1.4.2. Manfaat Praktis $\quad$........................................................................... 5

1.5. Sistematika Penulisan ...................................................................... 5

1.5.1. Bagian Awal ................................................................................ 5

1.5.2. Bagian Pokok $\quad$ ….......................................................................... 5

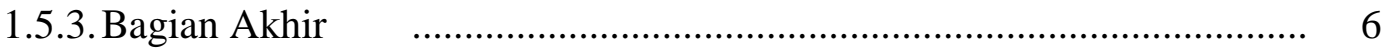

\section{BAB II LANDASAN TEORI}

$2.1 \quad$ Kajian Pustaka ................................................................................ 7

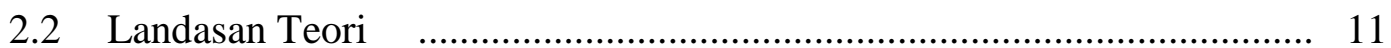

2.2.1 Pengertian Pembelajaran ................................................................. 11

2.2.2 Komponen-komponen Pembelajaran ................................................. 13

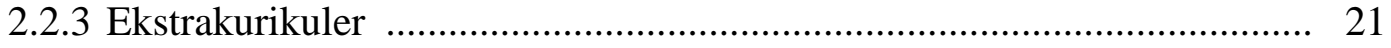




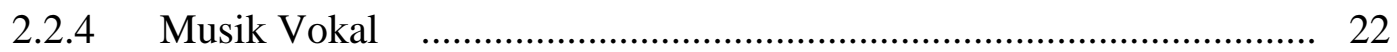

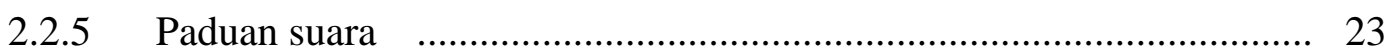

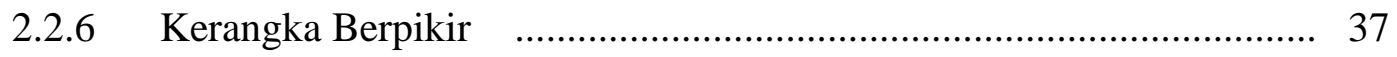

\section{BAB III METODE PENELITIAN}

3.1 Lokasi dan Sasaran Penelitian ….................................................... 40

3.1.1 Lokasi Penelitian........................................................................ 40

3.1.2 Sasaran Penelitian .......................................................................... 40

3.2 Teknik Pengumpulan Data.......................................................... 41

3.2.1 Metode Observasi .................................................................... 41

3.2.2 Metode Wawancara .................................................................... 42

3.2.3 Metode Dokumentasi ................................................................... 44

3.2.4 Teknik Pemeriksaan Keabsahan Data................................................ 46

3.3 Teknik Analisis Data .................................................................... 47

3.3.1 Redukasi Data (Penyederhanaan) f.................................................. 48

3.3.2 Penyajian Data ........................................................................ 49

3.3.3 Proses Verifikasi/ Penarikan Kesimpulan ........................................ 49

\section{BAB IV HASIL PENELITIAN DAN PEMBAHASAN}

4.1 Gambaran Umum............................................................... 51

4.1.1 Letak Geografis SMP Negeri 2 Semarang ..................................... 51

4.1.2 Terbentuknya Paduan Suara SMP Negeri 2 Semarang...................... 52

4.1.3 Prestasi Ekstrakurikuler Paduan Suara SMP Negeri 2

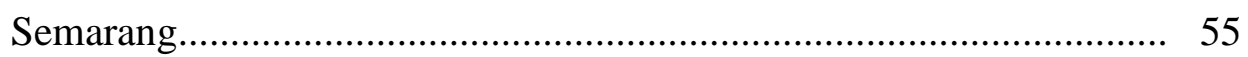

4.2 Proses Pembelajaran Ekstrakurikuler Paduan Suara SMP Negeri 2

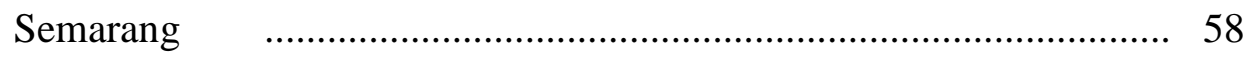

4.2.1 Tahap Perencanaan …............................................................. 58

4.2.2 Tahap Pelaksanaan ..................................................................... 62

4.2.3 Tahap Evaluasi ........................................................................... 85

4.3 Komponen-komponen Pembelajaran ........................................... 89

4.3.1 Komponen Tujuan .................................................................. 90

4.3.2 Komponen Siswa (Anggota Paduan Suara) .................................... 91

4.3.3 Komponen Guru/ Pelatih Ekstrakurikuler Paduan Suara .................... 93 
4.3.4 Komponen Metode Pembelajaran .................................................. 95

4.3.5 Komponen Alat Bantu ................................................................ 100

4.3.6 Interaksi Antara Pelatih dan Siswa ..................................................... 101

4.4 Faktor Pendukung dan Penghambat ................................................. 102

4.4.1 Faktor Pendukung Ekstrakurikuler Paduan Suara SMP

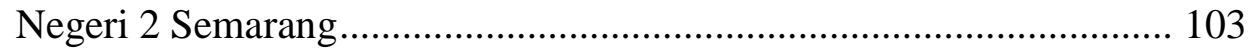

4.4.2 Faktor Penghambat Kegiatan Ektrakurikuler Paduan Suara di SMP Negeri 2 Semarang.............................................................. 106

\section{BAB V PENUTUP}

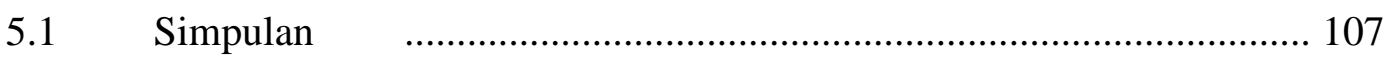

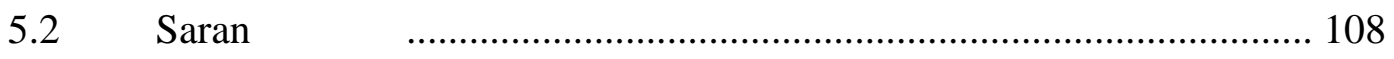

\section{DAFTAR PUSTAKA}

\section{LAMPIRAN}




\section{DAFTAR GAMBAR}

Gambar $1 \quad$ Skema Kerangka Berpikir ................................................... 38

Gambar 2 Skema Analisis Data kualitatif .......................................... 48

Gambar $3 \quad$ SMP Negeri 2 Semarang ….............................................. 52

Gambar $4 \quad$ Logo Ekstrakurikuler Paduan Suara ..................................... 54

Gambar 5 Penerimaan Piala Bergilir Sebagai Juara Umum Nasional Choir

Festival

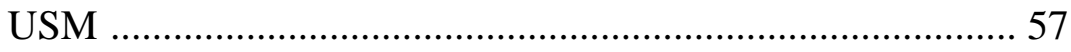

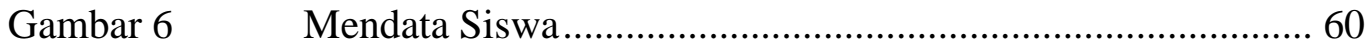

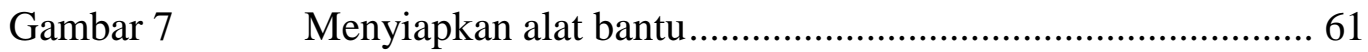

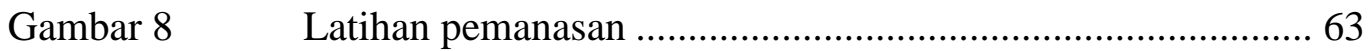

Gambar 9 Sikap Tubuh Dalam Bernyanyi .............................................. 65

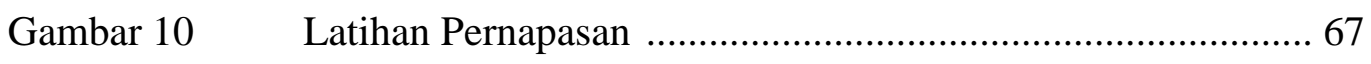

Gambar 11 Peragaan Artikulasi Huruf Vokal ....................................... 70

Gambar 12 Latihan Vokalisi Notasi Untuk Melatih Intonasi .................. 73

Gambar 13 Latihan Membaca Notasi Sesuai Dengan Kelompok Suara

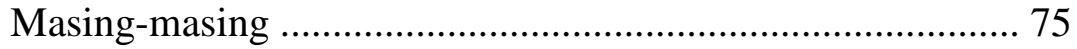

Gambar 14 Latihan Membaca Notasi dan Syair Lagu ............................ 76

Gambar 15 Siswa Anggota Paduan Suara ............................................... 92

Gambar 16 Sudaryono S.Pd, Pelatih Paduan Suara................................. 94

Gambar 17 Alat Bantu Keyboard ....................................................... 101 
DAFTAR TABEL

Tabel 1

Pedoman Penilaian Unjuk Kerja.

87 


\section{BAB I}

\section{PENDAHULUAN}

\subsection{Latar Belakang Masalah}

Dewasa ini berbagai jenis kesenian mulai ditampilkan sebagai hiburan maupun sebagai edukasi. Adanya beragam hiburan, masyarakat dapat mengenal berbagai macam kesenian. Tidak hanya berfungsi sebagai hiburan, kesenian juga dikembangkan dalam pendidikan di sekolah. Pendidikan seni atau yang disebut seni budaya merupakan mata pelajaran kesenian yang telah tercantum didalam kurikulum sekolah, yang termasuk didalamnya pendidikan musik. Pendidikan seni musik formal disekolah, selain sebagai mata pelajaran yang tercantum didalam kurikulum juga dapat diberikan melalui kegiatan ekstrakurikuler. Ekstrakurikuler lebih mengutamakan materi yang tidak atau belum terjangkau dalam kurikulum sekolah.

Prestasi yang telah berhasil dicetak oleh sekolah merupakan salah satu hal yang dapat mempengaruhi kelangsungan penyelenggaraan suatu kegiatan ekstrakurikuler. Hal tersebut dapat memotivasi siswa untuk mengikuti pembelajaran ekstrakurikuler. Selain itu dipengaruhi pula oleh keinginan untuk mengembangkan bakat dalam bidang seni. Hal tersebut dapat diperkuat dengan penelitian yang dilakukan oleh Yudi Tezar Aditiyas pada tahun 2008 yang berjudul, Pembelajaran Ekstrakurikuler Ansambel Gesek Di SMA Negeri 03 Semarang'. Menyatakan bahwa kegiatan ekstrakurikuler ansambel gesek yang diadakan di sekolah dengan tujuan memberikan pengalaman pengetahuan 
bermusik dan menumbuhkan sikap siswa yang positif seperti, mengembangkan daya kreatif, motivasi, dan sikap mereka untuk mempelajari sesuatu yang akan menimbulkan minat yang baik. Muchammad Fais Noor Khamim dalam skripsinya tahun 2011, "Pembelajaran Ekstrakurikuler Rebana Terbang Zipin Di Madrasah Aliyah Negeri 01 Kabupaten Kudus". Menyatakan bahwa prestasi yang diraih MAN $01 \mathrm{Kab}$ Kudus memberikan pengaruh besar terhadap peserta didik untuk lebih meningkatkan aktivitas rebana dengan cara mengikuti kegiatan ekstrakurikuler dalam rangka mempertahankan prestasi yang telah diraih.

Dari kedua penelitian tersebut, dapat disimpulkan bahwa kegiatan ekstrakurikuler mempunyai manfaat yang positif bagi siswa, antara lain siswa dapat meraih dan mempertahankan prestasi, serta mengembangkan kreatifitas siswa. Kegiatan ekstrakurikuler ini juga menampung minat siswa untuk meningkatkan kualitas di bidang kesenian. Demikian pula sama halnya dengan pembelajaran esktrakurikuler Paduan suara di SMP Negeri 2 Semarang.

Pembelajaran paduan suara di SMP Negeri 2 Semarang merupakan salah satu kegiatan ekstrakurikuler dalam bidang kesenian sebagai media pengembangan keterampilan, minat dan bakat setiap siswa dalam bidang seni khususnya olah vokal. Banyak prestasi yang diraih oleh paduan suara SMP Negeri 2 antara lain; Juara 1 Lomba Paduan Suara Universitas Semarang tingkat Nasional tahun 2010, medali Perak Satya Dharma Gita National Choir Festival tahun 2013, Juara 1 Lomba Paduan Suara se-Kota Semarang tahun 2013, juara 2 Lomba Paduan Suara se-Jawa Tengah dan DIY tahun 2013, Juara Paduan Suara tingkat Jawa Tengah tahun 2006, diselenggarakan oleh USM, Juara Paduan Suara tingkat 
Jawa Tengah tahun 2008 diselenggarakan oleh USM, Medali Perak Paduan Suara tingkat Nasional tahun 2008 diselenggarakan oleh ITB, Medali Perak Paduan Suara tingkat Nasional tahun 2010 diselenggarkan oleh ITB, Juara 2 Lomba Paduan Suara Nasionalisme tingkat Provinsi, Medali Perak Nasional Choir Competation UNDIP 2013, Medali Perak Nasional Choir Competation UNDIP 2015 dan Medali Emas Nasional Choir Festival USM 2015.

Minat siswa dalam mengikuti ekstrakurikuler paduan suara ini pun cukup tinggi, dilihat dari banyaknya jumlah peserta yang mengikuti ekstrakurikuler paduan suara di SMP Negeri 2 Semarang. Melalui paduan suara, dapat mengasah keterampilan siswa dalam berolah vokal serta dapat melatih kedisiplinan, percaya diri, kerjasama serta tanggung jawab. Prestasi yang diraih tentu karena adanya dukungan dan partisipasi aktif dari semua pihak yang terlibat di dalamnya dan faktor terpenting yang mempengaruhi prestasi karena adanya proses pembelajaran paduan suara yang baik dengan metode tepat yang terapkan oleh pelatih. Seperti halnya dengan penelitian Cindy MDA (2013) yang berjudul "Meningkatkan Kemampuan Bernyanyi dalam Kegiatan Ekstrakurikuler Paduan Suara Melalui Implementasi Metode Pendekatan Kognitif di SMA Negeri Banyumas”, dengan diterapkannya metode pendekatan kognitif dapat meningkatkan kemampuan bernyanyi siswa dalam kegitan ekstrakurikuler paduan suara. Metode pendekatan kognitif yang diterapkan sangat berpengaruh terhadap kualitas paduan suara, dengan kualitas yang baik tidak menutup kemungkinan dapat menghasilkan banyak prestasi. 
Berdasarkan latar belakang yang ada serta karena prestasi yang telah diperoleh paduan suara SMP Negeri 2 Semarang, peneliti merasa tertarik untuk meneliti proses pembelajaran ekstrakulikuler paduan suara di SMP Negeri 2 Semarang, dan mencari tahu apa saja faktor yang mempengaruhi ekstrakurikuler paduan suara tersebut.

\subsection{Rumusan Masalah}

Berdasarkan latar belakang, pokok pembahasan dalam penelitian ini adalah Bagaimana proses pembelajaran esktrakurikuler paduan suara di SMP Negeri 2 Semarang dan faktor-faktor yang mempengaruhinya?

\subsection{Tujuan Penelitian}

Berdasarkan rumusan masalah di atas, tujuan yang hendak dicapai dalam penelitian ini adalah mengetahui, mendiskripsikan serta menganalisis proses pembelajaran esktrakurikuler paduan suara di SMP Negeri 2 Semarang dan faktor-faktor yang mempengaruhinya?

\subsection{Manfaat Penelitian}

Penelitian ini akan dapat memberikan manfaat baik teoritis maupun praktis sebagai berikut:

\subsubsection{Manfaat Teoritis}

Hasil penelitian ini dapat digunakan sebagai; (1) kontribusi bagi kepustakaan dengan harapan dapat menjadi inspirasi dalam mengembangkan 
pembelajaran paduan suara. (2) Bagi penulis selanjutnya, dapat sebagai dasar rujukan penulisan lebih lanjut.

\subsubsection{Manfaat Praktis}

Penelitian ini memiliki 3 manfaat praktis terdiri atas; (1) Bagi peneliti dapat menambah wawasan dalam pelaksanaan pembelajaran bidang vokal khususnya paduan suara. (2) Bagi Paduan Suara SMP Negeri 2 Semarang dapat menjadi gambaran atau deskripsi tertulis tentang pembelajaran paduan suara yang digunakan di Paduan Suara SMP Negeri 2 Semarang. (3) Bagi masyarakat, penelitian ini diharapkan dapat memberikan informasi yang bermanfaat mengenai paduan suara.

\subsection{Sistematika Penulisan}

Sistematika skripsi bertujuan untuk memberikan gambaran serta mempermudah pembaca dalam mengetahui garis-garis besar dari skripsi ini, yang berisi sebagai berikut; (1) bagian awal, (2) bagian pokok, dan (3) bagian akhir.

\subsubsection{Bagian Awal}

Bagian awal skripsi terdiri atas lembar judul, lembar persetujuan dosen pembimbing, lembar pernyataan, lembar motto dan persembahan, kata pengantar, lembar abstrak, daftar isi, daftar gambar dan daftar tabel, dan daftar lampiran.

\subsubsection{Bagian Pokok}

Bagian pokok skripsi terdiri atas; (1) pendahuluan, (2) landasan teori, (3) metode penelitian, (4) hasil penelitian dan pembahasan, dan (5) penutup. Bab 1 
Pendahuluan, pada bab ini diuraikan mengenai latar belakang masalah, rumusan masalah, tujuan penelitian, manfaat penelitian, dan sistematika skripsi. Bab 2 Landasan Teori, pada bab ini memuat landasan teori yang berisi kajian pustaka yang berhubungan dengan masalah-masalah yang dibahas dalam penelitian ini

meliputi; (1) pengertian pembelajaran, (2) komponen pembelajaran, (3) ekstrakurikuler, (4) musik vokal, (5) paduan suara. Bab 3 Metode Penelitian, pada bab ini terdiri dari hal-hal yang berhubungan dengan prosedur penelitian yang meliputi: lokasi dan sasaran penelitian, teknik pengumpulan data, teknik pemerikasaan keabsahan data, teknik analisis data. Bab 4 Hasil Penelitian dan pembahasan, pada bab ini memuat data-data yang diperoleh sebagai hasil dari penelitian dan dibahas secara deskriptif kualitatif yang terdiri atas; (1) gambaran umum penelitian mengenai SMP Negeri 2 Semarang dan (2) kegiatan ekstrakurikuler paduan suara. Bab 5 Penutup, Bab ini merupakan bab terakhir yang memuat simpulan dan saran.

\subsubsection{Bagian Akhir}

Bagian akhir terdiri atas daftar pustaka dan lampiran-lampiran antara lain: pedoman observasi, pedoman wawancara, pedoman dokumentasi, surat ijin penelitian dan surat keterangan telah melaksanakan penelitian, lampiran. 


\section{BAB II}

\section{LANDASAN TEORI}

\subsection{Kajian Pustaka}

Dalam penulisan skripsi ini peneliti menggali informasi dari penelitianpenelitian sebelumnya sabagai bahan perbandingan. Baik mengenai kekurangan atau kelebihan yang sudah ada dalam rangka mendapatkan suatu informasi yang ada sebelumnya tentang teori yang berkaitan dengan judul yang digunakan untuk memperoleh landasan teori ilmiah.

Peneliti Cindy MDA (2013) yang berjudul "Meningkatkan Kemampuan Bernyanyi dalam Kegiatan Ekstrakurikuler Paduan Suara Melalui Implementasi Metode Pendekatan Kognitif di SMA Negeri Banyumas”, dilatarbelakangi oleh rendahnya kemampuan bernyanyi siswa yang mengikuti kegiatan ekstrakurikuler paduan suara. Untuk itu diperlukan penerapan metode pembelajaran yang tepat. Dengan diterapkan metode pendekatan kognitif sebagai metode pembelajaran diharapkan dapat meningkatkan kemampuan bernyanyi siswa dalam paduan suara. Penelitian kajian pustaka ini bertujuan untuk mengetahui, mendeskripsikan, dan menganalisis peningkatan kemampuan bernyanyi dalam kegiatan ekstrakurikuler paduan suara dengan menerapkan metode pendekatan kognitif di SMA Negeri Banyumas. Jenis Penelitian yang digunakan adalah Tindakan Kelas (PTK) yang terbagi ke dalam dua siklus. Masing-masing siklus dilakukan dengan tahapan perencanaan, tindakan, observasi, dan refleksi. Variabel penelitian yang digunakan adalah variable input, variabel proses dan variabel output. Teknik 
pengumpulan data dilakukan melalui observasi, wawancara, dokumentasi, dan teknik penilaian. Teknik analisis data yang digunakan pada penelitian ini adalah analisis secara kualitatif dan kuantitatif.

Hasil penelitian menunjukkan bahwa penerapan metode pendekatan kognitif dapat meningkatkan kemampuan bernyanyi siswa dalam kegiatan ekstrakurikuler paduan suara. Berdasarkan hasil penilaian siklus I hanya $60 \%$ siswa yang mencapai kategori nilai baik dan sangat baik (>70) kemudian meningkat pada siklus II dapat mencapai indikator keberhasilan yakni sebanyak $80 \%$ siswa sudah mencapai nilai dengan kategori baik dan sangat baik (>70). Berdasarkan hasil penelitian tersebut, disarankan agar metode pendekatan kognitif dapat diterapkan dalam pembelajaran paduan suara oleh guru/ pelatih ekstrakurikuler paduan suara baik di sekolah ini maupun di sekolah lain, rutinitas latihan paduan suara harus dilakukan secara teratur dan lebih efisien.

Peneliti Anita Aryanti (2013) yang berjudul “Upaya Meningkatkan Teknik Vokal Pada Paduan Suara Inovatif Dengan Menggunakan Metode Imitasi Dan Drill”, dilatar belakangi oleh rendahnya tingkat penguasaan teknik vokal paduan suara inovatif. Penelitian ini bertujuan untuk meningkatkan teknik vokal paduan suara inovatif dengan menggunakan metode imitasi dan drill. Penelitian ini merupakan penelitian tindakan yang terdiri atas dua siklus. Subjek penelitian ini adalah kelompok paduan suara inovatif yang berjumlah 24 anggota. Teknik pengumpulan data yang digunakan adalah teknik tes. Teknik analisis data dalam penelitian ini menggunakan deskriptif kualitatif. Intrumen penelitian yang digunakan adalah lembar penilaian kriteria yang terdiri dari 6 aspek pengukuran. 
Untuk mengetahui tingkat validitas instrumen, digunakan face validity dengan menggunakan experts judgement.

Hasil penelitian menunjukkan bahwa ada peningkatan teknik vokal paduan suara inovatif dengan menggunakan metode imitasi dan drill. Hal ini dilihat dari peningkatan rata-rata kelas sebelum dan sesudah diberikan tindakan. Untuk mengukur tingkat keberhasilan vokal anggota paduan suara, maka dilakukan evaluasi yaitu praktik bernyanyi yang dilakukan pada setiap akhir siklus yaitu anggota paduan suara melakukan teknik vokal dengan benar sesuai dengan yang diharapkan. Peningkatan teknik vokal dapat dilihat dari hasil tes yang dilakukan pada setiap akhir siklus, dan terjadi peningkatan dari siklus I ke siklus II. Berikut nilai rata-rata hasil evaluasi/ tes penilaian teknik vokal paduan suara yang diperoleh. Rata-rata nilai pra siklus adalah 61.82, siklus I adalah 75.26, dan siklus II adalah 86,35. Berdasarkan hasil nilai rata-rata, dapat disimpulkan bahwa penggunaan metode imitasi dan drill dapat meningkatkan teknik vokal paduan suara inovatif.

Dari dua kajian pustaka tersebut merupakan penelitian tindakan kelas atau PTK yang terdiri atas dua siklus. Penelitian tersebut lebih menekankan pada penerapan suatu metode pada kelompok paduan suara guna meningkatkan kualititas dalam paduan suara tersebut, seperti teknik bernyanyi dan kemampuan dalam bernyanyi. Teknik pengumpulan data yang digunakan adalah teknik tes. Penelitian kajian ini menggunakan deskriptif kualitatif. Dengan adanya metode yang diterapkan apakah mampu atau berpengaruh terhadap peningkatan teknik benyanyi pada paduan suara. 
Sedangkan dalam penelitian ini, yang berjudul "Pembelajaran Ekstrakurikuler Paduan Suara Di SMP Negeri 2 Semarang” lebih menekankan pada proses pembelajaran paduan suara disuatu sekolah yaitu di SMP Negeri 2 Semarang, metode-metode yang digunakan serta faktor penghambat dan pendukung pembelajaran paduan suara. Penelitian ini tidak melakuan penelitian tindakan kelas yang menerapkan metode baru untuk perbandingan atau peningkatan sesuatu yang akan diteliti apakah dengan metode yang diterapkan dapat berpengaruh atau tidak dengan pembelajaran sebelummnya.

Dalam penelitian ini lebih berfokus pada "pendiskripsian" yaitu mendiskripsikan pembelajaran ekstrakurikuer paduan suara yang didalamnya mengamati proses pembelajaran, pelaksanaan pembelajaran ekstrakuikuler paduan suara seperti; metode- metode apa saja yang digunakan, teknik, materi pembelajaran yang disajikan, pengelolahan kelas, faktor pendukung dan penghambat yang ikut berpengaruh terhadap keberhasilan proses pembelajaran ekstrakurikuler paduan suara, serta evaluasi pembelajaran ekstrakurikuler paduan suara di SMP Negeri 2 Semarang. Sama halnya dengan penelitian dalam kajian pustaka, analisis penelitian ini menggunakan penelitian deskriptif kualitatif. Teknik pengumpulan data yang digunakan adalah observasi, wawancara, dokumentasi. Data yang telah terkumpul dianalisis secara deskriptif dengan tahapan; pengumpulan data, reduksi data, penyajian, dan penarikan simpulan/ verifikasi. 


\subsection{Landasan Teori}

\subsubsection{Pengertian Pembelajaran}

Pembelajaran adalah suatu kombinasi yang tersususun meliputi unsurunsur manusiawi, material, fasilitas, perlengkapan, dan prosedur yang saling mempengaruhi mencapai tujuan pembelajaran. Manusia terlibat dalam sistem pengajaran terdiri dari siswa, guru, dan tenaga lainnya, misalnya tenaga laboratorium. Material, meliputi buku-buku, papan tulis, dan kapur, fotografi, slide, dan film, audio, dan video tape. fasilitas dan perlengkapan, terdiri terdiri dari ruangan kelas, perlengkapan audio visual, juga komputer. Prosedur, meliputi jadwal dan metode penyampaian informasi, praktik, belajar, tujuan dan sebagainya, Hamalik (2008:57).

Pembelajaran menurut Briggs (dalam Tri Ani, 2012:157) adalah seperangkat peristiwa events yang mempengaruhi peserta didik sedemikian rupa sehingga peserta didik itu memperoleh kemudahan. Sementara itu, menurut Gagne (dalam Tri Ani, 2012:158) menyatakan bahwa pembelajaran merupakan sebagian peristiwa eksternal peserta didik yang dirancang untuk mendukung proses internal belajar. Peristiwa belajar ini dirancang agar memungkinkan peserta didik memproses informasi nyata dalam rangka mencapai tujuan yang telah ditetapkan.

Pembelajaran memiliki hakikat perencanaan atau perancangan (design) sebagai upaya untuk membelajarkan siswa. Itulah sebab dalam belajar, siswa tidak hanya berinteraksi dengan guru sebagai salah satu sumber belajar yang dipakai untuk mecapai tujuan pembelajaran yang diinginkan. Oleh karena itu, 
pembelajaran memusatkan perhatian pada "bagaimana membelajarkan siswa", dan bukan pada " apa yang dipelajari siswa". Adapun perhatian terhadap apa yang dipelajari siswa merupakan bidang kajian dari kurikulum, yakni mengenai apa isi pembelajaran yang harus dipelajari siswa agar tercapainya tujuan. Pembelajaran lebih menekankan pada bagaimana cara agar tercapainya tujuan tersebut. Dalam kaitan ini hal-hal yang tidak bisa dilupakan untuk mencapai tujuan adalah bagamana cara mengorganisasikan pembelajaran, bagaimana menyampaikan isi pembelajaran, dan bagaimana menata interaksi antara sumbersumber belajar yang ada agar dapat berfungsi secara optimal, Uno (2006:2-3).

Didalam pembelajaran terdapat perencanaan dan juga pelaksanaan pembelajaran. Perencanaan pembelajaran adalah menyusun langkah-langkah yang akan dilaksanakan untuk mencapai tujuan yang telah ditentukan. Proses pembelajaran selain diawali dengan perencanaan yang bijak, serta didukung dengan komunikasi yang baik, juga harus didukung dengan pengembangan strategi yang mampu membelajarkan siswa (Saputri 2013:38-39). Lebih lanjut, menurut Majid (dalam Saputri 2013:39), pelaksanaan pembelajaran merupakan proses penyelenggaraan peserta didik dengan pendidik dan sumber belajar pada suatu lingkungan belajar.

Berdasarkan pendapat para ahli mengenai pembelajaran, maka dapat ditarik kesimpulan bahwa pembelajaran adalah kegiatan yang dilakukan oleh pendidik secara sengaja dalam membantu siswa untuk belajar sesuai dengan kebutuhan dan minatnya, sehingga dalam diri siswa terjadi perubahan tingkah laku ke arah yang lebih baik dan di dapatnya kemampuan baru dari adanya proses 
belajar tersebut. Contoh perubahan tingkah laku tersebut yaitu: kepribadian, kemampuan, dan keterampilan yang terjadi karena sesuatu pengalaman belajar atau latihan. Pembahasan mengenai hakekat pembelajaran tidak akan terlepas dari pembahasan mengenai belajar dan mengajar, karena setiap proses pembelajaran terjadi peristiwa belajar dan mengajar.

\subsubsection{Komponen-Komponen Pembelajaran}

Kegiatan pembelajaran akan melibatkan pada beberapa aspek yaitu (1) materi pelajaran, (2) tujuan pembelajaran, (3) karakteristik siswa, (4) kemampuan guru dan (5) sarana atau fasilitas yang dimiliki sekolah, Suharto (dalam jurnal Harmonia, 2007).

Kemudian Djamarah (2002:48), mengatakan bahwa terdapat beberapa komponen yang mempengaruhi dalam pembelajaran yang meliputi: tujuan pembelajaran, materi pembelajaran, pendidik, siswa, metode, evaluasi, dan alat (sarana dan prasarana). Komponen-komponen tersebut sebagai berikut:

\subsubsection{Tujuan pembelajaran}

Tujuan adalah suatu cita-cita yang ingin dicapai dari pelaksanaan suatu pembelajaran. Tidak ada suatu pembelajaran yang diprogramkan tanpa tujuan, karena hal ini merupakan kegiatan yang memiliki kepastian dalam menentukan arah, target dan prosedur yang dilakukan. Tujuan dalam pendidikan dan pengajaran merupakan suatu cita-cita yang bernilai normatif. Sebab dalam tujuan terdapat sejumlah nilai yang harus ditanamkan kepada anak didik. Nilai-nilai itu 
nantinya akan mewarnai cara anak didik bersikap dan berbuat dalam lingkungan sosial, baik di sekolah maupun di luar sekolah, Fathurrohman (2007:13).

Tujuan pembelajaran merupakan bagian integral dari sistem pembelajaran, merupakan suatu deskripsi tingkah laku yang diharapkan tercapai oleh siswa, dan oleh karenanya perlu dipelajari oleh setiap guru. Tujuan belajar terdiri dari komponen-komponen tingkah laku terminal, kondisi-kondisi tes, dan ukuran perilaku. Tujuan penting untuk menilai hasil pembelajaran, membimbing siswa belajar, merancang siswa pembelajaran, bahkan dapat digunakan sebagai instrumen pengukuran. Tujuan pembelajaran hendaknya memenuhi kriteria kondisi untuk belajar, rumusan tingkah laku, dan ukuran minimal tingkah laku yang diinginkan, Hamalik (2008:83).

\subsubsection{Materi Pelajaran}

Materi pelajaran juga merupakan komponen utama dalam proses pembelajaran, karena materi pelajaran akan memberi warna dan bentuk dari kegiatan pembelajaran. Materi pelajaran yang komprehensif, terorganisasi secara sistematis dan dideskripsikan dengan jelas akan berpengaruh juga terhadap intensitas proses pembelajaran. Materi pelajaran dalam sistem pembelajaran berada dalam Silabus, Rencana Pelaksanaan Pembelajaran (RPP), dan buku sumber. Maka pendidikan hendaknya dapat memilih dan mengorganisasikan materi pelajaran agar proes pembelajaran dapat berlangsung intensif, Tri Ani (2012:160).

Materi pengajaran adalah subtansi yang akan disampaikan dalam proses pembelajaran. Tanpa materi pengajaran, proses pembelajaran tidak akan berjalan. 
Karena itu, guru yang akan mengajar pasti memiliki dan menguasai materi pelajaran yang akan disampaikannya kepada anak didik, Djamarah (2002:50).

Bahan/ materi merupakan medium untuk mencapai tujuan pengajaran yang “dikonsumsi' oleh peserta didik. Bahan ajar merupakan materi yang terus berkembang secara dinamis seiring dengan kemajuan dan tuntutan perkembangan masyarakat. Bahan ajar yang di terima anak didik harus mampu merespons setiap perubahan dan mengantisipasi setiap perkembangan yang akan terjadi di masa depan, Fathurrohman $(2007: 14)$

\subsubsection{Pendidik/ Guru}

Pendidik merupakan suatu komponen yang penting dalam penyelenggaraan pendidikan, yang bertugas menyelenggarakan kegiatan mengajar, melatih, meneliti, mengembangkan, mengelola, dan atau memberikan pelayanan teknis dalam bidang pendidikan. Salah satu unsur tenaga kependidikan adalah tenaga pendidik/ tenaga pengajar yang tugas utamanya adalah mengajar, Hamalik (2008:9). Guru sendiri adalah sumber utama tujuan bagi para siswa, dan dia harus mampu menulis dan memilih tujuan-tujuan pendidikan yang bermakna, dan dapat terukur, Hamalik (2008:76).

Guru perlu memiliki kemampuan dalam proses pembelajaran, di samping kemampuan kepribadian dan kemampuan kemasyaraatan. Kemampuan dalam proses pembelajaran sering disebut kemampuan profesional. Guru perlu berupaya meningkatkan kemampuan-kemampuan tersebut agar senantiasa beda dalam kondisi siap untuk membelajarkan siswa, Hamalik (2008:67). Guru adalah tenaga profesional yang membuat perencanaan dan melaksanakan pembelajaran; menilai 
hasil pembelajaran; memberikan bimbingan dan pelatihan kepada peserta didik. Di samping itu, sebutan guru dikhususkan bagi para pendidik yang bertugas pada jenjang pendidikan usia dini sampai dengan jenjang pendidikan menengah, Sutirman (2013:1).

Pekerjaan guru merupakan suatu profesi, karena guru mempunyai kedudukan sebagai tenaga profesional. Profesional merupakan pekejaan atau kegiatan yang dilakukan oleh seseorang dan menjadi sumber penghasilan kehidupan yang memerlukan keahlian kemahiran, atau kecakapan yang memenuhi standar mutu atau norma tertentu serta memerlukan pendidikan profesi. Dengan demikian guru memiliki karakteristik sebagai suatu pekerjaan yang menjadi sumber penghasilan; memerlukan keahlian, kemahiran, dan kecakapan tertentu; memilki sandar mutu dan norma; serta memerlukan pendidikan profesi, Sutirman $(2013: 2)$.

Kompetensi guru sebagai suatu kecakapan, daya (kemampaun), otoritas (kewenangan), kemahiran, ketrampilan, pengetahuan, dan lain-lain berdasarkan kriteria, kondisi, dan konteks profesi merupakan persyaratan yang harus dimiliki oleh semua guru termasuk guru seni musik, Utomo ( dalam jurnal Harmonia, 2013:111).

\subsubsection{Siswa}

Siswa/ peserta didik merupakan suatu komponen masukan dalam sistem pendidikan, yang selanjutnya diproses dalam proses pendidikan, sehingga menjadi manusia yang berkualitas sesuai dengan tujuan pendidikan nasional, Hamalik (2008:7). Sementara itu, menurut Tri Ani (2012:160) subyek belajar dalam sistem 
pembelajaran merupakan komponen utama karena berperan sebagai subyek sekaligus obyek. Sebagai subyek karena peserta didik adalah individu yang melakukan proses belajar-mengajar. Sebagai obyek karena kegiatan pembelajaran diharapkan dapat mencapai perubahan perilaku pada diri subyek belajar. Untuk itu dari pihak peserta didik diperlukan partisipasi aktif dalam kegiatan pembelajaran. Partisipasi aktif subyek belajar dalam proses pembelajaan antara lain di pengaruhi faktor kemampuan yang telah dimiliki hubungannya dengan materi yang akan dipelajari, oleh karena itu untuk kepentingan perencanaaan pembelajaran yang efektif diperlukan pengetahuan pendidik tentang diagnosis kesulitan belajar dan analisis tugas.

\subsubsection{Metode}

Metode dalam kegiatan belajar mengajar menurut Djamarah (dalam jurnal Harmonia Sulasmono, 2013:47) adalah seperangkat upaya yang dilaksanakan dan disusun dengan tujuan menciptakan suasana belajar mengajar yang menguntungkan. Lebih lanjut, menurut Fathurrohman (2007: 15), penentuan metode yang digunakan oleh guru dalam proses pembelajaran akan sangat menentukan berhasil atau tidaknya pembelajaran yang berlangsung, dalam kegiatan belajar mengajar, metode sangat diperlukan oleh guru, dengan penggunaan yang bervariasi sesuai dengan tujuan yang ingin dicapai. Menguasai metode mengajar merupakan keniscayaan, sebab seorang guru tidak akan dapat mengajar dengan baik apabila ia tidak menguasai metode secara tepat.

Menurut Djamarah (1996:53) metode adalah suatu cara yang dipergunakan untuk mencapai tujuan yang telah ditetapkan. Dalam kegiatan belajar mengajar, 
metode diperlukan oleh guru dan penggunaanya bervariasi sesuai dengan tujuan yang ingin dicapai setelah pengajaran berakhir. Seorang guru tidak dapat melaksanakan tugasnya bila dia tidak menguasai satu pun metode mengajar yang telah dirumuskan dan dikemukakan para ahli psikologi dan pendidikan.

Dalam kegiatan belajar mengajar, guru tidak harus terpaku dengan menggunakan satu metode, tetapi guru sebaiknya menggunakan metode bervariasi agar jalannya pengajaran tidak membosankan, tetapi menarik perhatian anak didik. Tetapi juga penggunaan metode yang bervariasi tidak akan menguntungkan kegiatan belajar mengajar bila penggunaannya tidak tepat dan sesuai dengan situasi yang mendukungnya dan dengan kondisi psikologis anak didik. Oleh karena itu, disinilah kompetensi guru diperlukan dalam pemilihan metode yang tepat. Oleh karena itu, pemilihan dan penggunaan metode yang bervariasi tidak selamanya menguntungkan bila guru mengabaikan faktor-faktor yang mempengaruhi penggunaanya, Djamarah (1996:53). Prof. Dr. Winarno Surakhmad mengemukakan (dalam Djamarah, 1996:53) ada lima maca faktor yang mempengaruhi penggunaan metode mengajar sebagai berikut: (1) Tujuan yang berbagai-bagai jenis dan fungsinya. (2) Anak didik yang berbagai-bagai tingkat kematangannya. (3) Situasi yang berbagai-bagai keadaannya. (4) Fasilitas yang berbagai-bagai kualitas dan kuantitasnya. (5) Pribadi guru serta kemampuan profesionalnya yang berbeda-beda.

\subsubsection{Alat}

Alat yang digunakan dalam pembelajaran merupakan segala sesuatu yang dapat digunakan dalam rangka mencapai tujuan pembelajaran. Dalam proses 
pembelajaran alat memiliki fungsi sebagai pelengkap untuk mencapai tujuan. Alat dapat dibedakan menjadi dua, yaitu alat verbal dan alat bantu nonverbal. Alat verbal dapat berupa suruhan, perintah, larangan, dan lain-lain, sedangkan yang non verbal dapat berupa globe, peta, papan tulis slide dan lain-lain, Suharto (2015 $: 12)$.

Menurut Fathurrohman (2007:15), Jika dilihat dari sisi asalnya, alat terbagi atas alat material dan non material. Menurut Dwyer (dalam Fathurrohman, 2007:15) berpendapat bahwa belajar yang sempurna hanya dapat tercapai jika menggunakan bahan-bahan audio-visual yang mendekati realitas. Melalui alat bantu pengajaran yang tepat, diharapkan guru dapat memberikan pengalaman belajar yang banyak dengan cara sedikit.

Menurut Djamarah (1996:55), sebagai alat bantu dalam pendidikan dan pengajaran, alat material (audiovisual) mempunyai sifat sebagai berikut: (1) kemampuan untuk meningkatkan persepsi. (2) kemampuan untuk meningkatkan kemampuan. (3) kemampuan untuk meningkatkan transfer/ pengalihan belajar. (4) kemampuan untuk memberikan penguatan atau pengetahuan hasil yang dicapai. (5) kemampuan untuk meningkatkan retensi/ ingatan.

\subsubsection{Evaluasi}

Komponen evaluasi adalah komponen yang berfungsi untuk mengetahui apakah tujuan yang telah ditetapkan telah tercapai atau belum, juga bisa berfungsi sebagai umpan balik untuk perbaikan strategi yang telah ditetapkan, Suharto (2015:13). Menurut Fathurrohman (2007:14-15), evaluasi memiliki tujuan secara umum, yakni: (1) Mengumpulkan data-data yang membuktikan taraf kemajuan 
murid dalam mencapai tujuan yang diharapkan. (2) Memungkinkan pendidik/ guru menilai aktivitas/ pengalaman yang didapat siswa dalam pembelajaran. (3) Menilai metode mengajar yang dipergunakan.

Evaluasi pembelajaran merupakan suatu proses untuk menentukan jasa, nilai atau manfaat kegiatan pembelajaran melalui kegiatan penilaian dan/ atau pengukuran. Evaluasi pembelajaran mencakup pembuatan pertimbangan tentang jasa, nilai atau manfaat program, hasil, dan proses pembelajaran, Dimyati (2006: 221). Pelaksanaan evaluasi diarahkan kepada evaluasi proses dan evaluasi produk. Evaluasi proses dimaksud, adalah suatu evaluasi yang diarahkan untuk menilai bagaimana pelaksanaan proses belajar mengajar yang telah dilakukan mencapai tujuan, apakah dalam proses itu ditemui kendala, dan bagaimana kerja sama setiap komponen pengajaran yang telah diprogramkan dalam suatu pelajaran. Evaluasi produk yang dimaksud, adalah suatu evaluasi yang diarahkan kepada bagaimana hasil belajar yang telah dilakukan oleh siswa, dan bagaimana penguasaan siswa terhadap bahan/ materi pelajaran yang telah guru berikan ketika proses belajar mengajar berlangsung, Winkel (dalam Djamarah, 1996:59).

Menurut Djamarah (1996:59-60), ketika evaluasi dapat memberikan manfaat bagi guru dan siswa, maka evaluasi mempunyai fungsi sebagai berikut : (1) Untuk memberikan umpan balik (feed back) kepada guru sebagai dasar untuk memperbaiki proses belajar mengajar, serta mengadakan perbaikan program bagi murid.

(2) Untuk memberikan angka yang tepat tentang kemajuan atau hasil belajar dari setiap murid. Antara lain digunakan dalam rangka pemberian laporan kemajuan 
belajar murid kepada orang tua, penentuan kenaikan kelas, serta penentuan lulus tidaknya seorang murid.

(3) Untuk menentukan murid didalam situasi belajar mengajar yang tepat, sesuai dengan tingkat kemampuan dan karakteristik lainnya dimiliki oleh murid.

(4) Untuk mengenal latar belakang (psikologis, fisik dan lingkungan) murid yang mengalami kesulitan-kesulitan belajar, nantinya dapat dipergunakan sebagai dasar dalam pemecahan kesulitan-kesulitan belajar yang timbul.

\subsubsection{Ekstrakurikuler}

\subsubsection{Pengertian Ekstrakurikuler}

Kegiatan ekstrakurikuler adalah kegiatan yang dilakukan di luar jam pelajaran tatap muka dilaksanakan di sekolah atau di luar sekolah untuk memperkaya dan memperluas wawasan pengetahuan atau kemampuan peningkatan nilai atau sikap dalam rangka menerapkan pengetahuan dan kemampuan yang telah dipelajari dari berbagai mata pelajaran dalam kurikulum menurut pedoman, Depdikbud (1990: 11).

Kegiatan ekstrakurikuler terutama diluar mata pelajaran ditujukan untuk mengasah bakat dan prestasi siswa dan tidak untuk dinilai. Apabila pembimbing perlu mengadakan penilaian hanya sebatas pada penguatan bakat dan prestasi siswa, Ichsan (1991:224). Kegiatan ektrakurikuler dimaksudkan untuk memperluas pengetahuan siswa mengenal hubungan antara berbagai mata pelajaran atau bidang pengetahuan, menyalurkan bakat/ minat yang menunjang pencapaian tujuan intruksional serta melengkapi upaya-upaya pembinaan manusia seutuhnya, kegiatan secara berkala pada waktu tertentu, Djamarah (2000:216). 


\subsubsection{Tujuan Ekstrakurikuler}

Menurut pedoman Depdikbud (1994:11), dinyatakan bahwa tujuan ekstrakulikuler adalah: (1) Meningkatkan pengetahuan siswa dalam aspek kognitif dan psikomotor. (2) Mengembangkan bakat dan minat siswa dalam upaya pembinaan pribadi menuju pembinaan manusia Indonesia seutuhnya. (3) Mengetahui, mengenal serta membedakan hubungan antara suatu mata pelajaran dengan mata pelajaran lainnya.

Berdasarkan uraian diatas ditarik kesimpulan bahwa ekstrakurikuler sangat penting diberikan kepada siswa sebagai wadah kreatifitas peserta didik. Kegiatan ekstrakurikuler adalah suatu kegiatan yang dilakukan di luar jam pelajaran yang didalamnya terdapat proses pembelajaran dengan tujuan sebagai sarana untuk menyalurkan dan mengembangkan bakat dan minat siswa serta menumbuhkan nilai-nilai sikap ke arah yang positif.

\subsubsection{Musik Vokal}

\subsubsection{Pengertian Musik Vokal}

Menurut Sumaryanto (dalam jurnal Harmonia, 2005) musik adalah karya seni yang terbentuk dari gabungan unsur-unsur yang terdiri dari irama, melodi, harmoni, bentu atu struktur lagu dan ekspresif. Dari keenam unsur yang paling penting adalah irama/ ritme, melodi dan harmoni.

Musik adalah ungkapan perasaan yang dituangkan dalam bentuk bunyibunyian, Subagyo (2004:4). Lebih lanjut, menurut Simanungkalit (2008:1), musik adalah keindahan suara yang dapat didengar. Sumber suara ini dua macam asalnya, yang dihasilkan oleh alat-alat dan yang dihasilkan oleh manusia disebut 
musik vokal. Musik, baik vokal maupun instrumental, terdiri atas empat unsur : melodi, harmoni, irama (ritme), timbre (warna suara).

Musik vokal adalah karya musik yang dinyanyikan dengan suara manusia, Mack (dalam Utomo, 2014:10). Menurut Simanungkalit (2008:4), musik vokal adalah musik yang bersumber dari suara manusia, bisa dimainkan oleh seorang penyanyi atau sekelompok orang. Jika dinyanyikan perorangan disebut solo, dan jika dinyanyikan secara serempak disebut suara bersama (samen zingen). Suara bersama ini apabila dinyanyikan denagn harmoni dan berbagai warna suara (timbre) seperti sopran, mezzosopran, alto, contralto, tenor, bariton, bass, disebut musik paduan suara atau choir (koor).

\subsubsection{Paduan Suara}

\subsubsection{Pengertian Paduan Suara}

Paduan suara merupakan bentuk penyajian musik vokal yang dihadirkan oleh suatu grup, baik secara unisono maupun dalam beberapa suara. Wujud paduan suara (sehingga disebut paduan suara) adalah perpaduan antar suara menjadi satu warna suara, yaitu warna paduan suara dengan memperhatikan keseimbangan antar kelompok suara, satu ekspresi, dan merupakan satu kesatuan yang utuh, Suharto ( 2009 ). Vokal koor/ vokal paduan suara/ suara koor/ suara paduan suara dalam pelajaran ilmu paduan suara disebut choral voice sangat berbeda dengan suara solo. Suara paduan suara adalah bunyi serempak dari banyak anggota paduan suara. Untuk mencapai suara koor, syarat yang harus dilatih anatara lain warna vokal yang disuarakan harus sama dan jangan ada penonjolan warna suara perorangan, Simanungkalit (2008:44). 
Paduan suara adalah menyanyi bersama secara teratur dan terencana, pada waktu dan tempat tertentu dan secara rutin. Tujuannya adalah: bernyanyi bersama, mengungkapkan rasa baik senang maupun sedih dalam bernyanyi. Untuk mencapai tujuan tersebut perlu adanya: persatuan, tanggung jawab serta kerja sama, PML (2013:7). Lebih lanjut menurut Susetyo (2005:66), Paduan suara yang baik tidak harus terdiri dari vokalis yang hebat, tetapi cukup para penyanyi yang terdidik secara amatir tetapi mempunyai suara yang sepadan, artinya tidak ada yang menonjol secara berlebihan, sebab akan merusak keseluruhan. Para penyanyi yang mempunyai suara yang rata-rata berimbang dengan baik akan menghasilkan suara yang bulat dan suatu warna yang baru.

Berdasarkan uraian di atas dapat ditarik kesimpulan bahwa paduan suara adalah bentuk penyajian vokal secara bersama dalam suatu kelompok dengan memadukan berbagai jenis suara yang terdiri dari satu suara atau lebih menjadi satu kesatuan yang utuh, sehingga dalam paduan suara memiliki ikatan dan tujuan tertentu serta mempunyai tanggung jawab secara bersama-sama.

\subsubsection{Jenis dan Komposisi Paduan Suara}

Membentuk paduan suara berarti mempunyai suatu bayangan tentang paduan suara mana yang dicita-citakan, misalnya di sekolah dasar, tidak mungkin mendirikan paduan suara campuran. Menurut PML (2013:13), terdapat 4 jenis paduan suara yang umumnya dipakai di Indonesia berdasarkan jumlah yang ideal, ciri khas dan soal-soal khusus yang terdapat didalamnya. Jenis-jenis paduan suara terbagi menjadi sebagai berikut: 


\subsection{Paduan Suara Anak-Anak}

Jumlah anggota: sebaiknya antara 40-50 anak, bila jumlah terlalu kecil agak sukar bernyanyi dengan lembut sedangkan bila jumlah terlalu besar agak sulit menjaga ketertiban. Ciri khas: suara murni, polos dan tidak dibuat-buat serta mengandung suatu keindahan sehingga sudah cukup dengan suatu suara saja. Namun dapat pula dicoba bernyanyi dengan 2 atau 3 suara, lebih lagi kalau bisa diiringi. Persoalan khusus: (1) Terletak pada pembentukan suara. (2) ketepatan nada. (3) bahan nyanyian yang masih terbatas karena nyanyian tidak boleh terlalu simpel tetapi tidak terlalu sukar, PML (2013:13).

\subsection{Paduan Suara Remaja}

Jumlah anggota sebaiknya antara 15-50 orang anggota belum bisa disebut paduan suara dan apabila lebih dari 50 anggota kekompakan kurang terjaga. Ciri khas : terletak pada semangat para remaja dalam bernyanyi terutama dalam lagu yang mencerminkan semangat, misalnya untuk lagu-lagu perjuangan atau lagulagu daerah yang agak ritmis. Persoalan khusus: Untuk putra yang berumur 12 atau 13 tahun perlu diperhatikan bilamana mulai mutasi suara, pada fase ini suara tidak boleh dipaksa-paksa juga sesudah suaranya berubah, perlu dijaga agar nada yang ekstrim tinggi dan ekstrim rendah dihindari. Artinya suara dalam umur 1416 tahun masih terbatas wilayah suaranya dan baru berkembang sedikit demi sedikit menjadi makin mantap. Kemungkinan komposisi paduan suara untuk SMP: (1) SSA, tanpa suara putra yang suaranya telah berubah. (2) SST, dengan suara putra yang suaranya telah berubah. Kemungkinan komposisi paduan suara 
untuk SLA: (1) SATB, bila ada siswa putra dan putri. (2) SSA, atau untuk sekolah putri. (TTB, atau TTBB untuk sekolah putra, PML (2013:13-14).

\subsection{Paduan Suara Dewasa (Untuk Usia 18 Tahun Ke Atas)}

Jumlah anggota: setidak-tidaknya 20 anggota dan tidak ada batas maksimum. Sebagai bahan perbandingan adalah sebagai berikut: $\mathrm{S}=3=2 \mathrm{~T}=2 \mathrm{~B}$ 3. Ciri khas: paduan suara SATB bagi orang dewasa dianggap mempunyai bunyi yang paling bulat dan seimbang karena masing-masing suara sudah dapat berdiri sendiri terutama bila lagunya bergaya polifon. Paduan suara dewasa kalau dilatih dengan baik dapat berkembang mencapai mutu profesional dan kerah ekspresi musik yang disertai tarian dan sebagainya. Untuk tujuan yang bersifat insidental atau tetap maupun bersifat rekreasi atau ibadat, paduan suara dewasa dapat disesuaikan dengan mudah. Persoalan khusus: waktu latihan yang sempit terutama bila anggotanya banyak yang masih mahasiswa terjadi masa pasang surut sehubungan dengan musim ujian, pergantian anggota karena banyak anggota yang masih bujangan, dan tuntutan dirigen untuk bernyanyi yang baik dan menjiwai, PML (2013:14).

\subsection{Paduan Suara Sejenis}

Jumlah anggota: antara 25 - 30 orang. Ciri khas: paduan suara dengan 2 atau 3 suara, kalau dinyanyikan dengan halus akan tampak suatu keindahan meskipun tidak diiringi. Sebagai iringan dapat dipergunkan kolintang, angklung, piano, organ, atau gitar. 
Persoalan khusus: lagu yang disusun untuk paduan suara SSA masih terbatas, bila ada anggota yang melahirkan, hendaknya pakaian seragam jangan menjadi pokok, PML (2013:14).

\subsubsection{Teknik Vokal Dalam Bernyanyi}

Ada beberapa hal yang perlu diperhatikan dalam teknik bernyanyi, antara lains: teknik pernapasan, sikap badan, frasering, teknik resonansi, artikulasi, vibrasi, dan intonansi, Oktara (2011:41).

\subsection{Sikap Tubuh atau Sikap Badan}

Menurut Pranadjaja (dalam Sukrisno, 2015:3) sikap badan yang benar sangatlah penting sebab berpengaruh terhadap sirkulasi pernapasan yang merupakan unsur terpenting dalam bernyanyi dan langsung berakibat pada pembentukan suara. Menurut Linggono (2008:92), untuk dapat menyanyi dengan baik, diperlukan sikap tubuh yang rileks namun penuh tenaga. Tubuh yang rileks adalah sikap yang baik dan benar. Secara fisik, sikap bernyanyi adalah seluruh bagian tubuh harus selalu dalam keadaan tidak kaku. Menggerakan kaki, tangan, kepala dan badan seperlunya. Secara psikispun, dalam menyanyi perlu jiwa yang lentur atau tidak tegang. Pikiran harus positif dan jiwa perlu dilarutkan pada gerak musik. Sikap tubuh waktu bernyanyi merupakan hal yang penting. Untuk menjaga agar tidak menimbulkan ketegangan, maka berlatih untuk tidak selalu mengangkat bahu dan tidak menggerakan dada keatas harus dikuasi oleh seoarang penyanyi. 


\subsection{Pernapasan}

Menurut Jamalus (dalam Sukrisno, 2015:3), teknik pernafasan merupakan unsur terpenting dalam seni vokal (menyanyi) sebab suara terbentuk dari udara yang dihirup, tanpa nafas tidak akan bisa bersuara. Orang yang memiliki pernapasan yang buruk tidak mungkin bisa bersuara dengan baik. Sebaliknya orang yang bisa menguasai atau mengatur pernafasannya akan pula sanggup menguasai dan mengatur suaranya.

Menurut Linggono (2008:52-54), pernapasan untuk bernyanyi berbeda dengan pernapasan untuk aktivitas lain atau pada umumnya. Maka, untuk menentukan bentuk pernapasan yang tepat dalam bernyanyi perlu diketahui macam-macam jenis pernapasan. Ada tiga jenis pernapasan yang dapat digunakan dalam setiap aktivitasnya, yaitu antara lain: penapasan dada, pernapasan perut, dan pernapasan diafragma. Berbagai macam pernapasan tersebut memiliki cara dan keperuntukan tersendiri; pernapasan dada, pernapasan perut dan, pernapasan diafragma.

Keterangannya adalah sebagai berikut:

\section{1) Pernapasan Dada}

Cara pernapasan ini menggunakan daya tampung dada dalam pernapasan (mengembang dan mengempisnya paru-paru). Dengan demikian maka volume udara yang didapat hanya sedikit, sebatas daya tampung dan kemampuan mengembang rongga dada. Cara pernapasan ini tidak bisa digunakan untuk menyanyi karena sangat pendek dan tidak mampu memberi dukungan pencapaian pada nada tinggi, apalagi nada panjang. 


\section{2) Pernapasan Perut}

Pernapasan perut adalah cara bernapas dengan menggunakan perut sebagai daya tampung pernapasan, sehingga mengembang dan mengempisnya paru-paru selalu diikuti mengembang dan mengempisnya perut. Meskipun mampu menampung udara lebih banyak dibanding dengan pernapasan dada, cara pernapasan perut ini belum cukup baik untuk dimanfaatkan sebagai pendukung kegiatan bernyanyi. disebut belum cukup baik, karena teknik pernapasan perut ini selain tidak cukup panjang, juga sulit dikontrol dan dimanfaatkan sebagai pengantar nada yang stabil.

3) Pernapasan Diafragma

Pernapasan diafragma ini sebagai jenis pernapasan terbaik dari semua jenis pernapasan. Karena jenis pernapasan ini mampu menampung udara cukup banyak dan dapat dikendalikan dengan baik. Pernapasan diafragma menggunakan dua rongga tubuh sekaligus, yaitu rongga dada dan rongga perut, dan diatur oleh difragma.

Difragma adalah sekat diantara rongga dada dan rongga perut yang dalam sistem pernapasan ini adalah pengendali besar kecilnya udara yang dikeluarkan. Sehingga dengan demikian udara yang masuk cukup besar dan dikendalikan. Dalam bidang menyanyi, sangat mutlak diperlukan penguasaan terhadap teknik pernapasan ini, karena dalam menyanyi diperlukan napas-napas panjang untuk menggapai nada tinggi dan rangkaian nada yang panjang dalam lagu. Oleh sebab itu menjadi syarat utama bagi calon penyanyi untuk belajar dan menguasai teknik pernapasn diafragma ini. 
Menurut PML (2016:9-10), pernapasan diafragma yaitu paru-paru dapat terisi penuh tanpa terjepit, karena ruangan di perluas dengan menegangnya sekat rongga badan atau diafragma yang bergerak kebawah. Paru-paru sedikit mengembang. Pengeluaran napas disini terjadi karena diafragma menekan paruparu dari bawah serta dibantu oleh otot-otot perut dan otot-otot sisi badan. Dengan demikian pengeluaran napas diatur oleh kehendak kita sendiri dan menghasilkan suara yang meyakinkan. Pernapasan difragmalah yang paling baik untuk dilaksanakan waktu bernyanyi. tetapi tidak semua orang dapat melakukan dengan mudah. Banyak orang bernapas dengan kurang baik.

Lebih lanjut, menurut PML (2016:11), salah satu bentuk latihan pernapasan diafragma sebagai berikut: untuk memperkuat diafragma latihan dapat dilakukan dengan berbaring dan meletakkan buku yang agak berat diatas perut. Kemudian ambil napas. Usahakan supaya desakan napas tadi berhasil mendorong perut dengan beban tadi keatas. Dengan demikian otot perut dan diafragma menjadi lebih kuat. Bisa juga latihan ini dilakukan berdiri dengan kedua tangan menekan perut. Waktu mengambil napas, usahakan desakan dari difragma dapat mengatasi desakan tangan. Sesusah ditahan sebentar, napas dikeluarkan seperti biasa. Latihan yang paling sederhana untuk menguasai diafragma agar dapat bergerak dengan cepat dan kuat yaitu tertawa terbahak-bahak, sehingga perut merasa terguncang-guncang, sekaligus terusirlah kesedihan, ketakutan dan segala macam ketegangan. 


\subsection{Artikulasi}

Artikulasi adalah teknik pengucapan agar ucapan yang terdengar lebih jelas. Teknik ini juga berkaitan dengan teknik lain seperti diksi dan pembentukan suara. Teknik artikulasi memperhatikan pada ucapan-ucapan huruf hidup (vokal) dan huruf mati (konsonan), Destiannisa (dalam jurnal Harmonia, 2012:162-163).

Suatu bentuk lirik dalam nyanyian suatu karya musik terdapat suatu pesan yang akan disampaikan. Agar pesan dan kata-kata tersebut dapat dimengerti, maka saat bernyanyi harus memperhatikan artikulasi atau cara pelafalan kata demi kata dengan baik dan jelas sehingga memberikan pengertian yang jelas kepada pendengar, Oktara (2011:42).

\subsection{Resonansi}

Resonansi adalah fenomena yang ada sangkut pautnya dengan banyaknya rongga dalam tubuh manusia. Setiap orang yang menyanyi, resonansi akan timbul dari suara yang dihasilkan. Oleh sebab itu resonansi membantu memperbesar luas suara dan memperkuat daya tahan suara. Ruang resonansi utama terdapat di dalam kepala, dengan banyak bilik udara yang besar atau kecil, dan berpengaruh terhadap pembentukan suara. Getaran-getaran pita suara menjalar ke dalam bilikbilik yang meresonansi suara, Linggono (2008:105).

Resonansi adalah suatu gejala 'bunyi kembali' dari suatu ruangan, semacam gema yang timbul karena adanya ruangan yang memiliki dindingdinding yang keras sehingga sanggup memantulkan suara. Hal yang sama seperti ini dapat terjadi pada manusia. Tapa ruang resonansi pita suara hanya mampu menimpulkan bunyi yang lemah sekali, karena panjangnya hanya 1,5-2 cm. Baru 
dengan adanya ruangan udara yang beresonansi, suara manusia tidak hanya diperkeras tetapi terutama dapat diperindah dengan nada-nada yang gemilang, PML (2016:35).

\subsection{Intonasi}

Intonasi adalah teknik yang berhubungan dengan ketepatan nada (pitch). Ini sangat bersifat individu. Artinya, setiap anggota paduan suara harus memiliki kepekaan nada yang kuat sehingga mampu mengendalikan tinggi suaranya, dan tidak lagi terdengar nada-nada fals yang muncul saat penyajian. Satu orang terdengar fals maka rusaklah paduan suara itu. Jika banyak yang fals maka suara menjadi keruh. Penguasaan ini akan menjamin nada-nada fals pada grup itu. Sangat dianjurkan seluruh anggota paduan suara mampu membaca notasi musik. Latihan ini harus sering dilakukan, terutama saat vokalisi. Cara ini akan berguna baik yang sudah mampu membaca notasi maupun yang belum, Suharto (2009).

Alasan mengapa nada-nada dinyanyikan kurang tepat yaitu; (1) suasana bernyanyi terlalu tegang (2) kosentrasi dalam bernyanyi kurang (3) para penyanyi kehabisan napas (4) nada yang diulang atau ditahan melelahkan (5) para penyanyi kurang peka akan keselarasan dalam gabungan suara (6) kurang mahir membidik lompatan nada (7) nada-nada pada batas wilayah suara sukar dikuasai (8) nadanada pada batas suara sukar dinyanyikan (9) huruf-huruf dengan warna gelap dan terang mempengaruhi tinggi nada (10) kecenderungan mengikuti tangga nada lain (11) tergelincir waktu mengayunkan nada, PML (2016:41). 


\subsection{Frasering}

Frasering adalah teknik pemenggalan kalimat lagu. Teknik ini terkait juga dengan teknik pernafasan, dan interpretasi. Teknik ini penting karena salah mengiterpretasi, terutama dalam pemenggalan kalimat, akan mengurangi keindahan termasuk juga maknanya, Suharto (2009).

Menurut Linggono (2008:108), frasering adalah pemenggalan kalimat musik menjadi bagian-bagian yang lebih pendek, tetapi tetap mempunyai kesatuan arti. Tujuan frasering adalah agar dapat memenggal kalimat musik lebih tepat sesuai dengan isi kalimat. Dengan demikian usaha untuk mengungkapkan suatu lagu dapat lebih mendekati kebenaran yang terkandung didalamnya sesuai dengan pesan lagu tersebut.

\subsection{Vibrasi}

Vibrasi umumnya diterapkan di setiap akhir kalimat dari sebuah lagu. Seseorang penyanyi memang perlu memperindah suara dengan memberikan vibrasi pada lagu yang dibawakan. Vibrasi dapat diartikan sebagai upaya untuk memperindah lagu dengan jalan memberi gelombang atau suara yang mengalun teratur, Oktara (2011:43).

Vibrasi adalah suatu bentuk suara yang bergetar dan bergelombang. Dalam teknik olah vokal, vibrasi merupakan tahap finishing. Jika diibaratkan dengan memasak, vibrasi merupakan bumbu penyedap rasa yang membuat masakan terasa sempurna, lezat dan membangkitkan selera. Bila menyanyi diibaratkan memasak, maka vibrasi merupakan unsur penting dalam menyanyi, Linggono (2008:85). Lebih lanjut menurut Destiannisa (2012:162), vibrasi boleh digunakan 
asal jangan terlalu besar intensitasnya dan jangan menonjolkan individu. Sebaiknya hanya beberapa saja kecuali dia solois.

\subsection{Pembawaan dan Interpretasi}

Teknik ini cukup penting terutama berkaitan dengan bagaimana lagu itu dinyanyikan. Pesan lagu, karakter lagu, sampai pada bagian-bagian lagu (termasuk tanda-tanda ekspresi atau dinamik) harus bisa ditangkap oleh pelatih dengan baik. Tugas ini banyak dilakukan oleh pemimpin atau pelatih paduan suara. Penafsiran dan pengungkapan yang baik akan membawa penampilan paduan suara lebih baik pula. Pelatih harus bekerja keras untuk mencermati seluruh isi partitur lagu dan menerapkannya dalam paduan suaranya. Kegiatan ini bisa dilakukan secara bertahap mulai saat proses latihan sampai pada tahap penggosokan (finishing), Suharto (2009).

Seorang penyanyi harus dapat membawakan lagu dengan baik dari suatu ciptaan sesuai dengan jiwa lagu tersebut, misalnya sedih, gembira, semangat dan sebagainya. Sebuah lagu yang gembira harus pula disertai dengan mimik atau gerakan yang gembira pula. Bernyanyi dengan "perasaan" berarti bernyanyi dengan "hati". Sebelum menyanyikan lagu, alangkah baiknya jika sudah menghayati apa yang akan dinyanyikan. Karena selama bernyanyi harus menghayati isi nyanyian dengan perasaan atau hati, Linggono (2008:110).

\subsubsection{Bernyanyi dalam Paduan Suara}

Selain teknik sikap tubuh, pernafasan, membentuk suara, artikulasi, resonansi, intonasi, frasering, pembawaan dan interpretasi, ada beberapa faktor 
penting dalam bernyanyi paduan suara yaitu: keterpaduan (blend), keseimbangan (balance) dan sonoritas. Untuk lebih jelasnya akan diuraikan masing-masing faktor tersebut.

\subsection{Faktor Keterpaduan (Blend)}

Beberapa syarat untuk mencapai keterpaduan menurut Sitompul (1986:45) adalah: tinggi rendah nada (pitch), kualitas suara yang baik, pengguna register yang sama, pengguna vibrato yang terkendali, dan tingkat dinamik yang sama.

Menurut Suharto (2009), Padu bulat, menyatu (blend) itulah ciri utama musik paduan suara. Suara-suara dari banyak peserta dan kelompok suara yang berbeda harus menjelma menjadi satu warna dan satu bahasa yaitu warna paduan suara. Beberapa syarat untuk mencapai blend di dalam lingkungan satu kelompok suara: Tinggi nada (pitch) harus tepat-bersih. Nada yang tidak tepat antar suara menjadikan suara keruh. Di sinilah perlunya pemanasan (vokalizi) sebelum membawakan lagu. Kualitas suara yang baik ini tergantung dari cara membentuk suara dan cara membentuk vokal (vowels). Menggunakan register yang sama. Penggunaan register yang berbeda (ada yang falseto dan ada yang suara leher), juga antara sopran dan alto yang jauh warnanya menjadikan suara tidak padu (berwarna - warni).

\subsection{Faktor Keseimbangan}

Menurut Suharto (2009), Faktor keseimbangan tidak lepas dari blend. Jika dalam blend adalah untuk menciptakan kesamaan atau kepaduan antar personil dan kelompok suara maka teknik keseimbangan ini untuk menciptakan 
keseimbangan antar kelompok suara. Keseimbangan ini untuk menghindari tidak ada kelompok suara yang paling dominan suaranya. Keseimbangan ini bisa meliputi kekuatan, warna, dinamik, irama, dan sebagainya.

Dalam paduan suara harus ada keseimbangan antara suara sopran, alto, tenor dan bass. keseimbangan ini untuk menghindari adanya kelompok suara yang mendominasi suara dalam lagu yang sedang dinyanyikan, keseimbangan ini bisa meliputi kekuatan suara, irama dan sebagainya, Simanungkalit (2008:68).

\subsection{Sonoritas (kenyaringan dan kemerduan suara)}

Sonoritas yang dimaksud adalah kenyaringan dan kemerduan suara. Segera setelah peserta mulai bernyanyi, sudah ada kesan bagi pendengar bahwa suaranya merdu, nyaring, Simanungkalit (2008:68). Dari pendapat ahli tersebut dapat ditarik kesimpulan bahwa sonoritas dalam paduan suara merupakan perpaduan kualitas suara dengan membunyikan suara yang bening/ jernih dan merdu pada saat bernyanyi.

\subsubsection{Pemimpin Paduan Suara}

Didalam paduan suara ada pemimpin lagu atau yang disebut dengan kondakter/ Dirigen. Kondakting (INA) berasal dari kata conducting (ING) yang artinya memimpin, sedangkan orangnya disebut kondakter atau coducter (ING) yaitu seseorang yang betanggung jawab memimpin suatu pertunjukan musik disebut pemimpin. Oleh sebab itu dalam konteks musik kondakter adalah seseorang yang berdiri didepan kelompok musik yang memimpin dan mengarahkan pertunjukan musik pada waktu dan tempat tertentu, dengan sebaik- 
baiknya agar dapat dinikmat oleh masyarakat pendukungnya. Sedangkan prosesnya disebut kondakting, Susetyo (2005:1-2).

Syarat yang paling penting untuk kewibawaan dirigen adalah tidak berusaha mencari dan memperbaiki namanya sendiri tetapi mau mengabdi kepada paduan suara seluruhnya. Tidak menilai dirinya lebih tinggi daripada setiap anggota dari paduan suara sama seperti setiap penyanyi dari kelompok. Setiap anggota paduan suara menyadari bahwa ia dibutuhkan dan main peran, seperti dirigen jelas di butuhkan dan main peranan dalam paduan suara, PML (2013:13$61)$.

\subsection{Kerangka Berpikir}

Pendidikan seni atau yang disebut seni budaya merupakan mata pelajaran kesenian yang telah tercantum didalam kurikulum sekolah, yang termasuk didalamnya pendidikan musik. Pendidikan seni musik formal disekolah, selain sebagai mata pelajaran yang tercantum didalam kurikulum juga dapat diberikan melalui kegiatan ekstrakurikuler. Salah satu kegiatan esktrakurikuler dalam bidang seni yang ada di sekolah yaitu paduan suara.

Paduan suara adalah bentuk dari penyajian vokal secara bersama dalam suatu kelompok dengan memadukan berbagai jenis suara menjadi satu kesatuan yang utuh yang terdiri dari satu suara atau lebih. Sehingga dalam paduan suara memiliki ikatan dan tujuan tertentu serta mempunyai tanggung jawab secara bersama-sama.

Pembelajaran paduan suara merupakan kebutuhan yang sangat penting disekolah-sekolah karena sebagai media pengembangan keterampilan, minat dan 
bakat setiap siswa dalam bidang seni khususnya olah vocal yang didalamnya terdapat nilai-nilai pendidikan moral bagi siswa, oleh karena itu, SMP Negeri 2 Semarang mengadakan kegiatan ekstrakurikuler paduan suara di sekolah.

Dalam penelitian ini kerangka berpikir pembelajaran ekstrakurikuler paduan suara di SMP Negeri 2 Semarang sebagai berikut:

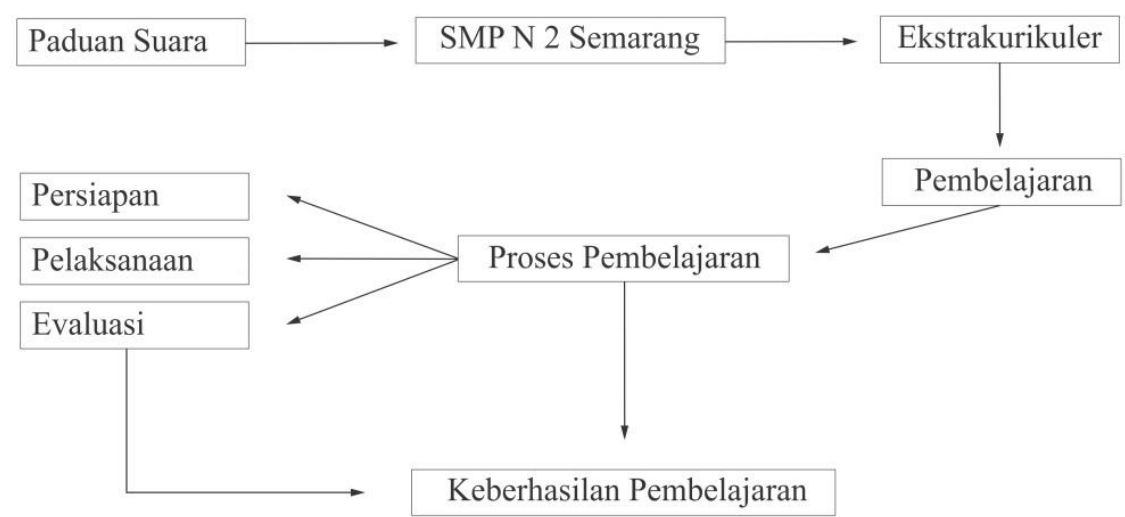

Gambar 1. Skema Kerangka Berpikir 


\section{BAB III \\ METODE PENELITIAN}

Dalam penelitian ini akan diuraikan mengenai pendekatan penelitian, lokasi penelitian, sasaran penelitian, teknik pengumpulan data, dan teknik analisa data. Metode yang digunakan dalam penelitian ini merupakan metode deskriptif kualitatif, artinya menyajikan data dengan menggunakan kalimat-kalimat berupa teks naratif kemudian dipisah-pisahkan. Deskritif karena penelitian ini bertujuan untuk menggambarkan atau menguraikan tentang pembelajarann ekstrakurikuler paduan suara dan faktor-faktor pendukung dan penghambat pembelajaran ekstrkurikuler paduan suara.

Penelitian kualitatif menurut Moleong (2007:6), adalah penelitian yang bermaksud untuk memahami fenomena tentang apa yang dialami oleh subjek penelitian misalnya perilaku, persepsi, motivasi, tindakan, dll, secara holistik, dan dengan cara deskripsi dalam bentuk kata-kata dan bahasa, pada suatu konteks khusus yang alamiah dan dengan memanfaatkan berbagai metode alamiah. Lebih lanjut menurut Sukmadinata (2009:94), penelitian kualitatif ditujukan untuk memahami fenomena - fenomena sosial dari sudut atau perspektif partisipan. Partisipan adalah orang-orang yang diajak berwawancara, diobservasi, diminta memberikan data, pendapat, pemikiran, persepsinya.

Penelitian kualitatif bertujuan memperoleh gambaran seutuhnya mengenai suatu hal menurut pandangan manusia yang diteliti. Penelitian kualitatif 
berhubungan dengan ide, persepsi, pendapat atau kepercayaan orang yang diteliti dan kesemuanya tidak dapat diukur dengan angka.

\subsection{Lokasi dan Sasaran Penelitian.}

\subsubsection{Lokasi Penelitian}

Penelitian ini mengambil lokasi di SMP Negeri 2 Semarang yang terletak di JL. Brigjen Katamso 14, Karanggtempel, Semarang Timur, Kota Semarang, Jawa Tengah. Penentuaan lokasi penelitian dilakukan karena sekolah ini merupakan salah satu sekolah terbaik di Kota Semarang. Sekolah ini mempunyai ektrakulikuler paduan suara yang banyak diminati oleh siswa dari sekolah tersebut. Selain itu SMP Negeri 2 Semarang merupakan SMP di Kota Semarang yang sudah lama melaksanakan kegiatan ektrakurikuler Paduan Suara dan mempunyai banyak prestasi untuk mempromosikan sekolah. Oleh karena itu, peneliti memilih SMP Negeri 2 Semarang sebagai objek yang diteliti.

\subsubsection{Sasaran Penelitian}

Sasaran kajian dalam penelitian ini adalah proses pembelajaran ekstrakurikuler paduan suara yang meliputi langkah-langkah yang harus dilakukan guru pada tahap persiapan pelaksanaan pembelajaran dan sesudah tahap pembelajaran, metode yang digunakan dalam pembelajaran paduan suara, materi pembelajaran yang disajikan, pengelolahan kelas, serta faktor pendukung dan penghambat yang ikut berpengaruh terhadap keberhasilan proses pembelajaran ekstrakurikuler paduan suara di SMP Negeri 2 Semarang. 


\subsection{Teknik Pengumpulan Data}

Teknik pengumpulan data adalah usaha untuk memperoleh bahan-bahan keterangan atau kenyataan yang benar dan dapat dipertanggung jawabkan. Pengumpulan data atau koleksi data merupakan tahapan dalam penelitian yang penting, karena hanya dengan mendapatkan data yang tepat maka proses penelitian akan berlangsung sampai peneliti mendapatkan jawaban dari perumusan masalah yang sudah ditetapkan, Sarwono (2006:123). Dengan demikian, maka tanpa mengetahui tehnik pengumpulan data, maka peneliti tidak akan memperoleh data yang memenuhi standar yang ditetapkan. Pada penelitian ini peneliti menggunakan teknik pengumpulan data dengan cara observasi, dokumentasi, dan wawancara.

Teknik pengumpulan data merupakan suatu proses pengadaan data primer dan data sekunder untuk memperoleh data yang akurat, sehingga hasil penelitian akan sesuai dengan tujuan yang ditetapkan. Dengan kata lain pegumpulan data bertujuan untuk memperoleh data yang sesuai dengan tujuan penelitian. Teknik yang telah dipilih untuk pengumpulan data di lapangan adalah sebagai berikut :

\subsubsection{Teknik Observasi}

Teknik observasi digunakan dalam penelitian ini dengan maksud untuk mendapatkan informasi dan data secara langsung dari lokasi penelitian. Teknik observasi adalah pengamatan yang dilakukan secara sengaja, sistematis mengenai fenomena sosial dengan gejala-gejala psikis untuk kemudian di lakukan pencatatan, Subagyo (2006:63). Menurut Sarwono (2006:224), kegiatan observasi meliputi melakukan pencatatan secara sistematik kejadian-kejadian, perilaku, 
obyek-obyek yang dilihat dan hal-hal lain yang diperlukan dalam mendukung penelitian yang sedang dilakukan.

Dalam penelitian ini, observasi dilakukan secara langsung. Dengan demikian peneliti adalah sebagai orang luar yang meneliti proses pembelajaran ekstrakurikuler paduan suara di SMPN 2 Semarang. Istilah lain adalah peneliti non partisipatif (nonparticipatory observatio), yaitu peneliti tidak terlibat secara langsung atau tidak ikut serta selama kegiatan, peneliti hanya mengamati kegiatan, Sukmadinata (2009:220).

Hal-hal yang diamati dalam penelitian ini adalah kegiatan pembelajaran dalam proses pembelajaran ekstrakurikuler paduan suara yang meliputi; proses kegiatan pembelajaran yang berlangsung, teknik dan metode yang digunakan pelatih dalam pembelajaran ekstrakurikuler paduan suara, interaksi pelatih dengan peserta paduan suara, materi yang diajarkan oleh pelatih, seperti materi lagu dan partitur, mengamati sikap dan minat siswa anggota paduan suara dalam mengikuti pembelajaran, mengamati proses penguasaan siswa dalam menerima pembelajaran.

\subsubsection{Teknik Wawancara}

Interview yang sering juga disebut dengan wawancara atau kuesioner lisan, adalah sebuah dialog yang dilakukan oleh pewawancara (interviewer) untuk memperoleh informasi dari terwawancara (interviewer), Arikunto (2010:198). Sementara itu, menurut Subagyo (2006:39), wawancara adalah suatu kegiatan dilakukan untuk mendapatkan informasi secara langsung dengan mengungkapkan pertanyaan-pertanyaan pada para responden. Wawancara bermakna berhadapaan 
langsung antara interviewer(s) dengan responden, dan kegiataannya dilakukan secara lisan.

Wawancara dalam penelitian ini dilaksanakan kepada responden yaitu pengajar atau pembina ekstrakurikuler, dan siswa di SMP Negeri 2 Semarang. Sebelum diadakan wawancara peneliti terlebih dahulu menyiapkan beberapa pertanyaan agar pelaksanaannya dapat terarah sesuai dengan tujuan yang ingin dicapai. Metode wawancara ini digunakan karena jika hanya menggunakan metode observasi saja belum cukup sehingga perlu adanya teknik lain untuk melengkapi. Melalui wawancara akan diperoleh data yang lebih spesifik dan akurat atau khusus sesuai dengan tujuan penelitian. Dalam melakukan wawancara peneliti menggunakan pedoman wawancara. Agar dapat mengungkapkan yang diinginkannya wawancara ini ditujukan langsung pada responden yaitu:

\subsubsection{Pelatih ekstrakurikuler paduan suara}

Yaitu mengenai proses pembelajaran yang meliputi jadwal pembelajaran, penentuan materi pembelajaran, teknik dan metode yang terapkan dalam pembelajaran, alam menghadapi siswa saat proses latihan dalam pembelajaran, dan faktor-faktor penghambat dan pendukung yang mempengaruhi proses kegiatan pembelajaran ekstrakurikuler paduan suara, tanggapan siswa dalam mengikuti pembelajaran.

\subsubsection{Siswa anggota ekstrakurikuler paduan suara}

Yaitu mengenai pendapat siswa tentang kegiatan ektrakurikuler paduan suara, apakah mereka rutin atau tidak dalam mengikuti ekstrakurikuler paduan 
suara, minat siswa dalam mengikuti ekstrakurikuler paduan suara, harapkan siswa setelah bergabuang dalam anggota ekstrakurikuler paduan suara, perasaan siswa jika terpilih menjadi tim paduan suara mewakili sekolah, pendapat siswa mengenai cara mengajar pelatih, serta hambatan yang dialami siswa anggota ekstrakurikuler paduan suara dalam mengikuti proses pembelajaran.

\subsubsection{Kepala Sekolah}

Yaitu megenai keadaan SMP Negeri 2 Semarang, baik secara fisik maupun infrastruktur, sejarah ekstrakurikuler paduan suara serta sejak kapan kegiatan ekstrakurikuler paduan suara diselenggarakan, tujuan diselenggrakan ektrakurikuler paduan suara, prestasi yang telah diraih oleh ektrakurikuler paduan suara, peran kepala sekolah terhadap ektrakurikuler paduan suara, penilaian kepala sekolah terhadap pelatih paduan suara. Hasil wawancara diharapkan dapat mengumpulkan data sebanyak-banyaknya mengenai kegiatan ekstrakurikuler paduan suara di SMP Negeri 2 Semarang selaras dengan masalah yang ingin diketahui. Teknik yang digunakan berupa wawancara terarah, yaitu dengan cara memberikan pertanyaan sesuai dengan pertanyaan yang sudah disiapkan.

\subsubsection{Teknik Dokumentasi}

Teknik dokumentasi adalah mencari data mengenai hal-hal atau veriabel yang berupa catatan, transkip, buku, surat kabar, majalah, prasasti, notulen rapat, lengger, agenda, dan sebagainya, Arikunto (2010:274). Teknik dokumentasi digunakan untuk mengumpulkan keterangan tentang peristiwa yang tercatat dalam gambar-gambar yang dapat menunjukan bukti dari suatu kegiatan. Terdapat dua 
kategori foto yang dapat dimanfaatkan dalam penelitian kualitatif, yaitu foto yang dihasilkan orang dan foto yang dihasilkan peneliti sendiri.

Bahan - bahan dokumen yang dijadikan sumber dokumentasi dalam penelitian ini adalah data mengenai informasi tentang kegiatan ekstrakurikuler paduan suara di SMPN 2 Semarang seperti data letak geografis, luas, dan data yang berhubungan dengan pembelajaran seperti data lagu, dokumentasi, penghargaan prestasi yang diraih, serta kegiatan pembelajaran atau kegiatan lain yang sudah ada. Hasil dokumentasi tersebut selanjutnya akan melengkapi atau mendukung data hasil dari observasi dan wawancara.

Teknik ini dilakukan untuk memperoleh data sekunder guna melengkapi data yang belum diperoleh melalui teknik observasi dan wawancara. Data primer adalah data yang diperoleh secara langsung dari responden melalui wawancara, sedangkan data sekunder adalah data yang digunakan untuk membantu menyelesaikan data primer berupa arsip-arsip dan dokumentasi dari instansiinstansi terkait.

Bahan dokumentasi yang dijadikan sumber data sebagai pendukung penelitian ini adalah data-data mengenai struktur sekolah; jumlah guru, siswa dan karyawan; arsip sekolah berupa piagam penghargaan lomba dan gambar-gambar dokumentasi saat mengikuti perlombaan paduan suara, serta profil SMP Negeri 2 Semarang. Disamping itu peneliti juga menggunakan alat bantu kamera untuk mengambil gambar-gambar yang berkaitan dengan pembelajaran ekstrakurikuler paduan suara di SMP Negeri 2 Semarang, yang meliputi; gambar gedung SMP Negeri 2 Semarang, gambar ruangan khusus ekstrakurikuler paduan suara, gambar 
sarana dan prasarana yang digunakan dalam pembelajaran ekstrakurikuler paduan suara, gambar piala-piala kejuaran lomba paduan suara SMP Negeri 2 Semarang, arsip atau file gambar siswa saat mengikuti pementasan, data siswa yang mengikuti ekstrakurikuler paduan suara, foto pada saat pembelajaran ekstrakurikuler paduan suara.

\subsubsection{Teknik Pemeriksaan Keabsahan Data}

Data penelitian yang telah diperoleh akan diuji keabsahannya dengan teknik triangulasi. Triangulasi adalah teknik pemeriksaan keabsahan data yang memanfaatkan sesuatu yang lain di luar data itu untuk keperluan pengecekan atau pembanding terhadap data itu, Moleong (2002:178).

Menurut Denzim (dalam Prastowo, 2016:269-270) Ada beberapa jenis triangulasi yaitu triangulasi sumber, teknik dan waktu. Triangulasi sumber adalah suatu teknik pengecekan kreadibilitas data yang dilakukan dengan memeriksa data yang didapat melalui beberapa sumber. Triangulasi teknik yaitu digunakan untuk menguji kreadibilitas data yang dilakukan dengan cara mengecek data kepada sumber yang sama dengan teknik yang berbeda. Sedangkan triangulasi waktu adalah teknik yang dilakukan dengan cara melakukan pengecekan dengan wawancara, observasi, atau teknik lain dalam waktu atau situasi yang berbeda.

Dalam hal ini, peneliti menggunakan triangulasi sumber, karena peneliti mengambil data dari beberapa sumber, yaitu dari kepala sekolah, guru pembina ekstrakurikuler paduan suara dan peserta anggota paduan suara. Peneliti juga menggunakan triangulasi teknik, karena peneliti mengambil data dengan menggunakan beberapa teknik, yaitu teknik observasi, wawancara dan 
dokumentasi. Triangulasi dilakukan dengan membandingkan hasil wawancara, dengan hasil observasi dan dokumentasi dengan tujuan mengecek kebenaran dan penafsiran data guna memperoleh kesimpulan, sehingga yang menjadi fokus penelitian ini dapat terjawab secara sistematis dan bertanggung jawab.

\subsection{Teknik Analisis Data}

Analisis data menurut Usman (2014:84), ialah kegiatan analisis mengategorikan data untuk mendapatkan pola hubungan, tema, menaksirkan apa yang bermakna, serta menyampaikan atau melaporkannya kepada orang lain yang berminat. Menurut Subagyo (2006:106) teknik analisis data adalah kegiatan untuk memanfaatkan data sehingga dapat di peroleh suatu kebenaran atau ketidak benaran dari suatu hipotesa.

Analisis data kualitatif adalah upaya yang dilakukan dengan jalan bekerja dengan data, mengorganisasikan data, memilah milahnya menjadi satuan yang dapat dikelola, mensintesiskannya, mencari dan menemukan pola, menemukan apa yang penting dan apa yang dipelajari, dan memutuskan apa yang dapat diceriterakan kepada orang lain, Bognan \& Biklen （dalam Moleong, 2007:248).

Berdasarkan definisi di atas dapat disimpulkan bahwa langkah awal dari analisis data adalah mengumpulkan data yang ada, menyusun secara sistematis, kemudian mempresentasikan hasil penelitiannya kepada orang lain. Dari hasil penelitian harus dianalisis secara tepat agar kesimpulan yang didapat akan tepat pula. Proses analisis data dilakukan secara sistematika dan serempak, mulai dari proses pengumpulan data serta kesimpulan dan interpretasi dari semua informasi yang secara selektif telah terkumpul. 
Dalam penelitian ini, data yang telah terkumpul dianalisis secara deskriptif. Data yang diperoleh selama tahapan pengumpulan data diseleksi, antara data yang sesuai atau tidak sesuai dengan materi penelitian. Kemudian data yang dianggap sesuai dianalisis dan disusun kedalam bentuk laporan penelitian.

Berikut adalah skema analisis data kualitatif yang dikemukakan oleh Miles dan Huberman (dalam Usman 2014:88).

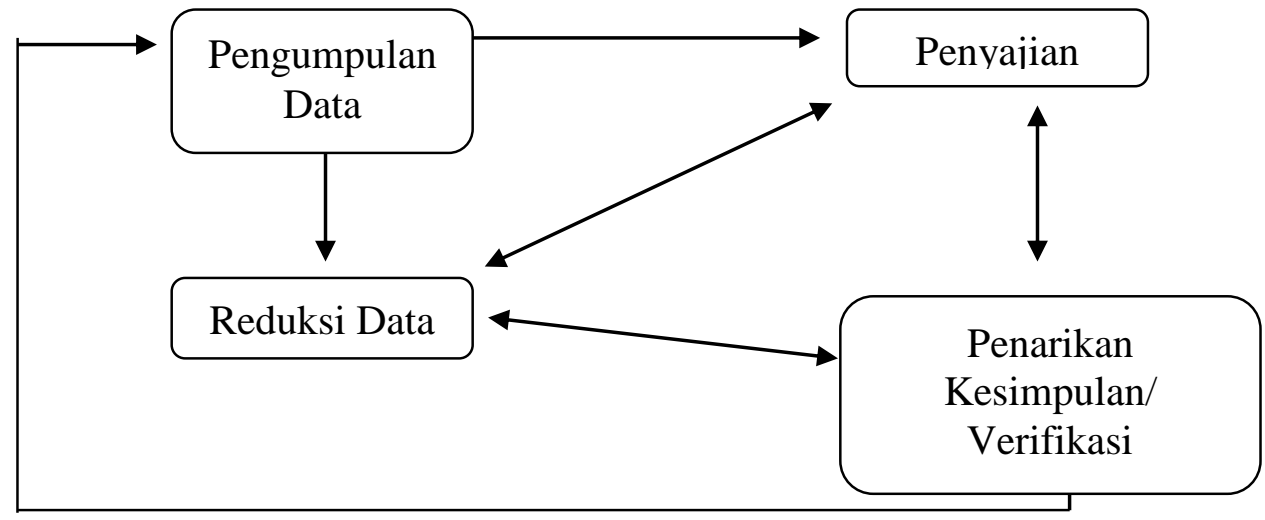

Gambar 2. Skema Analisis Data Kualitatif menurut Miles dan Huberman (dalam Usman 2014:88)

Teknik analisis data dalam penelitian ini menggunakan dilakukan menggunakan model penelitian kualitatif versi Miles dan Huberman. Analisis data terdiri dari tiga alur kegiatan yang secara bersamaan, yaitu reduksi, penyajian data, serta penarikan kesimpulan/ verifikasi.

Berikut penjelasan mengenai reduksi data, penyajian data, dan verifikasi menurut Miles dan Huberman (dalam Usman, 2014:85-88).

\subsubsection{Reduksi Data (Penyederhanaan)}

Reduksi data diartikan sebagai proses pemilihan, pemusatan perhatian pada penyerderhanaan, pengabstrakan, dan transformasi data "kasar' yang muncul 
dari catatan-catatan lapangan. Reduksi dilakukan sejak pengumpulan data, dimulai dengan membuat ringkasan, mengkode, menelusuri tema, membuat gugus-gugus, menulis memo, dan lain sebagainya, dengan maksud menyisihkan data/ informasi yang tidak relevan. Reduksi data merupakan suatu bentuk analisis yang menajamkam, menggolongkan, mengategorisasikan data sedemikian rupa sehingga akhirnya data yang terkumpul dapat diverifikasi.

\subsubsection{Penyajian Data}

Penyajian data adaalh pendeskripsian sekumpulan informasi tersusun yanmg memberi kemungkinan adanya penarikan kesimpulan dan pengambilan tindakan. Penyajian data kualitatif disajikan dalam bentuk teks natarif. Penyajian juga dapat berbentuk matriks, grafik, jaringan, dan bagan. Semuanya dirancang guna menggabungkan informasi yang tersusun dalam bentuk yang padu dan mudah dipahami.

\subsubsection{Proses Verifikasi/ Penarikan Kesimpulan}

Verifikasi data/ penarikan kesimpulan adalah kegiatan di akhir penelitian kualitatif. Peneliti harus sampai pada kesimpulan dan melakukan verifikasi, baik dari segi makna maupun kebenaran kesimpulan yang disepakati oleh subjek tempat penelitian itu dilaksanakan. Makna yang dirumuskan peneliti dari data harus diuji kebenaran, kecocokan, dan kekokohannya. Peneliti harus menyadari bahwa dalam mencari makna, ia harus menggunakan pendekatan emik, yaitu dari kacamata key informan, dan bukan penafsiran makna menurut pandangan peneliti (pendekatan etik). 
Penyajian data selain berasal dari hasil reduksi, perlu juga dilihat kembali dalam proses pengumpulan data untuk memastikan bahwa tidak ada data penting yang tertinggal. Demikian pula jika dalam verifikasi ternyata ada kesimpulan yang masih meragukan dan belum disepakati kebenaran maknanya, maka kembali ke proses pengumpulan data. Tindakan memvalidasi data sangat penting dalam penarikan kesimpulan. 


\section{BAB IV}

\section{HASIL PENELITIAN DAN PEMBAHASAAN}

\subsection{Gambaran Umum}

\subsubsection{Letak Geografis SMP Negeri 2 Semarang}

Data mengenai letak geografis SMP Negeri 2 Semarang ini diperoleh dari hasil dokumentasi Tata Usaha pada tanggal 11 Januari 2017. SMP Negeri 2 Semarang merupakan sekolah standar nasional di kota Semarang yang beralamat di jalan Brigjen Katamso 14 Semarang, kelurahan Karangtempel, kecamatan Semarang Timur, provinsi Jawa Tengah. SMP Negeri 2 Semarang terletak di perkotaan dan di pinggir jalan raya. Sebelah Timur berbatasan dengan perkampuangan karang ampel/ perumahan warga, sebelah selatan berbatasan dengan Jalan Brigjen Katamso dan showroom mobil "Duta cemerlang motor Suzuki”, sebelah barat berbatasan dengan Jalan Dr Cipto dan beberapa toko besar dan sebelah utara ada beberapa rumah penduduk dan pedagang kecil dan sebelah utara bernatasan dengan Jalan Halmahera.

SMP Negeri 2 Semarang letaknya sangat strategis karena tidak terlalu jauh dari pusat kota, terletak di sebelah jalan raya dan hanya berjarak $3,1 \mathrm{~km}$ dari simpang lima Semarang dengan mengambil rute ke arah Purwodadi. Transportasi untuk menuju SMP Negeri 2 Semarang juga mudah, karena banyak kendaraan transportasi umum yang melalui jalur yang menuju sekolah tersebut. Ketenangan kegiatan belajar mengajar cukup nyaman dengan didukung fasilitas belajar yang memadai. 


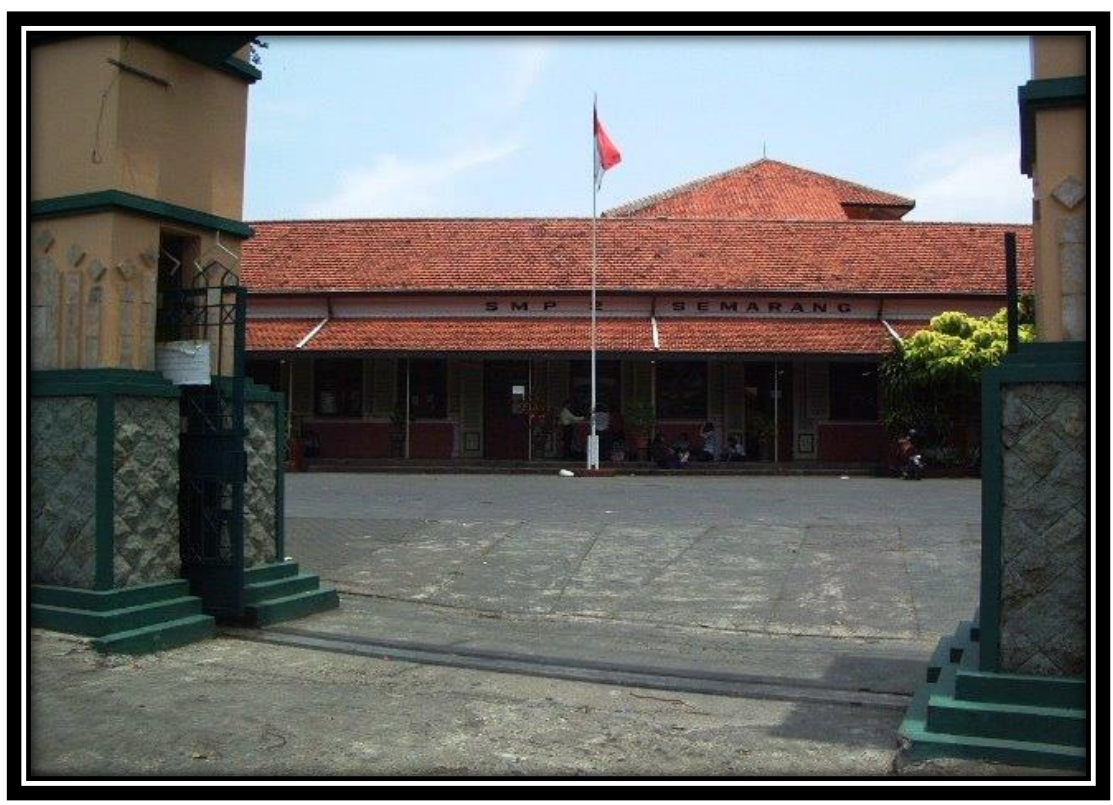

Gambar 3. SMP Negeri 2 Semarang (Foto: Ines, 2017)

\subsubsection{Terbentuknya Paduan Suara SMP Negeri 2 Semarang}

SMP Negeri 2 Semarang merupakan salah satu sekolah terbaik tingkat SMP di Semarang. Dalam proses pengembangan bakat siswa, SMP Negeri 2 Semarang memfasilitasi siswa dengan berbagai macam kegiatan ekstrakurikuler salah satunya ekstrakurikuler paduan suara. Data mengenai terbentuknya ekstrakurikuler paduan suara ini diperoleh melalui hasil dari wawancara dengan kepala SMP Negeri 2 Semarang bapak Teguh Waluyo S.Pd, MM pada tanggal 10 Januari 2017 dan dokumentasi ekstrakurikuler paduan suara.

Dalam rangka pengembangan kemampuan dan menggali potensi siswa untuk mengolah rasa dalam suara maka SMP Negeri 2 Semarang merasa perlu mengadakan kegiatan ekstrakurikuler salah satu cabang seni yaitu paduan suara. Paduan suara SMP Negeri 2 Semarang merupakan salah satu ekstrakulikuler yang 
baik untuk diikuti oleh siswa-siswi SMP Negeri 2 Semarang yang memiliki bakat dan minat dalam mengolah vokal yang dimiliki karena paduan suara merupakan wadah untuk melatih vokal dan pengolahan suara. Ektrakurikuler paduan suara juga melatih kekompakan antar sesama agar suara paduan suara menjadi sama dan sewarna. Tujuan adanya ekstrakurikuler paduan suara adalah untuk membentuk sikap dan mental siswa agar dapat diterapkan dalam kehidupan sehari-hari. Karena didalam ekstrakurikuler paduan suara selain siswa belajar berolah vokal didalam pembelajaran juga menanamkan nilai-nilai seperti belajar bekerjasama, saling menghargai, percaya diri, serta disiplin.

Paduan Suara SMP Negeri 2 Semarang di beri nama Espero Choir, berdiri pada tanggal 13 Mei 2002 di bawah naungan Kepala Sekolah Teguh Waluyo, S.Pd, MM atas prakarsa dan bimbingan guru seni musik Sudaryono, S.Pd. Tim Espero beranggotakan siswa-siswi kelas VII dan VIII. Perekrutan anggota dilakukan setiap tahun ajaran baru dan bebas bagi semua siswa SMP Negeri 2 Semarang tanpa dilakukan seleksi. Namun pada saat mengikuti perlombaan dilakukan seleksi pada siswa yang sudah terdaftar dalam anggota ekstrakurikuler paduan suara. 
Berikut gambar logo ektrakurikuler paduan suara SMP Negeri 2 Semarang.



Gambar 4. Logo ekstrakurikuler paduan suara (Foto: Dokumentasi, 2017)

Makna logo ekstrakurikuler paduan suara SMP Negeri 2 Semarang sebagai berikut :

- Garis lingkaran melengkung 3 membentuk dunia melambangkan perpaduan suara antara sopran, mezzo dan alto yang menjadi satu kesatuan yang utuh untuk menciptakan keharmonisan.

- Logo kunci G melambangkan lambang musik.

- Tulisan SMP 2 berwarna kuning melambangkan keemasan atau kejayaan.

- ESPERO CHOIR di atas merah putih melambangkan kecintaan pada Indonesia.

- $\quad$ Semarang adalah letak atau tempat asal dari SMP 2.

- Warna biru melambangkan tingkatan SMP. 


\subsubsection{Prestasi Ekstrakurikuler Paduan Suara SMP Negeri 2 Semarang.}

Data prestasi paduan suara SMP Negeri 2 Semarang ini diperoleh melalui hasil wawancara dengan kepala sekolah bapak Teguh Waluyo S.Pd, MM dan dokumentasi pada tanggal 10 Januari 2017. Prestasi yang diraih oleh sekolah merupakan suatu kebanggaan tersendiri bagi sekolah. Dengan adanya prestasi dapat meningkatkan mutu sekolah dan menjadikan sekolah dikenal oleh masyarakat luas. Dengan adanya prestasi sekolah dapat menunjukan kepada kalayak sebagai ajang promosi sekolah.

Paduan suara SMP Negeri 2 Semarang yang disebut Espero Choir terkenal dengan prestasinya dalam mengikuti lomba. Banyak prestasi yang diraih oleh paduan suara SMP Negeri 2 Semarang baik tingkat provinsi maupun tingkat nasional. Prestasi yang telah berhasil dicetak oleh paduan suara SMP Negeri 2 Semarang merupakan salah satu hal yang dapat mempengaruhi kelangsungan penyelenggaraan kegiatan ekstrakurikuler paduan suara.

Dengan banyaknya prestasi memberi dampak bagi siswa-siswi untuk tertarik mengikuti ekstrakurikuler paduan suara ini. Siswa sangat beminat pada ektrakurikuler paduan suara, hal ini dapat dilihat dari banyaknya jumlah siswa yang mengikuti ekstrakurikuler paduan suara di SMP Negeri 2 Semarang.

Berikut prestasi yang pernah diraih paduan suara SMP Negeri 2 Semarang:

(1) Juara paduan suara tingkat Jawa Tengah tahun 2006, diselenggarakan oleh USM. 
(2) Juara paduan suara tingkat Jawa Tengah tahun 2008, diselenggarakan oleh USM.

(3) Medali perak paduan suara tingkat Nasional tahun 2008, diselenggarakan oleh ITB.

(4) Medali perak paduan suara tingkat Nasional tahun 2010, diselenggarkan oleh ITB.

(5) Juara 2 lomba paduan suara Nasionalisme tingkat propinsi tahun 2014.

(6) Juara 2 paduan suara tingkat Jawa Tengah di SMA YSKI 2014

(7) Juara 2 paduan suara tingkat Jawa Tengah di SMA Taruna Nusantara 2014.

(8) Juara 1 lomba paduan suara ulang tahun Kota Semarang 2015.

(9) Juara 1 paduan Suara KNPI Jawa Tengah 2014.

(10) Medali perak Nasional Choir Competation UNDIP 2013.

(11) Medali perak Nasional Choir Competation UNDIP 2015.

(12) Medali emas Nasional Choir Festival USM 2016.

(13) Medali perak Satya Dharma Gita National Choir Festival tahun 2013.

(14) Juara 1 lomba paduan suara se-Kota Semarang tahun 2013.

(15) Juara 2 Nasional (FLS2N) Vokal Group di Surabaya tahun 2010.

(16) Juara 1 lomba paduan suara Universitas Semarang tingkat Nasional tahun 2010.

(17) Juara 2 lomba paduan suara se-Jawa Tengah dan DIY tahun 2013.

(18) Juara 1 kelompok paduan suara dan dirigen terbaik tingkat Jawa Tengah 2014 
(19) Lomba paduan suara juara medali emas tingkat nasional tahun 2016.

Selain prestasi dalam bidang lomba, paduan suara SMP Negeri 2 Semarang juga memiliki berbagai pengalaman pentas antara lain:

(1) Menyambut kedatangan Presiden RI pada pembukaan Semarang Pesona Asia tahun 2006.

(2) Program tahunan menjadi tim paduan suara upacara bendera pada peringatan Proklamasi Kemerdekaan RI di Simpang Lima.

(3) Menjadi tim paduan suara pada kegiatan pembukaaan Jambore Nasional Dirgantara tahun 2009 di Bumi Perkemahan Candradimuka Semarang.

(4) Menjadi tim paduan suara pembukaan FLS2N tingkat Nasional di Marina Convention Hall.

(5) Menjadi team paduan suara Hari Guru tingkat Provinsi 2014-2016

(6) Menjadi team paduan suara penyambutan Duta Besar Australia di gedung Berlian 2016

(7) Menjadi paduan suara pembukaan Popda di Trilomba Juang 2016

(8) Menjadi team paduan suara Hari Pendidikan Nasional Jawa Tengah 2016

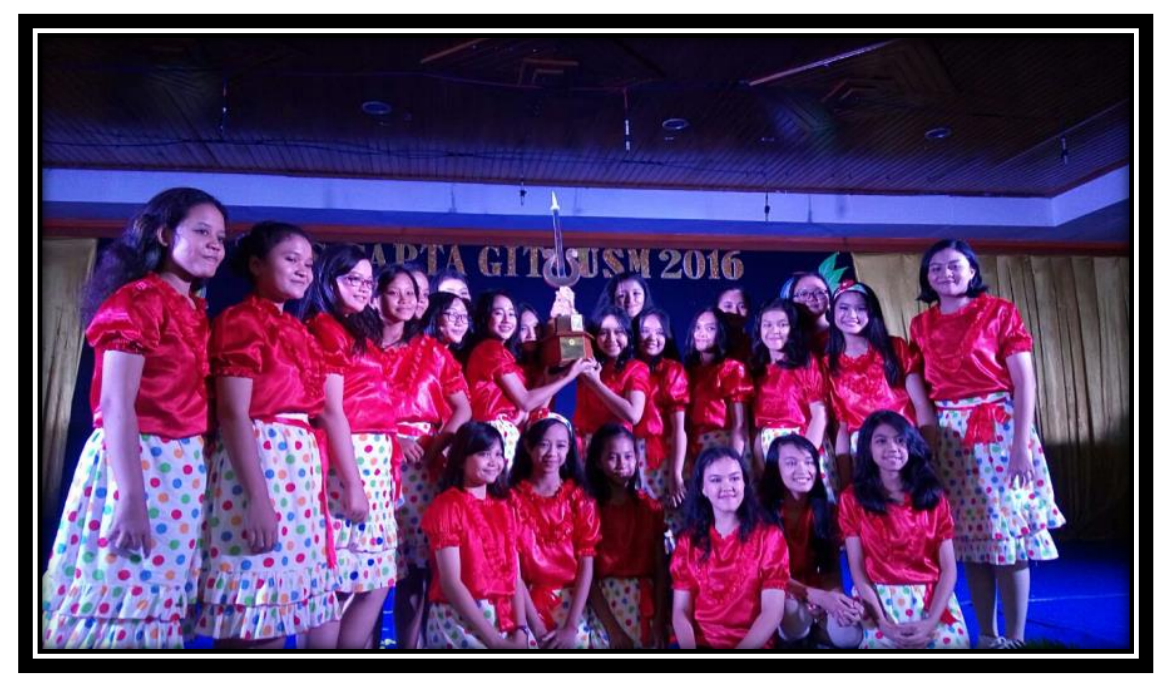


Gambar 5. Penerimaan piala bergilir sebagai juara umum

Nasional Choir Festival USM (Foto: Dokumentasi, 2017)

Banyak penghargaan yang diraih tentu karena adanya dukungan dari pihak

sekolah. Selain itu penghargaan yang di diraih juga karena adanya proses pembelajaran paduan suara itu sendiri yang di terapkan oleh pelatih kepada siswa anggota paduan suara di SMP Negeri 2 Semarang.

\subsection{Proses Pembelajaran Ekstrakurikuler Paduan Suara SMP Negeri 2 Semarang}

Data mengenai proses pembelajaran ekstrakurikuler paduan suara ini diperoleh dari melakukan observasi dilapangan pada tanggal 16 Januari 2017 dan wawancara dengan pelatih paduan suara bapak Sudaryono S. Pd pada tanggal 10 Januari 2017. Bapak Sudaryono S. Pd selaku pelatih ekstrakurikuler paduan suara di SMP Negeri 2 Semarang mengatakan ada tiga tahapan dalam proses pembelajaran, meliputi: tahap perencanaan, tahap pelaksanaan dan tahap evaluasi.

\subsubsection{Tahap Perencanaan}

Perencanaan adalah menyusun langkah-langkah yang akan dilaksanakan untuk mencapai tujuan yang telah ditentukan. Proses pembelajaran selain diawali dengan perencanaan yang bijak, serta didukung dengan komunikasi yang baik, juga harus didukung dengan pengembangan strategi yang mampu membelajarkan siswa, Saputri (2013:38-39). Di dalam pembelajaran ekstrakurikuler paduan suara tahap perencanaan meliputi langkah-langkah yang akan dilakukan oleh pelatih dalam mempersiapkan kegiatan belajar mengajar, rencana kegiatan tersebut 
diantaranya sebagai berikut: (1) Persiapan materi lagu (2) Mendata siswa (3) Menyiapkan alat bantu pembelajaran. Adapun langkah-langkah yang dilakukan dalam perencanaan sebagai berikut:

\subsubsection{Persiapan Materi Lagu.}

Secara umum sebelum melaksanakan kegiatan pembelajaran ekstrakurikuler paduan suara, pelatih menyiapkan materi pembelajaran lagu yang akan dipelajari bersama dalam pembelajaran ekstrakurikuler. Sebelumnya pelatih menyiapkan lagu yang akan diajarakan terlebih dahulu. Kemudian sebelum pembelajaran paduan suara dilaksanakan, lagu tersebut diberikan kepada siswa yang ditunjuk agar kemudian dapat dibagikan keseluruh anggota paduan suara. Berikut salah satu materi lagu yang disiapkan oleh pelatih untuk pembelajaran.

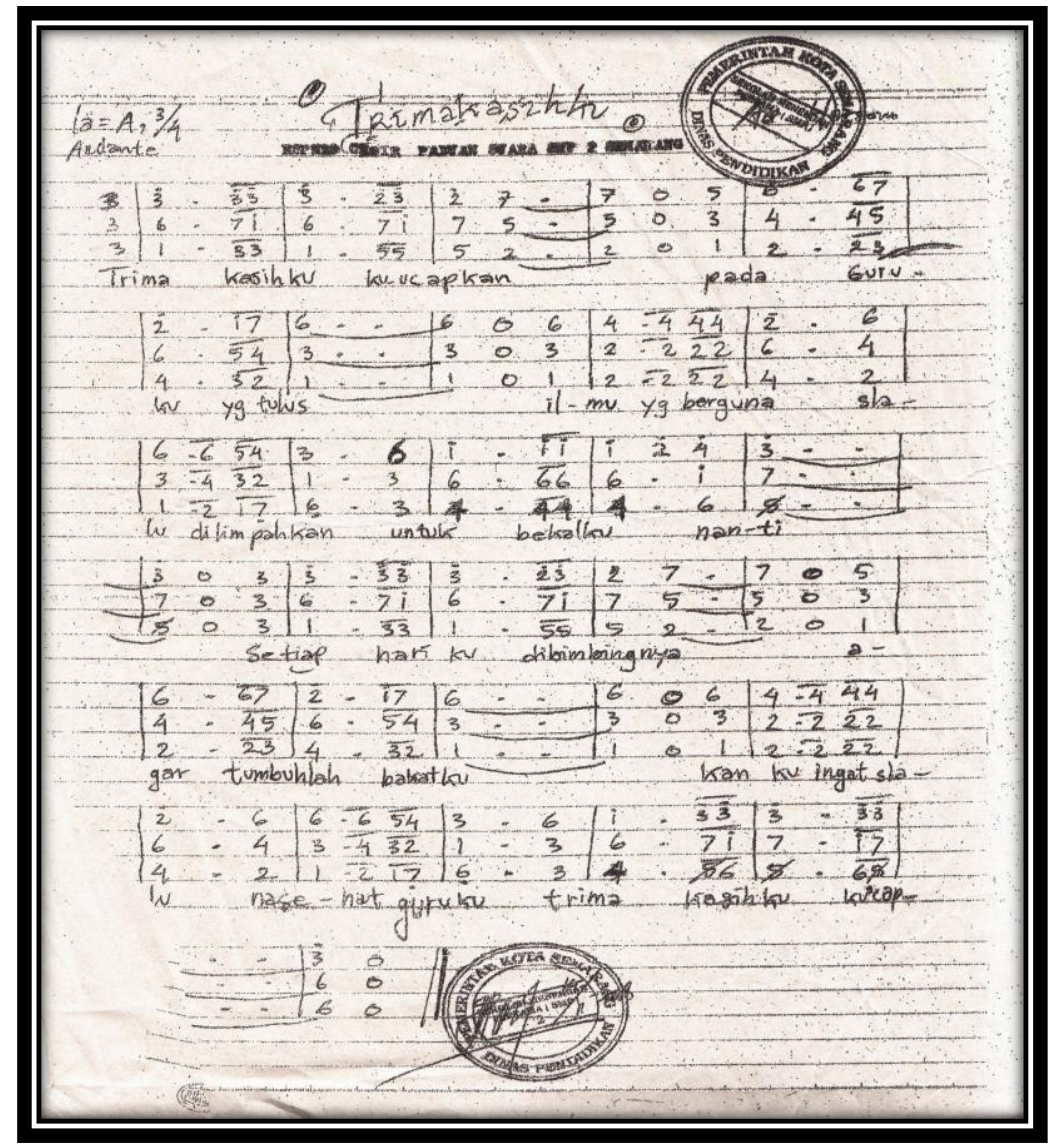




\subsubsection{Mendata Siswa}

Sebelum kegiatan pembelajaran ekstrakurikuler paduan suara dimulai, pelatih selalu mendata kehadiran siswa anggota paduan suara. Kegiatan ini dilakukan untuk mengetahui kedisiplinan siswa dalam hal kehadiran, dari presensi dapat di lihat siswa yang aktif dan tidak dalam mengikuti kegiatan ekstrakurikuler paduan suara. Dalam kegiatan pembelajaran ekstrakurikuler paduan suara kehadiran siswa merupakan aspek penting untuk mendukung berjalannya kegiatan pembelajaran.

Pelatih selalu memberi motivasi kepada siswa anggota paduan suara untuk selalu dapat hadir di setiap kegiatan ekstrakurikuler paduan suara. Hal tersebut supaya siswa tidak tertinggal dalam menerima pembelajaran serta mempercepat proses penyerapan materi yang diberikan kepada siswa anggota paduan suara.

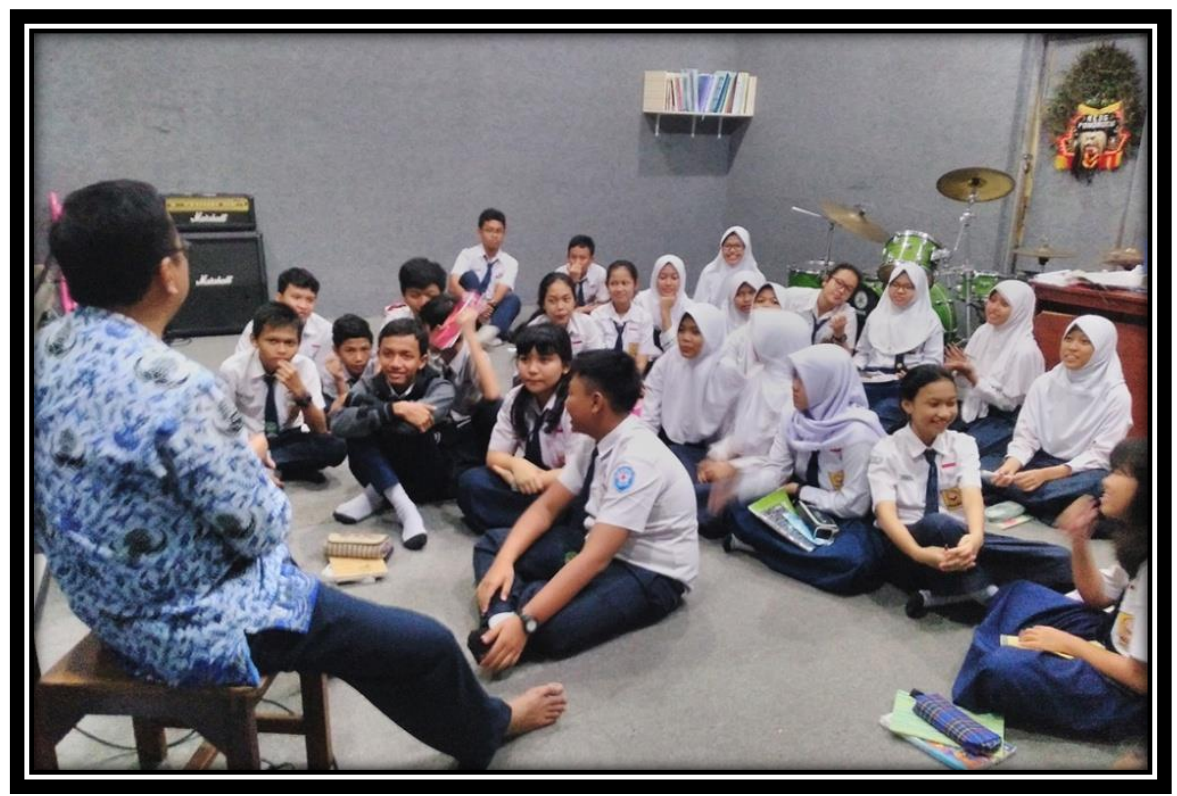


Gambar 6. Mendata siswa (Foto: Dokumentasi, 2017)

Selain itu kehadiran juga mempengaruh nilai akhir pada aspek kedisiplinan siswa yang akan dimuat di daftar nilai raport.

\subsubsection{Menyiapkan Alat Bantu Pembelajaran}

Secara umum setelah pelatih mendata siswa, biasanya pelatih memberikan instruksi kepada siswa anggota paduan suara untuk menyiapkan alat musik keyboard sebagai alat bantu pembelajaran ekstrakurikuler paduan suara. Alat bantu yang digunakan dalam pembelajaran paduan suara di SMP Negeri 2 Semarang adalah keyboard Yamaha PSR 2100.

Alat musik keyboard digunakan pada saat latihan menyanyi, saat melakukan pemanasan vokalisi dan membantu pelatih untuk membunyikan nadanada termasuk nada dasar apabila saat latihan anggota paduan suara mengalami kesulitan dalam ketepatan nada. Selain itu pelatih juga menyiapkan kabel instrument serta papan teks yang akan dipakai untuk pembelajaran.

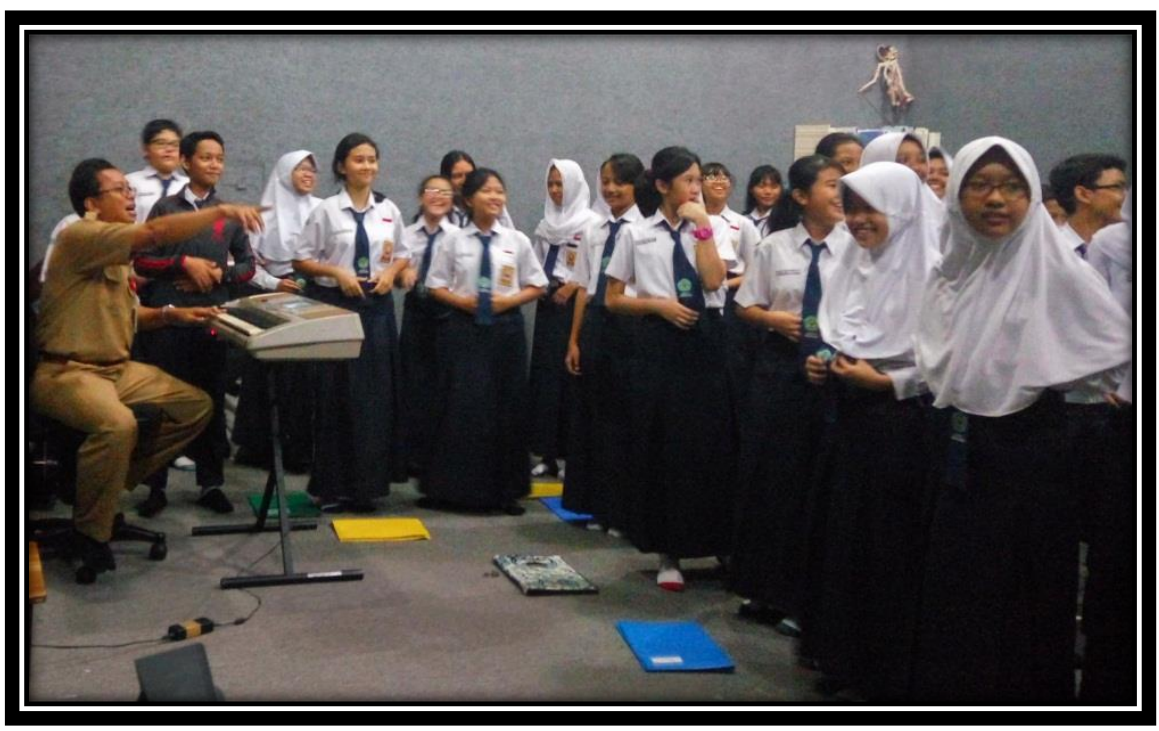


Gambar 7. Menyiapkan alat bantu pembelajaran (Foto: Ines, 2017)

Menurut peneliti, pada proses perencanaan pelatih telah melakukan langkah-langkah yang sudah sesuai dengan teori. Proses perencanaan dilakukan oleh pelatih untuk menyiapkan pembelajaran supaya dapat berjalan dengan lancar sesuai dengan tujuan dari pembelajaran itu sendiri. Proses perencanaan ini dilakukan sebelum masuk ke tahap pelaksanaan atau pembelajaran inti olah vokal dalam paduan suara.

\subsubsection{Tahap Pelaksanaan}

Data mengenai proses pembelajaran ekstrakurikuler paduan suara pada tahap pelaksanaan ini diperoleh dari melakukan observasi di lapangan pada tanggal 16 Januari 2017 dan wawancara dengan pelatih paduan suara bapak Sudaryono S. Pd pada tanggal 10 Januari 2017. Hasil wawancara yang diperoleh bahwa jadwal pembelajaran latihan rutin ekstrakurikuler paduan suara di SMP Negeri 2 Semarang dilaksanakan pada hari senin setelah jam pulang sekolah, yaitu jam 14.45 s/d 16.15. Waktu pelaksanaan dilakukan satu kali pertemuan dalam satu minggu.

Dalam proses kegiatan belajar mengajar ekstrakurikuler paduan suara di SMP Negeri 2 Semarang, kegiatan latihan dibagi menjadi dua yaitu kegiatan umum dan khusus. Kegiatan umum adalah kegiatan rutinitas peserta ekstrakurikuler paduan suara yang dilakukan setiap minggunya secara umum. Sedangkan kegiatan khusus adalah kegiatan yang dilakukan oleh peserta ekstrakurikuler paduan suara diluar jadwal umum yaitu kelas tambahan jika ada lomba atau pentas di acara- acara tertentu di luar guna lebih mengompakan satu 
kesatuan pembelajaran lagu. Tempat pelaksanaan ekstrakurikuler paduan suara dilakukan di ruang studio musik yang telah disediakan oleh sekolah dengan alatalat musik yang sudah memadai.

Pelaksanaan pembelajaran merupakan proses penyelenggaraan peserta didik dengan pendidik dan sumber belajar pada suatu lingkungan belajar, Majid (dalam Saputri 2013:39). Melalui pengamatan observasi yang dilakukan pada paduan suara SMP Negeri 2 Semarang diperoleh bentuk latihan sebagai berikut:

\subsubsection{Latihan Pemanasan}

Sebelum berlatih bernyanyi pelatih mengajak siswa anggota paduan suara untuk melakukan pemanasan terlebih dahulu. Pemanasan ini dilakukan bertujuan untuk mempersiapkan seluruh organ tubuh yang terlibat dalam proses bernyanyi, sehingga dapat diproduksi suara yang optimal. Pemanasan yang diajarkan pelatih dengan melakukan peregangan otot-otot tubuh, mulai dari kepala sampai kaki seperti memutar-mutar kepala, pundak, menggerak-gerakan pergelangan tangan, pinggang, dan kaki (lutut dan pergelangan kaki) secara ringan.

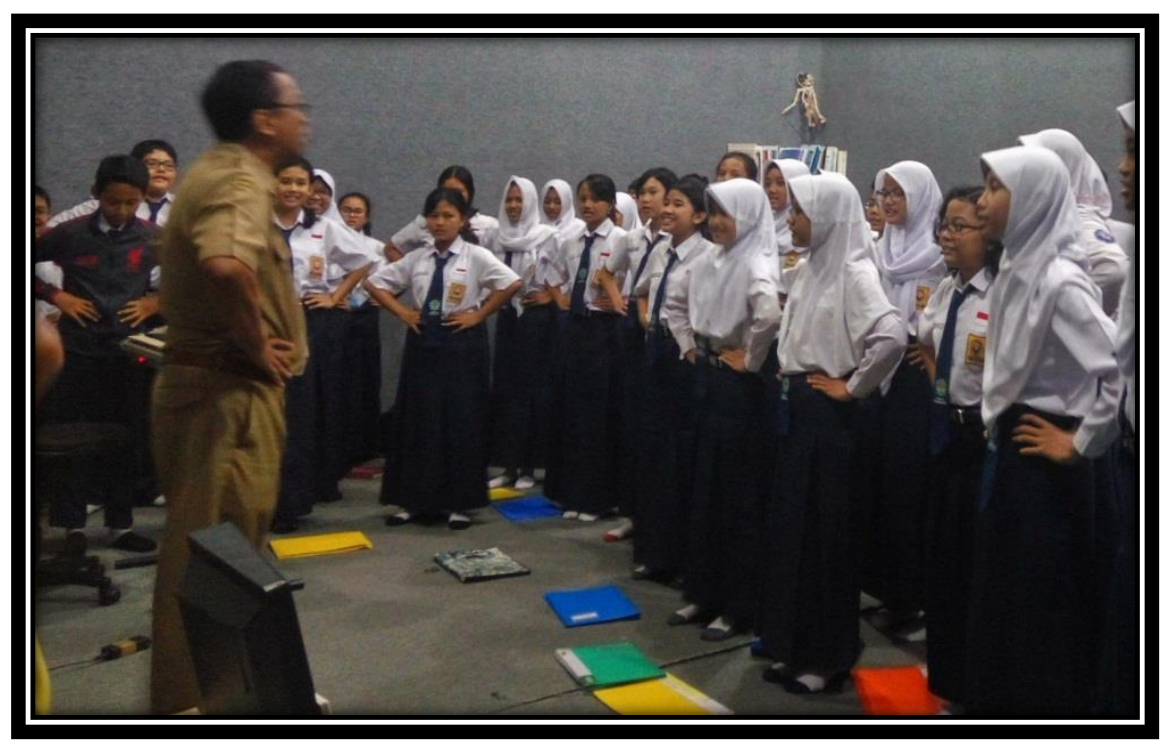


Gambar 8. Latihan pemanasan (Foto: Ines, 2017)

Latihan pemanasan ini bertujuan untuk membuat tubuh dalam keadaan rileks. Hal ini dianggap penting oleh pelatih supaya siswa tidak tegang saat bernyanyi oleh sebab itu pelatih selalu memberikan pemanasan di awal latihan paduan suara.

\subsubsection{Latihan Sikap Tubuh}

Data ini di peroleh dari pengamatan melalui observasi. Sebelum latihan dimulai pelatih mengkondisikan sikap tubuh yang benar kepada siswa anggota paduan suara. Semua anggota paduan suara berdiri untuk mengatur posisi tubuh saat bernyanyi. Pelatih memberi arahan dan mencontohkan sikap bernyanyi yang baik dan benar yaitu dengan badan lurus tegap tidak membungkuk, bahu tidak terangkat dan kepala tidak menunduk dan tidak juga tengadah ke atas, kaki kiri sedikit maju ke depan untuk menjaga keseimbangan, badan tidak kaku dan tegang melainkan tegap kuat tapi rileks.

Hal itu dilakukan supaya siswa melakukan sikap yang benar ketika bernyanyi karena hal itu dapat berpengaruh pada suara yang dihasilkan, selain itu agar siswa juga rileks dalam bernyanyi supaya latihan yang akan dilaksanakan mendapatkan hasil yang maksimal. Pelatih selalu mengingatkan kepada siswa anggota paduan suara mengenai sikap tubuh dalam bernyanyi. 


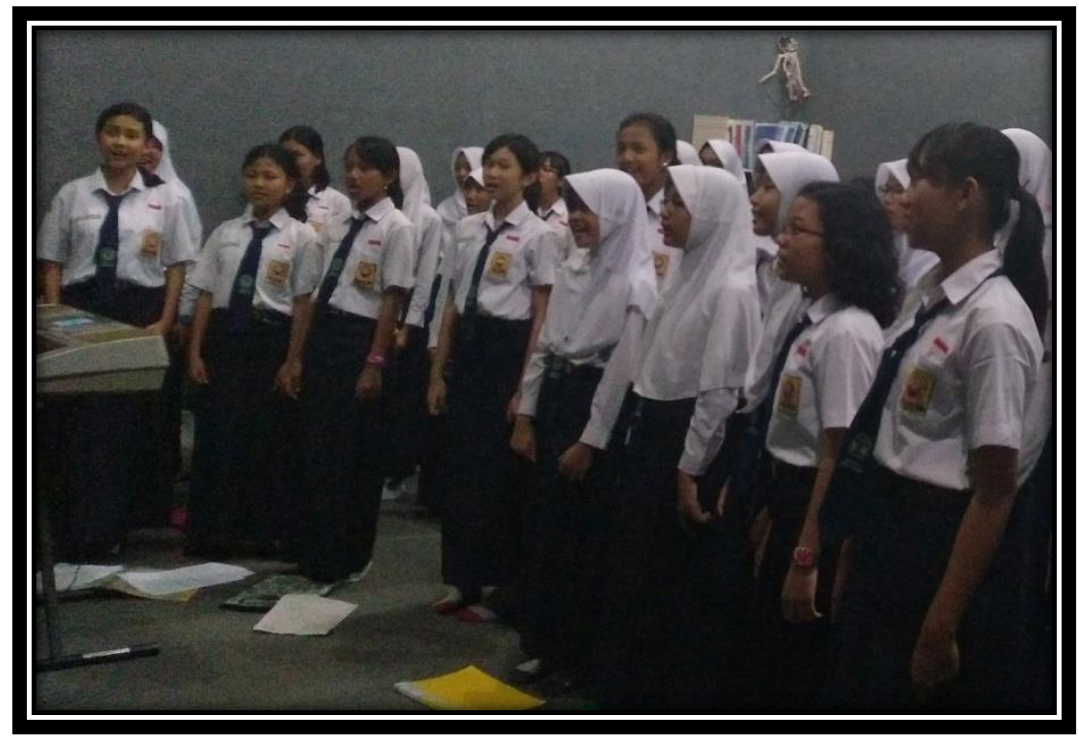

Gambar 9. Sikap tubuh dalam bernyanyi (Foto: Ines, 2017)

Dari pembahasan di atas mengenai latihan sikap tubuh, pelatih mengajarkan sikap tubuh kepada siswa serta memberikan contoh sikap tubuh yang baik dan benar dalam bernyanyi, kemudian siswa mempraktekannya langsung. Hal ini sependapat dengan teori yang diungkapkan menurut Linggono (2008:92), untuk dapat menyanyi dengan baik, diperlukan sikap tubuh yang rileks namun penuh tenaga. Tubuh yang rileks adalah sikap yang baik dan benar. Secara fisik, sikap bernyanyi adalah seluruh bagian tubuh harus selalu dalam keadaan tidak kaku. Menggerakan kaki, tangan, kepala dan badan seperlunya. Secara psikispun, dalam menyanyi perlu jiwa yang lentur atau tidak tegang, serta pikiran harus positif dan jiwa perlu dilarutkan pada gerak musik. Sikap tubuh waktu bernyanyi merupakan hal yang penting. Untuk menjaga agar tidak menimbulkan ketegangan, maka berlatih untuk tidak selalu mengangkat bahu dan tidak menggerakan dada keatas harus dikuasi oleh seoarang penyanyi. 
Kesimpulan yang didapat pada latihan sikap tubuh yang diajarkan oleh pelatih kepada siswa anggota paduan suara sudah sesuai dengan pendapat ahli. Pembelajaran sudah berjalan dengan baik karena siswa mau mendengarkan dan mempraktekan apa yang telah di contohkan mengenai sikap tubuh oleh pelatih sehingga siswa mengerti dan memahami fungsi dari latihan tersebut.

\subsubsection{Latihan Pernapasan}

Melalui observasi di lapangan saat pembelajaran berlangsung, pelatih menekankan kepada siswa anggota paduan suara bahwa pernapasan yang benar dalam bernyanyi yaitu dengan menggunakan pernapasan diafragma. Teknik diafragma dilakukan dengan cara menekan diafragma yang melintang antara rongga dada dengan rongga perut supaya posisi menjadi datar. Dalam keadaan demikian posisi rongga dada membesar dan kesempatan ini akan mengakibatkan udara leluasa menguasai paru-paru.

Dengan cara tersebut, peserta paduan suara akan merasa lebih nyaman untuk bernyanyi karena teknik ini tidak mengganggu bagian leher, bahu dan dada. Dalam teknik latihan pernapasan ini pelatih menerapkan metode demonstrasi, yaitu memberikan contoh cara pernapasan yang benar kepada siswa anggota paduan suara. Setelah itu siswa mempraktekannya sesuai dengan contoh yang diberikan. 


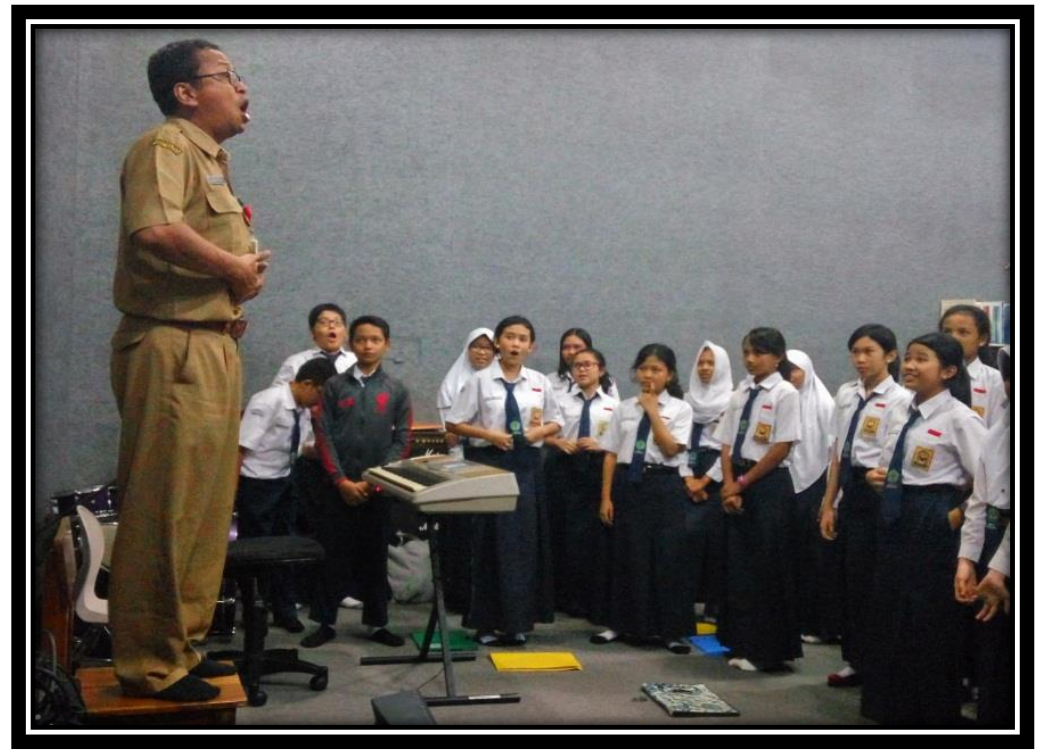

Gambar 10. Latihan pernapasan (Foto: Ines, 2017).

Berikut cara pelatih mengajarkan kepada siswa mengenai teknik pernapasan diafragma :

(1) Pelatih mengarahkan siswa untuk berdiri pada posisi tegak serta kedua tangan untuk memegang perut. Kemudian siswa anggota paduan suara menghirup udara sedalam-dalamnya melalui hidung dengan cara mengalirkan ke bagian rongga dada dan perut sehingga memperluas/ melebarkan sekitar perut dan pinggang (diafragma), juga penuhi udara ke bagian paru-paru lalu kunci untuk beberapa detik. Kemudian mengeluarkan udara melalui mulut dengan cara mendesis yaitu dengan bunyi Sssssssssss dengan nada panjang.

(2) Latihan pernapasan selanjutnya menggunakan cara pernapasan yang unik agar memudahkan siswa supaya mengerti dan paham, cara ini dinamakan pernafasan anjing. Pernapasan ini dengan cara bernafas seperti anjing yang 
terengah-engah yang diganti dengan mendesis dan dilakukan secara putusputus. Siswa mengeluarkan nafas dari mulut dengan mendesis yang dilakukan secara putus-putus sebanyak 4 kali kemudian diakhiri dengan mendesis panjang dengan dorongan dari otot perut dan diafragma. Hal ini dilakukan untuk merasakan udara yang keluar masuk diafragma dan bagian yg kembang kempis itu adalah diafragma. Hal ini dilakukan secara berulang-ulang.

Dari pembahasan mengenai latihan pernapasan bahwa teknik pernapasan yang diajarkan oleh pelatih yaitu teknik diafragma. Cara-cara yang diajarkan pelatih terhadap siswa anggota paduan suara mengenai teknik pernapasan diafragma dimaksudkan agar siswa paham akan penapasan yang baik dan benar saat bernyanyi sehingga siswa dapat menerapkannya ketika bernyanyi khususnya dalam paduan suara. hal tersebut sudah sependapat menurut Rudy (2008:52-53) bahwa, macam-macam pernapasan terdiri atas : (1) Pernapasan Dada, (2) Pernapasan Perut, dan (3) Pernapasan Diafragma. Rudy menegaskan bahwa, pernapasan diafragmalah sebagai jenis pernapasan terbaik dari semua jenis pernapasan. Karena jenis pernapasan ini mampu menampung udara cukup banyak dan dapat dikendalikan dengan baik.

Hal ini juga didukung dengan pendapat menurut PML (2016: 9-10) pernapasan diafragma yaitu paru-paru dapat terisi penuh tanpa terjepit, karena ruangan di perluas dengan menegangnya sekat rongga badan atau diafragma yang bergerak kebawah. Paru-paru sedikit mengembang. Pengeluaran napas disini terjadi karena diafragma menekan paru-paru dari bawah serta dibantu oleh otototot perut dan otot-otot sisi badan. Dengan demikian pengeluaran napas diatur 
oleh kehendak kita sendiri dan menghasilkan suara yang meyakinkan. Pernapasan difragmalah yang paling baik untuk dilaksanakan waktu bernyanyi.

Dengan demikian teknik pernapasan yang diajarkan pelatih sudah sesuai dengan teori yang dikemukakan oleh para ahli, akan tetapi pelatih mengajarkan menurut versi pelatih sendiri termasuk langkah-langkah yang diajarkan serta metode yang diterapkan dalam melatih pernapasan.

\subsubsection{Latihan Artikulasi}

Melalui data yang diperoleh dari observasi, pelatih mengajarkan kepada siswa anggota paduan suara mengenai artikulasi dengan cara mengarahkan siswa untuk melakukan senam mulut yaitu dengan mengucapkan artikulasi huruf hidup (vokal) A I U E O secara lantang dengan nada pendek dan ukuran mulut kira-kira selebar 3 jari dan dilakukan pengulangan secukupnya. Sedangkan huruf mati (konsonan) diucapkan seperti pengucapan biasa. Khusus untuk huruf $\mathrm{S}$ dab $\mathrm{R}$ diucapkan dengan penekanan dan harus jelas.

Dalam latihan pembentukan suara atau yang disebut artikulasi pelatih paduan suara menggunakan alat bantu keyboard untuk memandu siswa anggota paduan suara untuk melakukan vokalisai pelafalan huruf hidup A I U E O dengan tangga dasar di mulai dari yang rendah sampai mencapai nada dasar tinggi. Hal tersebut dilakukan untuk melatih siswa mau membuka mulut ketika bernyanyi agar suara yang dihasilkan jelas, sehingga makna dalam lagu tersampaikan.

Latihan vokalisasi dilakukan secara berulang-ulang, tujuannya untuk melatih artikulasi siswa. Artikulasi diajarkan oleh pelatih karena artikulasi salah satu teknik penting dalam bernyanyi termasuk dalam bernyanyi secara paduan 
suara. Artikulasi harus diajarkan kepada siswa agar kata- kata dapat diucapkan dengan jelas ketika bernyanyi, sehingga lagu yang dibawakan makna dan arti dari liriknya bisa tersampaikan oleh pendengar.

Berikut tangganada yang di gunakan pelatih SMP Negeri 2 Semarang.

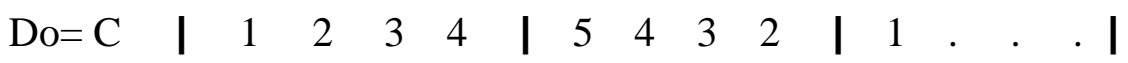
A I
U E
O A I E
$\mathrm{O}$

$\mathrm{Do}=\mathrm{D}$ dan seterusnya.

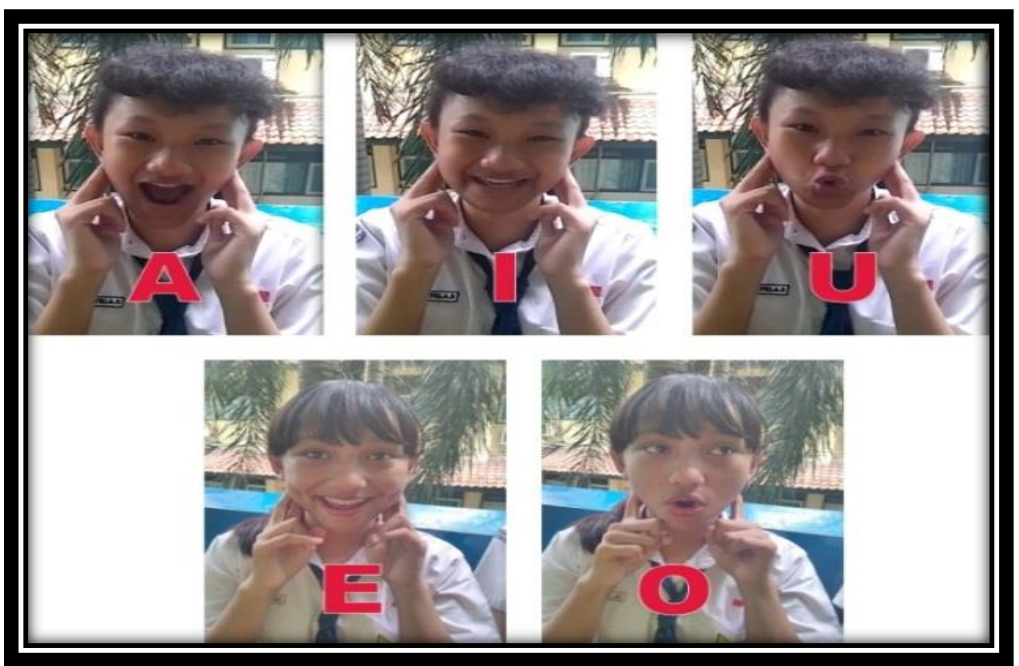

Gambar 11. Peragaan Artikulasi Huruf Vokal (Foto: Ines, 2017).

Melalui pembahasaan diatas, dalam mengajarkan artikulasi, pelatih menerapkan metode demostrasi yaitu pelatih memberikan contoh kemudian siswa menirukan atau mempraktekannya secara berulang-ulang. Pelatih mengajarkan artikulasi kepada siswa anggota paduan suara dengan cara pelafalan bunyi vokal A I U E O dengan tangga nada dari interval rendah ke interval tinggi dan juga huruf konsonan harus jelas dalam pengucapan dan penekanannya. Hal ini juga didukung dari landasan teori pada bab 2 bahwa artikulasi menurut Destiannisa (2012:162-163) adalah teknik pengucapan agar ucapan yang terdengar lebih jelas. 
Teknik ini juga berkaitan dengan teknik lain seperti diksi dan pembentukan suara. Teknik artikulasi memperhatikan pada ucapan-ucapan huruf hidup (vokal) dan huruf mati (konsonan). Oktara (2011:42), juga menegaskan suatu bentuk lirik dalam nyanyian suatu karya musik terdapat suatu pesan yang akan disampaikan. Agar pesan dan kata-kata tersebut dapat dimengerti, maka saat bernyanyi harus memperhatikan artikulasi atau cara pelafalan kata demi kata dengan baik dan jelas sehingga memberikan pengertian yang jelas kepada pendengar.

Dapat disimpulkan bahwa materi yang diajarkan oleh pelatih mengenai pelafalan huruf vokal menggunakan tangganada serta huruf konsonan dengan pelafalan dan penekanan yang jelas dapat membantu siswa dalam belajar melatih artikulasi. Hal ini dapat dilihat dari paduan suara SMP Negeri 2 Semarang memiliki artikulasi yang jelas saat bernyanyi.

\subsubsection{Latihan Intonasi}

Data ini diperoleh melalui pengamatan observasi, diketahui bahwa untuk memperoleh intonasi yang baik dalam bernyanyi, pelatih mengajarkan kepada anggota paduan suara untuk berlatih membaca notasi sehingga mereka tidak buta terhadap nada. Pelatih tidak menerapkan sistem yang hanya hafalan lagu saja, melainkan mengenalkan notasi angka pada lagu terlebih dahulu kemudian dilanjutkan dengan mempelajari lagu dalam bentuk syair. Banyak siswa yang dulunya tidak tahu sama sekali atau bahkan buta terhadap notasi namun lama kelamaan menjadi terbiasa dan paham sehingga bisa membaca notasi angka.

Siswa yang sudah terdaftar menjadi anggota paduan suara di tuntut untuk bisa membaca notasi angka. Pelatih menggunakan alat musik keyboard sebagai 
alat bantu dalam melatih ketepatan nada atau intonasi dengan memandu siswa untuk membaca notasi dan menyanyikannya secara bersama-sama dan berulangulang. Metode yang diterapkan pelatih yaitu metode drill dan latihan yaitu dengan cara melatih siswa, sehingga siswa menerapkan latihan tersebut secara berulangulang agar siswa dapat mengerti dan memahami apa yang diajarkan.

Berikut notasi yang digunakan:

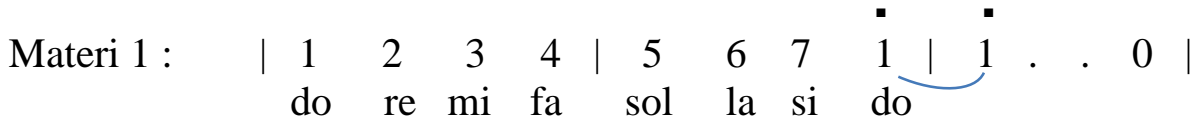

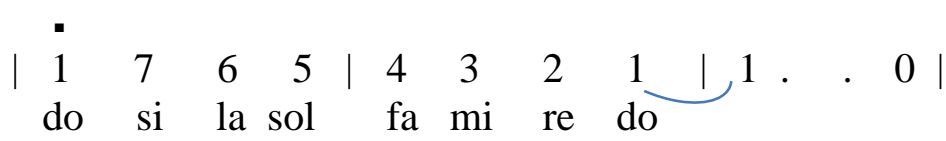

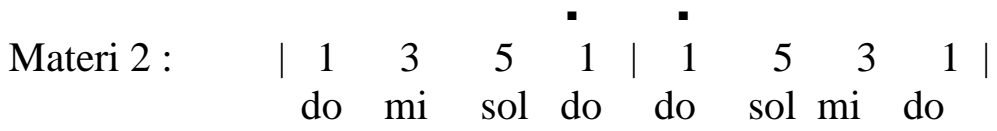

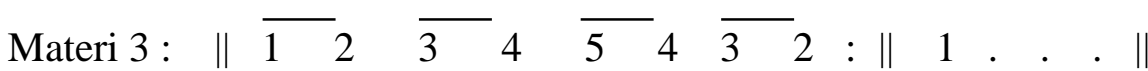
do re mi fa sol fa mi re do ma ma ma ma ma ma ma ma ma

$\begin{array}{lllllllllllllll}\text { Materi 4 : } & \overline{1} & 3 & 5 & \overline{1} & 5 & 3 & \overline{1} & 3 & 5 & 1 & 5 & 3 & 1 . & .\end{array}$ do mi sol do sol mi do mi sol do sol mi do ha ha ha ha ha ha ha ha ha ha ha ha ha

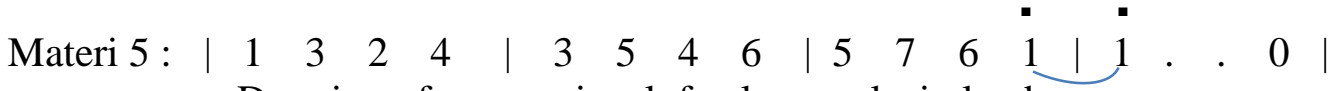
Do mi re fa mi sol fa la sol si la do

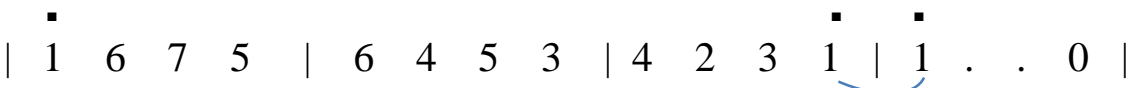
Do la la si la fa sol $\mathrm{mi}$ fa re mi do 


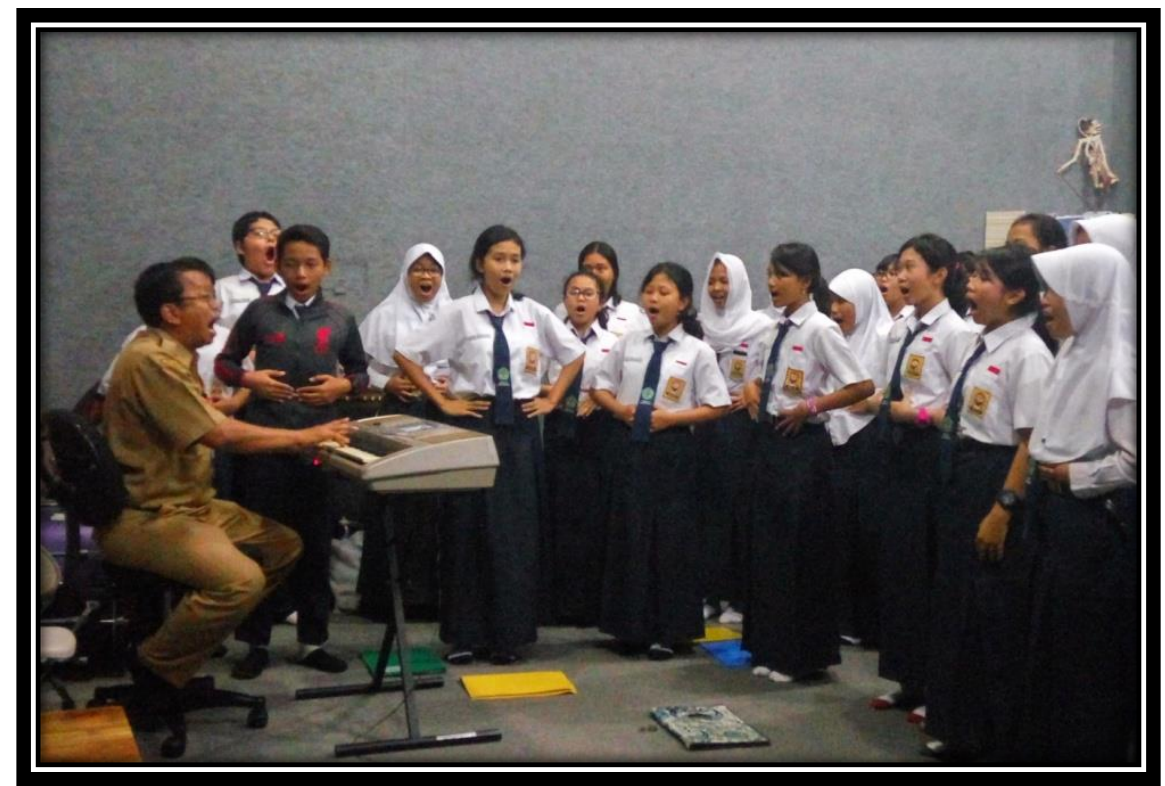

Gambar 12. latihan vokalisasi notasi untuk melatih intonasi (Foto: Ines, 2017)

Dari pembahasan mengenai latihan intonasi, pelatih mengajarkan vokalisasi dengan materi yang telah disiapkan oleh pelatih berupa notasi angka dengan metode drill yaitu dilakukan latihan secara berulang ulang. Dengan latihan ini bertujuan supaya siswa peka terhadap nada sehingga dapat mengontrol ketepatan nada/ pich dalam bernyanyi paduan suara.

Hal ini didukung dengan landasan teori pada bab 2 pada landasan teori menurut Suharto, (2009) Intonasi adalah teknik yang berhubungan dengan ketepatan nada (pitch). Ini sangat bersifat individu. Artinya, setiap anggota paduan suara harus memiliki kepekaan nada yang kuat sehingga mampu mengendalikan tinggi suaranya, dan tidak lagi terdengar nada-nada fals yang muncul saat penyajian. Satu orang terdengar fals maka rusaklah paduan suara itu. Jika banyak yang fals maka suara menjadi keruh. Penguasaan ini akan menjamin nada-nada fals pada grup itu. Sangat dianjurkan seluruh anggota paduan suara mampu membaca notasi musik. Latihan ini harus sering dilakukan, terutama saat 
vokalisi. Cara ini akan berguna baik yang sudah mampu membaca notasi maupun yang belum.

Dapat disimpulkan bahwa cara mengajar pelatih mengenai intonasi dapat di cerna oleh siswa. Cara yang di terapkan pelatih dengan materi notasi angka dengan dilakukannya vokalisasi secara berulang-ulang terbukti dapat meningkatkan kualitas vokal siswa anggota paduan suara SMP Negeri 2 Semarang dalam ketepatan nada/ intonasi. Karena dengan latihan intonasi berupa materi notasi angka yang di latih secara berulang-ulang, siswa menjadi terbiasa mendengar dan merasakan nada. Hal itu membuat siswa secara tidak langsung peka terhadap bunyi nada dan intonasi siswa pun dalam bernyanyi menjadi baik, terkontrol dan tidak sumbang.

\subsubsection{Latihan Membaca Notasi dan Syair Lagu}

Pada langkah selajutnya adalah pelatih mengadakan latihan membaca notasi dan syair lagu. Sebelum menyanyikan syair lagu, langkah pertama yang diterapkan oleh pelatih yaitu latihan membaca notasi lagu terlebih dahulu pada lagu yang akan diajarkan atau dinyanyikan. Semua anggota paduan suara diberi teks lagu, kamudian semua anggota dilatih untuk membaca notasi lagu secara bersama-sama dengan ketukan yang lambat, notasi dibaca tiap-tiap bagian lagu.

Jika pada saat latihan, lagu yang diajarkan unisono, setelah semua anggota paduan suara membaca notasi maka pelatih lanjut untuk ke materi mempelajari syair lagu. Namun jika lagu diajarkan mempunyai bagian-bagian suara seperti sopran, mezzosopran dan alto, pelatih mengajarkan sesuai dengan bagian suara masing-masing yang telah ditentukan. Pertama pelatih melatih kelompok sopran 
terlebih dahulu, setelah kelompok sopran dilatih membaca notasi, kemudian lanjut kelompok mezzosopran dan lanjut pada kelompok alto.

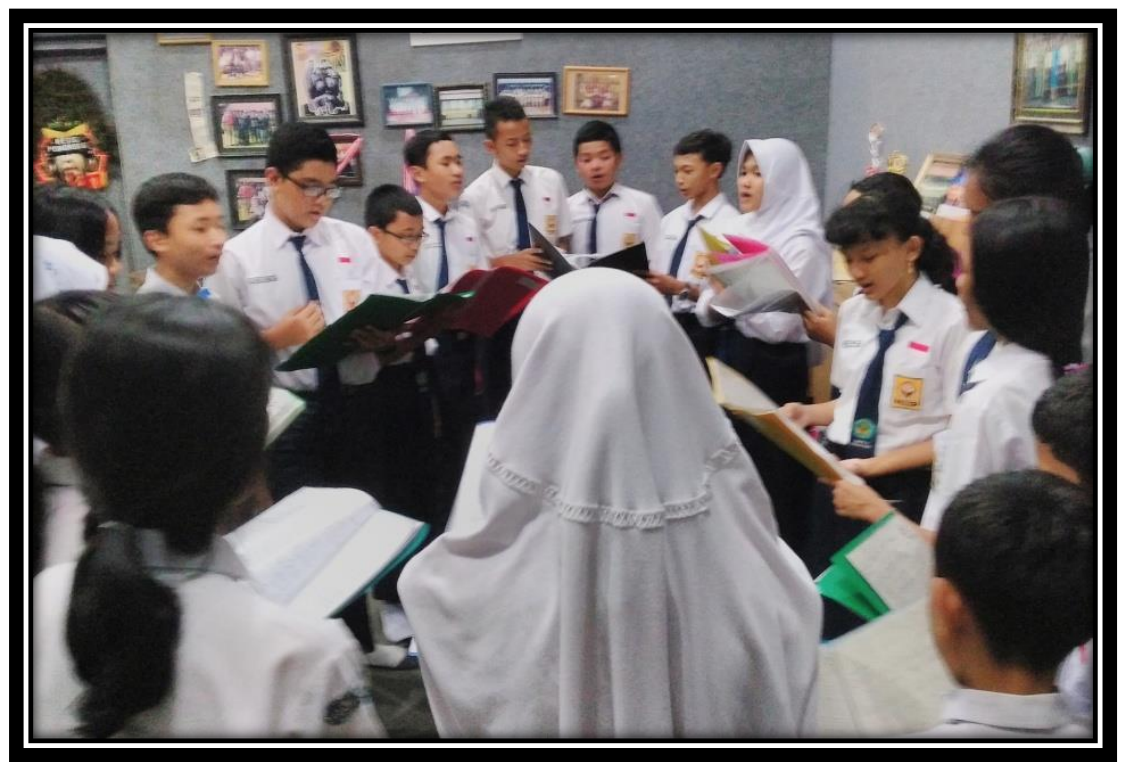

Gambar 13. Latihan membaca notasi sesuai dengan kelompok suara masingmasing (Foto: Ines, 2017).

Pada saat salah satu kelompok sedang dilatih membaca notasi, sembari menunggu giliran kelompok lainnya di beri kesempatan untuk belajar sendiri terlebih dahulu bersama kelompoknya secara mandiri tanpa pelatih. Metode tersebut disebut dengan metode tutor sebaya. Bagi siswa yang menonjol dalam berolah vokal dan membaca notasi dituntut untuk mengajarkan kepada temantemannya sesuai bagian suara yang telah di tentukan. Setelah membaca notasi lancar, tahap selanjutnya kemudian pelatih lanjut untuk mengajarkan syair lagu kepada anggota paduan suara. 


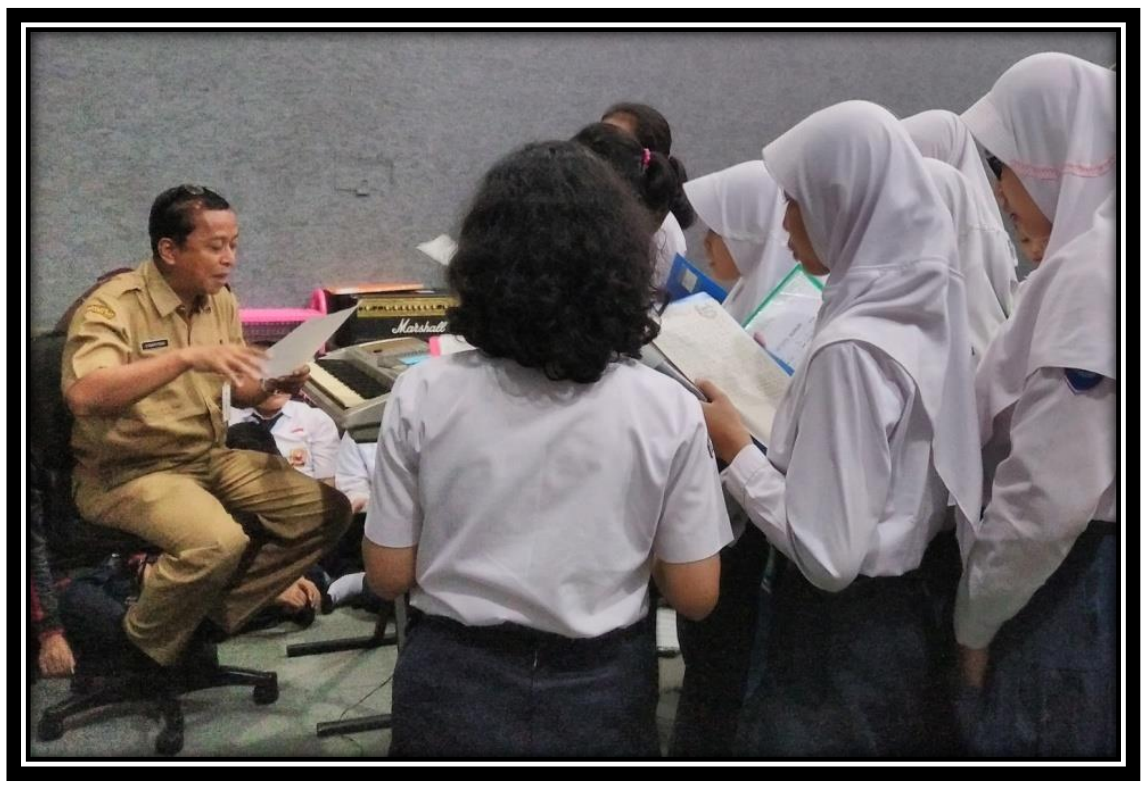

Gambar 14. latihan membaca notasi dan syair lagu (Foto: Ines, 2017).

Pada latihan syair lagu pelatih mengarahkan siswa untuk belajar per kelompok suara masing-masing dengan tujuan agar siswa mau mencoba menyesuaikan antara notasi lagu dengan syair lagu. Kemudian setelah siswa diberi kesempatan untuk belajar mandiri, siswa mempraktekan didepan pelatih mengenai apa yang sudah mereka pelajari. Setelah itu pelatih mengoreksi serta mengajarkan kepada siswa bagaimana cara membaca syair lagu dengan benar. Kemudian siswa mempraktekan apa yang diajarkan pelatih bersama-sama secara berulang-ulang. Hal tersebut merupakan metode latihan/ drill yang diterapkan pelatih dalam notasi lagu dan syair sampai siswa lancar dalam membaca syair lagu.

Dari pembahasan mengenai latihan membaca notasi dan syair lagu, pelatih menerapkan kepada siswa bahwa harus membaca notasi lagu yang berupa notasi angka terlebih dahulu sebelum masuk ke syair lagu. Disini disimpulkan bahwa 
pelatih tidak menerapkan sistem hafalan lagu saja, melainkan harus paham dan lancar membaca notasi lagu terlebih dahulu.

\subsubsection{Latihan Frasering}

Dari hasil observasi di peroleh data bahwa, pelatih mengajarkan kepada siswa anggota paduan suara pemenggalan kalimat yang tepat dalam lagu yang sedang dipelajari dengan cara pelatih memberikan contoh. Dalam latihan frasering perhatian tidak lagi pada kata-kata melainkan pada kalimat. Pelatih menjelaskan bahwa bernyanyi berarti membawakan suatu lagu dengan menghayati isi dari kata-kata sebagai ide atau pesan dan dengan menyadari nada-nada itu sebagai kesatuan.

Contoh lagu yang diajarkan :

Hallo / hallo Bandung / ibukota Periangan /

Hallo / hallo Bandung / kota kenang-kenangan /

Sudah lama beta / tidak berjumpa dengan kau /

sekarang sudah menjadi lautan api /

mari bung / rebut kembali. /

Dalam pemenggalan kalimat atau phrasering ini, bukan irama melodi yang menentukan, melainkan arti kata. Jadi, tatabahasa yang menjadi titik pangkal. Kemudian barulah phrasering melodi dan aksen-aksen irama disesuaikan. Contoh lagu lainnya yaitu lagu Ibu Kita kartini dan Tanah Airku sebagai berikut : 


\section{IBU KITA KARTINI}

$\mathrm{D}=\mathrm{do}, 4 / 4$ Andante

Wr. Supratman

\begin{tabular}{llll|lll|llll|l}
$1 \overline{2}$ & 3 & 4 & 5 & $\overline{3}$ & 1 & 1 & 6 & $\overline{.}$ & 7 & 6 & 5
\end{tabular}

bu ki ta kar ti ni, pu tri se ja ti

bu ki ta kar ti ni, pen de kar bangsa

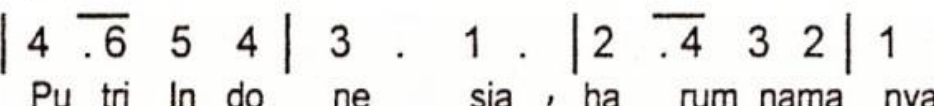
Pende kar ka um nya, un tuk merde ka

\begin{tabular}{llll|llll|llll|l}
4 & $\overline{3}$ & 4 & 6 & $\overline{56}$ & $\overline{53}$ & 1 & 3 & 2 & 3 & 4 & 5 & 3
\end{tabular} Wa hai i bu kita karti ni, pu tri yang mulia Wa

\begin{tabular}{llll|llll|llll|l}
4 & $\overline{3}$ & 4 & 6 & $\overline{56}$ & $\overline{53}$ & 1 & 3 & 2 & 4 & 7 & 2 & 1
\end{tabular}$.. .1$ Sungguh besar cita-cita nya,ba gi In do ne sia 


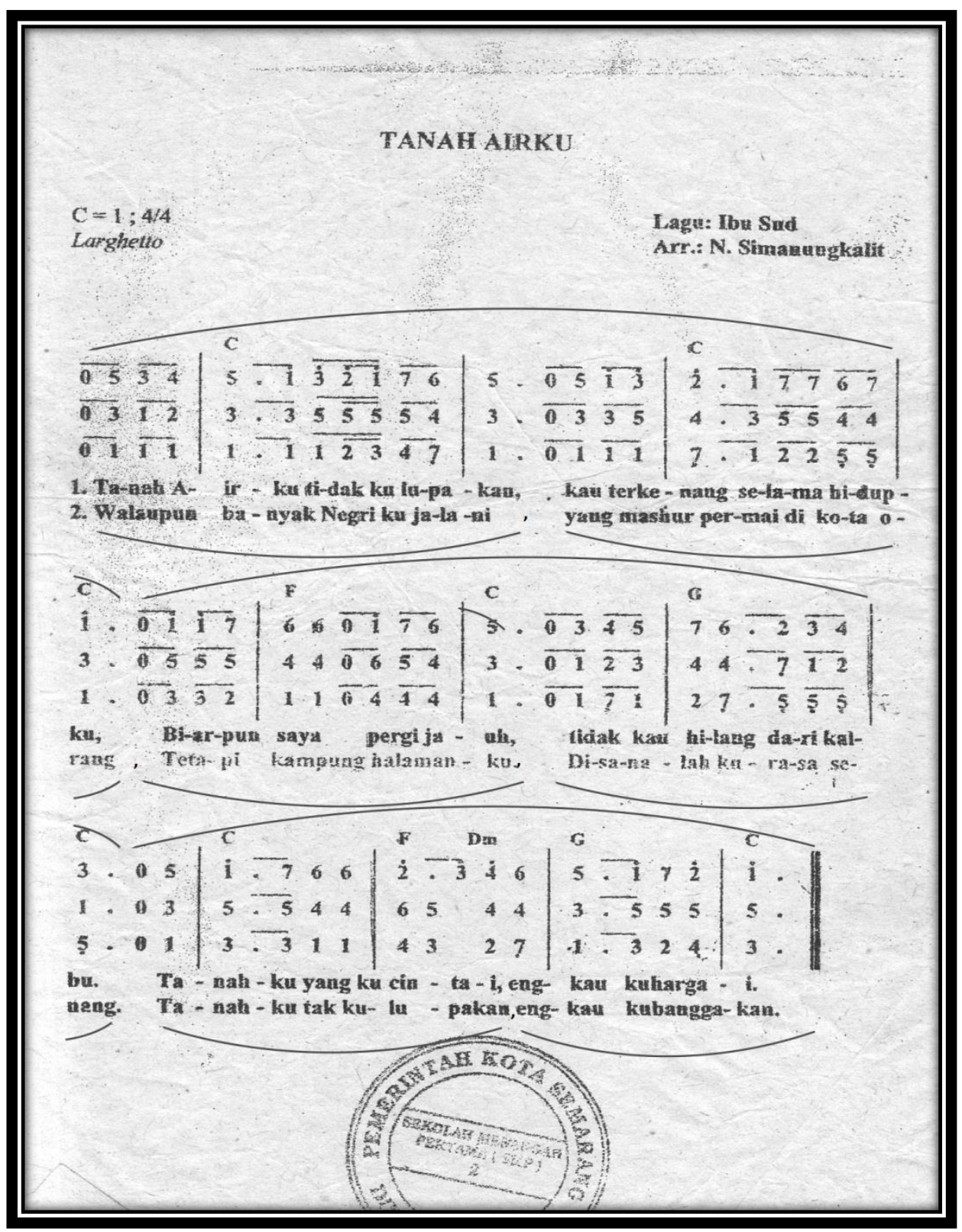

Contoh lagu tersebut diberikan oleh pelatih kepada siswa anggota paduan suara disertai dengan pemenggalan kalimat/ frasering yang ditandai dengan tanda koma (,). Phrasering adalah aturan pemenggalan kalimat yang baik dan benar sehingga mudah dimengerti, dengan demikian kalimat lagu tersebut dapat menyampaikan pesan dari sebuah lagu/karya kepada pendengar pada saat bernyanyi. Oleh karena itu, pelatih menganggap latihan frasering ini sangat 
penting diberikan kepada siswa anggota paduan suara. Pelatih menjelaskan kepada siswa apa itu frasering kemudian mempraktekannya dalam lagu yang sedang dipelajari bersama.

Pelatih menegaskan kepada siswa apabila mengambil nafas harus memperhatikan kalimat musik yang ada lewat tanda-tanda penulisan dalam partitur lagu seperti koma maupun titik. Kalimat bahasa (kalimat teks) yang perlu diperhatikan adalah makna syair keseluruhan sehingga dalam mencapai kesatuan kalimat selalu mendukung terhadap makna yang tersirat dalam syair yang ada. Hal esensi yang perlu diperhatikan dalam phrasering adalah mengenal titik atau koma, tanda titik atau koma merupakan tempat mengambil nafas. Dengan demikian tidak boleh mengambil nafas di luar tanda yang sudah diberikan agar keutuhan kalimat dan syair lagu dinyanyikan dapat tercapai dengan sempurna. Setelah siswa paham penjelasan mengenai frasering kemudian pelatih bersama-sama dengan siswa menerapkan frasering dalam lagu yang sedang dipelajari dengan mengajak siswa berdiskusi bersama untuk mencari pemenggalan kalimat yang tepat dalam lagu tersebut kemudian menyanyikannya secara bersama-sama.

Pengertian frasering yang di maksudkan oleh pelatih sama halnya seperti dalam landasan teori menurut Linggono (2008:108), frasering adalah pemenggalan kalimat musik menjadi bagian-bagian yang lebih pendek, tetapi tetap mempunyai kesatuan arti. Tujuan frasering adalah agar dapat memenggal kalimat musik lebih tepat sesuai dengan isi kalimat. Dengan demikian usaha untuk mengungkapkan suatu lagu dapat lebih mendekati kebenaran yang terkandung didalamnya sesuai dengan pesan lagu tersebut. 
Sebelum pelatih mengajarkan frasering, pelatih telah mengajarkan teknik pernapasan kepada siswa, karena teknik frasering ini juga berhubungan dengan teknik pernapasan. Jika pernapasan buruk dan tidak dilatih dengan baik akan berdampak bagi tidak tepatnya dalam pemenggalan kata dalam lagu dikarenakan napas yang tidak kuat. Hal ini didukung dari pendapat Suharto (2009) yang mengatakan bahwa frasering adalah teknik pemenggalan kalimat lagu. Teknik ini terkait juga dengan teknik pernapasan, dan interpretasi. Teknik ini penting karena salah menginterpretasi, terutama dalam pemenggalan kalimat, akan mengurangi keindahan termasuk juga maknanya.

Latihan frasering yang diterapkan pelatih dapat membantu siswa anggota paduan suara untuk dapat bernyanyi dengan baik sehingga dapat menyampaikan isi dan makna dari lagu yang diajarkan. Metode diskusi yang diterapkan pelatih dalam mengajarkan frasering melatih siswa untuk berpikir dan mencari tahu sehingga terangsang dalam belajar. Selain itu, dengan metode latihan atau praktek secara langsung, siswa menjadi paham dan mengerti cara menyanyikan lagu dengan frasering yang tepat.

\subsubsection{Latihan Interpretasi dan Pembawaan Lagu}

Proses pembelajaran selanjutnya adalah latihan interpretasi dan pembawaan lagu. Setelah lancar dalam membaca notasi dan syair lagu, anggota paduan suara berlatih penguasaan lagu yang akan dinyanyikan. Unsur dasar untuk dapat menjiwai sebuah lagu terdapat dalam partitur lagu yang didalamnya memiliki tanda dinamik dan tempo. Pelatih memberikan contoh dengan 
menyanyikan lagu yang diberi tekanan, dinamika lagu sesuai dengan tanda-tanda dalam teks tersebut.

Anggota paduan suara mengikuti apa yang diajarkan oleh pelatih sesuai dengan contoh yang diberikan. Selain itu bukan hanya tanda dinamika saja melainkan juga mengenai pemahaman terhadap lagu tersebut, makna dan maksud dari lagu agar pesan dari syair dapat tersampaikan oleh pendengar. Pada pemahaman syair pelatih memberi kesempatan siswa untuk melakukan diskusi serta tanya jawab mengenai syair yang terkandung dalam lagu yang diajarkan.

Dalam hal ini pelatih menerapkan metode diskusi dan tanya jawab. Pelatih bersama semua anggota paduan suara bersama-sama mencari tau makna serta maksud dari syair lagu tersebut agar isi dan makna dari lagu tersampaikan. Hal ini dilakukan agar siswa terangsang untuk belajar, memiliki sikap terbuka, berani mengungkapkan ide dan pendapat.

Setelah siswa sudah memahami arti dan maksud yang terkandung dalam lagu maka siswa memiliki gambaran bagaimana lagu akan dibawakan. Selanjutnya pelatih pun mengajarkan ekspresi, mimik wajah, maupun gerakan dalam membawakan atau menyanyikan lagu. Setelah semua proses interpretasi ini dilakukan, selanjutnya anggota paduan suara mencoba untuk menerapkan apa yang sudah dipelajari untuk dinyanyikan dalam paduan suara.

Dari pembahasan diatas dalam pembelajaran mengenai latihan intepretasi dan pembawaan lagu, pelatih menerapkan metode demostrasi yaitu, pelatih memberikan contoh mengenai dinamika lagu sesuai dengan tanda-tanda dalam teks lagu yang sedang dipelajari dengan cara pelatih menyanyikan lagu tersebut, 
kemudian siswa anggota paduan suara mempraktekannya. Sedangkan metode diskusi dan tanya jawab yaitu mengenai makna dan arti dari syair pada lagu.

Pelatih menganggap latihan ini sangat penting untuk mendapatkan hasil yang maksimal dalam bernyanyi paduan suara supaya pesan dan maksud dari lagu tersampaikan oleh pendengar. Selain itu latihan intrepretasi ini dapat menunjang penampilan paduan suara agar terlihat baik dan kompak. Hal ini didukung dari landasan teori menurut Suharto (2009), teknik interpretasi dan pembawaan lagu cukup penting terutama berkaitan dengan bagaimana lagu itu dinyanyikan. Pesan lagu, karakter lagu, sampai pada bagian-bagian lagu (termasuk tanda-tanda ekspresi atau dinamik) harus bisa ditangkap oleh pelatih dengan baik. Penafsiran dan pengungkapan yang baik akan membawa penampilan paduan suara lebih baik pula. Pelatih harus bekerja keras untuk mencermati seluruh isi partitur lagu dan menerapkannya dalam paduan suaranya.

Dengan demikian, cara dan metode yang diterapkan dalam pembelajaran interpretasi dan pembawaan lagu oleh pelatih membuat siswa anggota paduan suara memiliki penjiwaan yang baik dan kompak dalam bernyanyi.

\subsubsection{Latihan Keterpaduan (Blend)}

Untuk mendapatkan keterpaduan pada paduan suara SMP Negeri 2 Semarang, pelatih memberikan motivasi dan menganalisis lagu yang akan dinyanyikan dan memberikan contoh atau mengajarkan kepada siswa anggota paduan suara agar dapat menyanyikannya dengan penghayatan. Selain itu pelatih melatih ketepatan nada siswa anggota paduan suara dengan melakukan pemanasan terlebih dahulu sebelum bernyanyi (vokalizi). 
Pelatih menekankan untuk mendapatkan faktor keterpaduan dalam paduan suara SMP Negeri 2 Semarang dengan cara tidak menjolkan individu, tetapi suara harus sama dengan tingkat dinamik yang seragam, warna suara, bentuk mulut/ mimik yang sama. Hal ini ssependapat dengan teori menurut Sitompul (1986:45), beberapa syarat untuk mencapai keterpaduan adalah: tinggi rendah nada (pitch), kualitas suara yang baik, pengguna register yang sama, pengguna vibrato yang terkendali, dan tingkat dinamik yang sama.

Penyamaan dinamik tersebut supaya tercipta keterpaduan dalam kelompok paduan suara. Pelatih memberi penjelasan kepada siswa anggota paduan suara yang pada umumnya masih cenderung untuk menonjolkan diri, dengan bernyanyi paling keras, tentunya hal tersebut merupakan suatu yang salah dalam bernyanyi paduan suara dan disinilah peran pelatih untuk memberi arahan dan masukan yang benar. Dengan demikian dalam pembelajaran keterpaduan/ blend, pelatihlah yang aktif dalam mecapai tujuan untuk terciptanya keterpaduan.

\subsubsection{Latihan Keseimbangan (Balance)}

Selain latihan blend, perlu juga diperhatikan adanya keseimbangan antara kekuatan suara dan iringan musiknya. Oleh sebab itu, cara pelatih adalah dengan mengatur penempatan barisan ketika bernyanyi, perubahan formasi dari paduan suara itu untuk mendapatkan barisan yang seimbang menurut pelatih. Jumlah sopran, alto dan mezozopran pun harus seimbang supaya tercipta keseimbangan.

Untuk mencapai keseimbangan/ balance siswa diarahkan untuk praktek dalam menyanyikan lagu yang telah diajarkan. Kemudian pelatih mengoreksi tentang ketepatan irama, kekuatan suara, serta warna suara, hal itu bertujuan untuk 
menghindari tidak ada kelompok suara yang paling dominan suaranya. Dengan demikian akan tercapai keseimbangan dalam mengungkapkan ekspresi, tempo, dinamik, volume suara dan gaya penyajiannya. Pelatih mengoreksi bahwa tiaptiap kelompok dalam membawakan lagu sesuai dengan porsi yang telah diajarkan, tidak ada yang terlalu dominan diantara kelompok lainnya agar tercipta keseimbangan antar keelompok paduan suara.

Hal ini sependapat dengan landasan teori menurut Suharto (2009), Faktor keseimbangan tidak lepas dari blend. Jika dalam blend adalah untuk menciptakan kesamaan atau kepaduan antar personil dan kelompok suara maka teknik keseimbangan ini untuk menciptakan keseimbangan antar kelompok suara. Keseimbangan ini untuk menghindari tidak ada kelompok suara yang paling dominan suaranya. Keseimbangan ini bisa meliputi kekuatan, warna, dinamik, irama, dan sebagainya.

Dengan demikian, disini pelatih paduan suara SMP Negeri 2 memiliki peranan penting dalam mengatur keseimbangan dari suara sopran, mezzosopran dan alto supaya terciptanya paduan suara yang baik dan dapat dinikmati oleh pendengar.

\subsubsection{Tahap Evaluasi}

Tahap terakhir yang dilakukan oleh pelatih dalam proses pembelajaran ekstrakurikuler paduan suara di SMP Negeri 2 Semarang yaitu tahap evaluasi. Evaluasi adalah komponen yang berfungsi untuk mengetahui apakah tujuan yang telah ditetapkan telah tercapai atau belum, juga bisa berfungsi sebagai umpan balik untuk perbaikan strategi yang telah ditetapkan, Suharto (2015:13). Menurut 
Fathurrohman (2007:14-15), evaluasi memiliki tujuan secara umum, yakni: (1) Mengumpulkan data-data yang membuktikan taraf kemajuan murid dalam mencapai tujuan yang diharapkan. (2) Memungkinkan pendidik/ guru menilai aktivitas/ pengalaman yang didapat siswa dalam pembelajaran. (3) Menilai metode mengajar yang dipergunakan.

Pelatih melakukan tahap evaluasi untuk mengetahui sejauh mana para siswa memperoleh ilmu yang telah diberikan dan juga untuk mengetahui bagaimana keberhasilan pelatih dalam mengelola ekstrakurikuler paduan suara di SMP Negeri 2 Semarang. Dengan demikian pelatih dapat menilai apakah materi dan tata cara yang digunakan dalam melatih siswa sudah tepat atau masih perlu dirubah untuk mendapatkan hasil pelatihan yang lebih baik.

Pada tahap evaluasi yang dilakukan pelatih paduan suara SMP Negeri 2 Semarang yaitu pelatih mengadakan tanya jawab dari kesulitan yang dihadapi siswa anggota paduan suara dalam menerima materi lagu yang dinyanyikan, dan kemudian mengadakan perbaikan saat itu juga jika terjadi kesalahan. Pelatih mengamati dan mengevaluasi keberhasilan maupun kekurangan dalam latihan, selanjutnya dalam tahap ini pelatih mengadakan langkah-langkah untuk mengulang latihan bagi siswa atau kelompok yang dianggap melakukan kesalahan dalam menyanyikan lagu ataupun dalam notasinya, sekaligus memberikan pengarahan dan motivasi.

Selain itu, pelatih juga melakukan penilaian di setiap akhir semaster. Bentuk evaluasi dalam kegitan ekstrakurikuler dengan cara membentuk kelompok kemudian menampilkan dengan menyanyikan lagu sesuai dengan partitur yang 
telah diajarkan. Aspek-aspek yang diamati oleh pelatih dalam penilaian pada penelitian ini antara lain: (1) Intonasi, (2) artikulasi, (3) Harmonisasi (4) Kepribadian dan (5) Kedisipinan. Penilaian ini menggunakan skala rentang dengan empat kategori nilai, yaitu: sangat baik dengan nilai 4, baik dengan nilai 3, cukup dengan nilai 2, dan kurang dengan nilai 1 . Format penilaian unjuk kerja untuk menilai kemampuan bernyanyi siswa dalam Paduan Suara dilakukan melalui pembagian kelompok.

Pelatih membagi siswa anggota paduan suara menjadi beberapa kelompok. Masing-masing kelompok terdiri dari 9 orang yang mewakili 3 suara Sopran, 3 mezosopran, 3 dan alto. Kelompok tersebut menyanyikan materi lagu yang telah diajarkan sesuai dengan notasi range suara masing-masing. Penilaian dilakukan secara individu sesuai dengan kriteria penilaian yang sudah di tentukan, apabila satu kelompok dapat menyanyikan lagu secara sempurna, maka kelompok tersebut masing-masing anak diberikan nilai 4.

Berikut ini contoh pedoman penilaian dalam pembelajaran ekstrakurikuler Paduan Suara SMP Negeri 2 Semarang.

Tabel 1 Pedoman Penilaian Unjuk Kerja

(Dokumen Ines, Januari 2017)

\begin{tabular}{|l|l|l|l|l|c|c|c|c|}
\hline \multirow{2}{*}{ No } & \multirow{2}{*}{ Nama } & \multirow{2}{*}{ Kelas } & Intonasi & $\begin{array}{c}\text { Artiku } \\
\text { lasi }\end{array}$ & $\begin{array}{c}\text { Harmo } \\
\text { nisasi }\end{array}$ & $\begin{array}{c}\text { Kepri } \\
\text { badia } \\
\mathrm{n}\end{array}$ & $\begin{array}{c}\text { Kedispl } \\
\text { inan }\end{array}$ & $\begin{array}{c}\text { Nilai } \\
\text { Akhir }\end{array}$ \\
\hline & & & & & & & & \\
\hline
\end{tabular}


Petunjuk Penskoran :

Skor akhir menggunakan skala 1 sampai 4. Perhitungan skor akhir menggunakan rumus :

$\frac{\text { skor diperoleh }}{\text { skor maksimal }}$ X $4=$ skor akhir

Peserta didik memperoleh nilai :

A (sangat baik) : skor dari 3.3 sampai dengan 4.00

B (baik) : skor dari 2.3 sampai dengan 3.2

C (cukup) : skor dari 1.3 sampai dengan 2.2

D (kurang) : skor kurang dari 1.3

Contoh:

Nama siswa Wulandari suara sopran, pada aspek (1) memperoleh skor 4; aspek (2) memperoleh skor 3; aspek (3) memperoleh skor 4; aspek (4) memperoleh skor 4; dan aspek (5) memperoleh skor 3

Jumlah skor yang dimiliki : $3+3+3+4+3=16$

Skor maksimal : $4+4+4+4+4=20$

Skor akhir $=3.2$

Maka peserta didik akan memperoleh nilai B , karena $2.3<3.2<4.0$

Kemudian nilai dari hasil evaluasi tersebut akan dimasukan ke dalam nilai raport siswa. Siswa SMP Negeri 2 Semarang diwajibkan untuk mengikuti kegiatan ekstrakurikuler maksimal 2 ektrakurikuler. Nilai ektrakurikuler ini diambil pada tiap akhir semester dengan dilakukan penilaian seperti yang dijelaskan diatas, dan hasilnya akan di cantumkan pada nilai raport ekstrakurikuler yang diikuti. Selain itu juga siswa berlomba-lomba untuk 
mendapatkan nilai terbaik karena dengan nilai yang baik juga menjadi bahan pertimbangan bagi pelatih untuk memilih siswa anggota paduan suara yang akan diutus menjadi peserta lomba mewakili sekolah. Hal tersebut memicu peserta paduan suara untuk berlatih dengan giat agar terpilih untuk mengikuti lomba paduan suara.

Hal ini diperkuat dari pendapat salah satu siswi anggota paduan suara yang telah diwawancarai pada tanggal 16 januari 2017, bernama Keysha Diva Azzahra. Ujarnya, dalam mengikuti ekstrakurikuler paduan suara selain untuk menambah pengalaman di bidang olah vokal, dia juga mengatakan agar terpilih dan mengikuti lomba paduan suara yang mewakili sekolah. Dia juga menegaskan dengan mengikuti lomba paduan suara yang mewakili sekolah menjadi suatu kebanggaan tersendiri bagi dirinya dan memotivasi untuk belajar lebih giat dalam bernyanyi secara paduan suara melalui ekstrakurikuler paduan suara tersebut.

Menurut peneliti, pada proses evaluasi pelatih telah melakukan evaluasi sesuai dengan teori. Proses evaluasi yang dilakukan oleh pelatih untuk mengukur sejauh mana materi dapat diterima oleh siswa. Dalam tahap evaluasi ini pelatih melakukan tanya jawab mengenai kesulitan siswa dan melakukan perbaikan, selain itu pelatih juga mengadakan penilaian.

\subsection{Komponen-Komponen Pembelajaran}

Proses pembelajaran dapat berjalan dengan baik apabila ada komponen yang mendukung. Berdasarkan landasan teori menurut Djamarah, komponenkomponen yang mendukung dalam pembelajaran yaitu : tujuan, siswa, guru, materi, metode, alat bantu, dan evaluasi, demikian juga pembelajaran 
ekstrakurikuler paduan suara yang dilaksanakan di SMP Negeri 2 Semarang. Data ini diperoleh melalui wawancara terhadap pelatih paduan suara bapak Sudaryono S. Pd dan kepala SMP Negeri 2 Semarang bapak Teguh Waluyo S.Pd, MM pada tanggal 10 Januari 2017 serta observasi pada tanggal 16 Januari 2017.

Berikut penjelasan mengenai komponen-komponen pembelajaran ekstrakurikuler Paduan Suara di SMP Negeri 2 Semarang :

\subsubsection{Komponen Tujuan}

Salah satu komponen yang memiliki kedudukan paling awal adalah tujuan yang ingin dicapai. Menurut Fathurrohman (2007:13), tujuan dalam pendidikan dan pengajaran merupakan suatu cita-cita yang bernilai normatif. Sebab dalam tujuan terdapat sejumlah nilai yang harus ditanamkan kepada anak didik. Nilainilai itu nantinya akan mewarnai cara anak didik bersikap dan berbuat dalam lingkungan sosial, baik di sekolah maupun di luar sekolah.

Begitupun juga dengan data yang diperoleh melalui hasil wawancara dengan Kepala SMP Negeri 2 Semarang yaitu bapak Teguh Waluyo S.Pd, MM bahwa SMP Negeri 2 Semarang juga memiliki tujuan dalam pembelajaran yaitu mengembangkan potensi, bakat dan minat secara optimal dalam bernyanyi agar siswa dapat bernyanyi dengan baik dan benar sesuai dengan teknik-teknik yang diajarkan secara paduan suara, melatih kekompakan anggota paduan suara, kepekaan dan terhadap nada.

Dengan bernyanyi dalam paduan suara maka akan terbentuk hati yang senang, mengungkapkan ekspresi, melatih rasa percaya diri peserta didik, kerjasama antar teman. Kemudian tidak hanya itu dengan adanya kegiatan 
ekstrakurikuler paduan suara siswa dapat mengembangkan kepribadian diri dan membangun rasa sosialisasi yang tinggi dengan orang lain. Maka dari itu seorang pelatih ekstrakurikuler paduan suara harus memiliki beberapa kemampuan dalam memilih bahan atau materi pengajaran yang sesuai dengan tujuan, memilih media yang tepat serta menentukan strategi atau metode dan teknik yang tepat pula.

\subsubsection{Komponen Siswa (Anggota Paduan Suara)}

Data siswa ekstrakurikuler Paduan Suara SMP Negeri 2 Semarang diperoleh melalui hasil observasi pengamatan langsung pada saat proses pembelajaran, hasil wawancara dengan pelatih paduan suara bapak Sudaryono,S.Pd serta dokumentasi. Dalam landasan teori menurut Tri Ani (2012:160) subyek belajar dalam sistem pembelajaran merupakan komponen utama karena berperan sebagai subyek sekaligus obyek. Sebagai subyek karena peserta didik adalah individu yang melakukan proses belajar-mengajar. Sebagai obyek karena kegiatan pembelajaran diharapkan dapat mencapai perubahan perilaku pada diri subyek belajar. Untuk itu dari pihak peserta didik diperlukan partisipasi aktif dalam kegiatan pembelajaran.

Begitu pula dengan siswa anggota paduan suara SMP Negeri 2 Semarang yang berperan sebagai subyek yang melakukan proses belajar mengajar melalui ekstrakurikuler paduan suara, sedangkan sebagai objek, siswa anggota paduan suara dengan mengikuti ekstrkurikuler paduan suara, siswa lebih berperan aktif dalam pengembangan bakat dalam diri siswa khususnya dalam olah vokal, selain itu banyak nilai positif yang dapat membangun sikap dan mental siswa. 
Dari hasil pengamatan, siswa anggota paduan suara SMP Negeri 2 Semarang begitu antusias dalam mengikuti kegiatan proses pembelajaran paduan suara, dapat dilihat dari semangat siswa dalam mengikuti pembelajaran ekstrakurikuler paduan suara serta rasa keingintahuan siswa dalam menerima materi dari pelatih. Sedangkan wawancara yang diperoleh dari pelatih paduan suara tanggapan siswa dalam mengikuti ektrakurikuler paduan suara sangat positif, hal ini dilihat dari banyaknya jumlah siswa yang mengikuti ekstrakurikuler paduan suara serta kesidiplinan siswa dalam mengikuti kegiatan ekstrakurikuler paduan suara. Anggota ekstrakurikuler paduan suara merupakan faktor yang menentukan dalam kegiatan belajar mengajar. Siswa yang aktif serta memiliki semangat yang tinggi merupakan modal utama keberhasilan dalam pelaksanaan pembelajaran ekstrakurikuler di sekolah, murid yang mengikuti ekstrakurikuler dibina dan diarahkan oleh pelatih dalam menghadapi setiap kesulitan mengenai materi pembelajaran yang diterapkan.

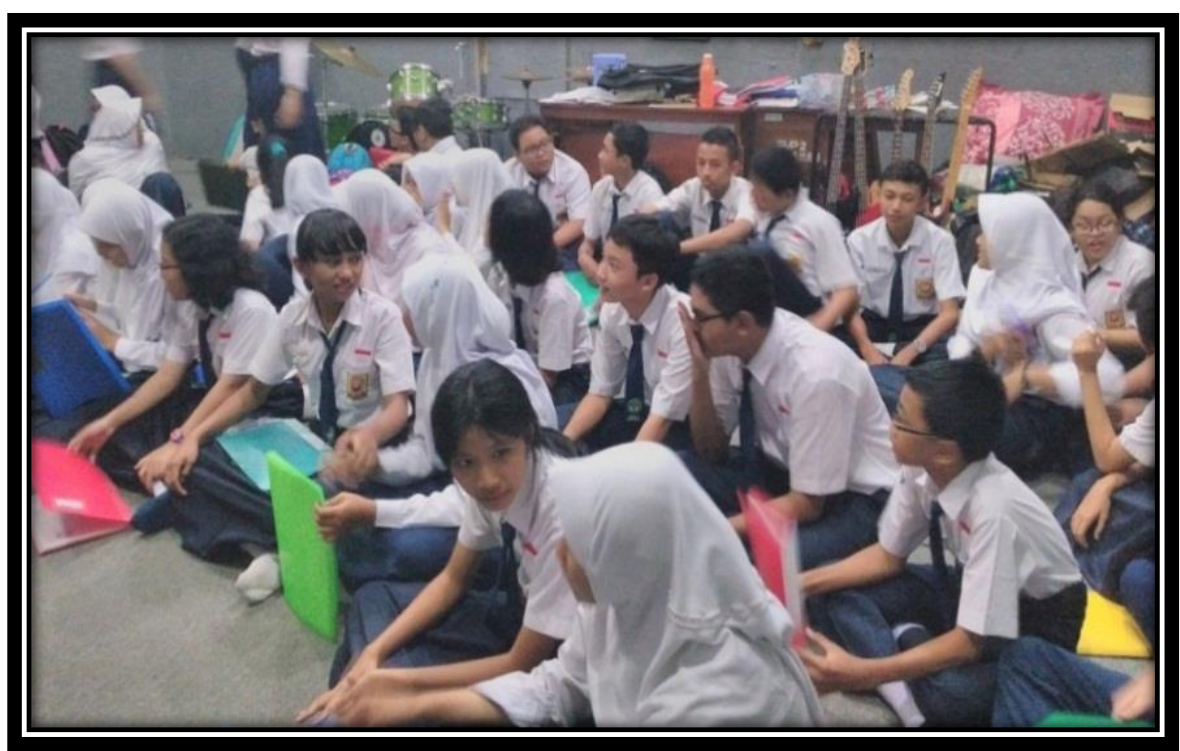

Gambar 15. Siswa anggota paduan suara ( Foto: Ines, 2017) 
Dari data dokumentasi yang diperoleh anggota ekstrakurikuler paduan suara terdiri dari 136 siswa dengan jumlah siswi perempuan 105 dan siswa lakilaki yang terdiri dari 31 siswa kelas VII, VIII. (Tabel daftar siswa terlampir).

\subsubsection{Komponen Guru/ Pelatih Ekstrakurikuler Paduan Suara}

Data mengenai pelatih paduan suara di SMP Negeri 2 Semarang ini diperoleh dari hasil wawancara dengan kepala sekolah mengenai kinerja pelatih dan melalui pengamatan langsung atau observasi yang peneliti lakukan pada saat proses pembelajaran ekstrakurikuler paduan suara berlangsung. Menurut Hamalik (2008:9) pendidik merupakan suatu komponen yang penting dalam penyelenggaraan pendidikan, yang bertugas menyelenggarakan kegiatan mengajar, melatih, meneliti, mengembangkan, mengelola, dan atau memberikan pelayanan teknis dalam bidang pendidikan. Salah satu unsur tenaga kependidikan adalah tenaga pendidik/ tenaga pengajar yang tugas utamanya adalah mengajar.

Begitu pula pada pelatih ekstrakurikuler paduan suara di SMP Negeri 2 Semarang yang juga melakukan kegiatan mengajar, melatih, meneliti, mengembangkan, mengelola ekstrakurikuler paduan suara. Dari hasil wawancara dengan kepala sekolah SMP Negeri 2 Semarang bapak Teguh Waluyo S.Pd,MM, proses pembelajaran ekstrakurikuler paduan suara SMP Negeri 2 Semarang di bimbing oleh 1 orang pengajar yaitu seorang guru musik sekolah tersebut yang bernama bapak Sudaryono S. Pd.

Beliau adalah lulusan Pendidikan Seni Musik dari Universitas Negeri Semarang. Beliau mengajar ekstrakurikuler paduan suara di SMP Negeri 2 Semarang sejak tahun 2003. Sebagai pelatih ekstrakurikuler paduan suara bapak 
Sudaryono S. Pd merupakan guru yang tanggung jawab dan disiplin dalam dalam membimbing siswa dan memiliki andil yang besar terhadap kemajuan serta prestasi ektrakurikuler paduan suara di sekolah tersebut.

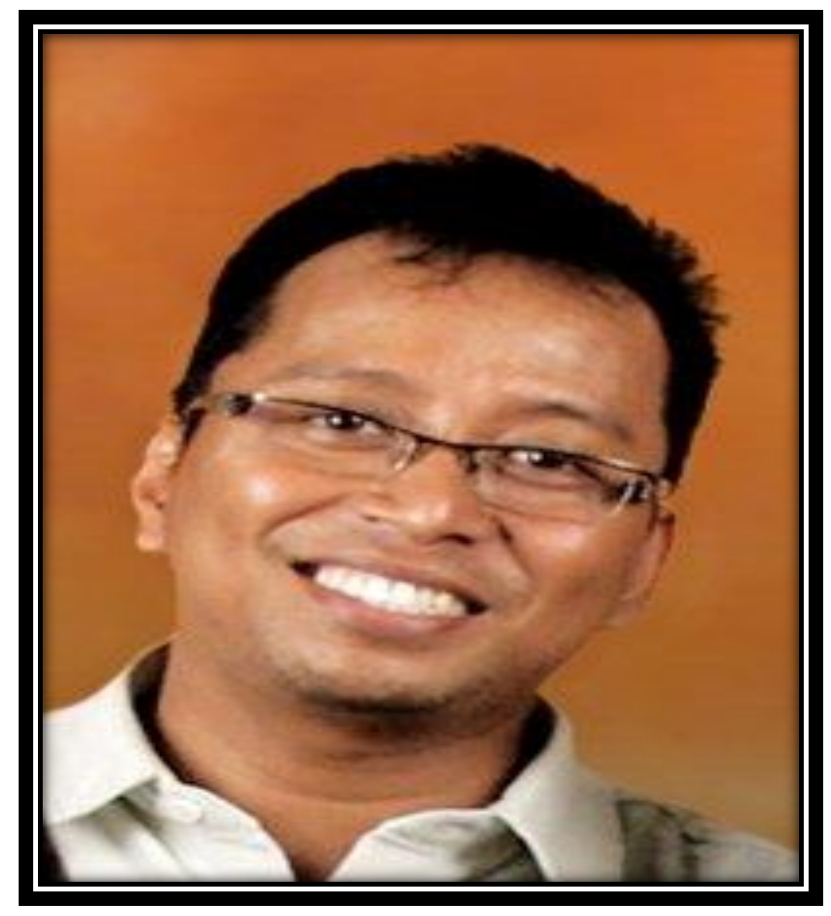

Gambar 16. Sudaryono S. Pd, pelatih paduan suara ( Foto: Ines, 2017)

Sedangkan dari hasil observasi di lapangan pada tanggal 16 Januari 2017, pelatih paduan suara yaitu bapak Sudaryono S. Pd merupakan sosok yang ramah dan akrab terhadap peserta didik/ anggota paduan suara namun tetap tegas dalam menyampaikan materi. Beliau juga merupakan sosok yang disiplin, hal itu dilihat ketika beliau menerapkan tata tertib dalam mengikuti ekstrakurikuler paduan suara. Ketika proses pembelajaran ektrakurikuler paduan suara terdapat peserta yang datang terlambat tanpa suatu alasan yang jelas, siswa tersebut tidak diperbolehkan mengikuti proses pembelajaran. Namun jika alasannya jelas peserta anggota paduan suara tersebut di beri hukuman yaitu dengan menyanyikan salah 
satu lagu Nasional dengan teknik vokal yang telah diajarkan. Jadwal pembelajarannya pun harus tepat waktu. Hal itu dilakukan untuk melatih kedisiplinan serta tanggung jawab siswa anggota paduan suara.

Dalam akhir pembelajaran, pelatih ekstrakurikuler paduan suara selalu mengadakan evaluasi dengan cara memerintahkan anggota paduan suara untuk menyanyikan materi yang telah diajarkan dan menanyakan mengenai kesulitan siswa dalam menerima materi. Pelatih paduan suara SMP Negeri 2 Semarang dalam membawakan materi dapat dipahamai oleh anggota, karena dalam pengelolaan pada saat proses belajar mengajar sangat variatif. Sebagai contoh pada saat mengajarkan nilai ketukan, pelatih mengibaratkan nilai ketukan dengan tepukan tangan. Dalam pembelajaran yang berlangsung, beliau mampu menciptakan suasana belajar yang menyenangkan sehingga siswa tidak jenuh dan bosan.

\subsubsection{Komponen Metode Pembelajaran}

Penerapan metode paduan suara SMP Negeri 2 Semarang oleh pelatih tentu saja menentukan berhasil atau tidaknya paduan suara di SMP Negeri 2 Semarang. Pemilihan metode mengajar sangat penting dalam pembelajaran ekstrakurikuler paduan suara. Untuk mencapai tujuan yang diharapkan pelatih didalam pembelajaran harus dapat memilih serta menentukan metode yang sesuai dengan materi yang diberikan dan kemampuan siswa. Dengan pemilihan metode yang sesuai dengan materi yang dapat diberikan maka akan berdampak positif pada anak didik, yaitu dapat mengikuti pembelajaran ekstrakurikuler paduan suara dengan baik dan benar dan juga dengan perasaan yang senang. 
Hal ini didukung oleh teori menurut Djamarah (dalam Djamarah 1996:53) metode adalah suatu cara yang dipergunakan untuk mencapai tujuan yang telah ditetapkan. Dalam kegiatan belajar mengajar, metode diperlukan oleh guru dan penggunaanya bervariasi sesuai dengan tujuan yang ingin dicapai setelah pengajaran berakhir. Seorang guru tidak dapat melaksanakan tugasnya bila dia tidak menguasai satu pun metode mengajar yang telah dirumuskan dan dikemukakan para ahli psikologi dan pendidikan.

Dari hasil wawancara oleh pelatih paduan suara bapak Sudaryono S pada tanggal 10 Januari 2017 serta observasi pada tanggal 16 januari 2017, dalam proses pembelajaran paduan suara di SMP Negeri 2 Semarang pelatih menggunakan metode ceramah, demonstrasi, tanya jawab, tutor sebaya, dan metode drill/ latihan. Berikut penjelasan mengenai metode - metode tersebut :

\subsubsection{Metode Ceramah}

Di awal kegiatan pelatih terlebih dahulu memberikan penjelasan dengan metode ceramah mengenai materi teori musik cara mengenal dan membaca notasi, menerangkan tentang melodi lagu serta teknik yang di gunakan dalam bernyanyi. pelatih menerapkan metode ceramah ini dengan penuturan secara lisan terhadap kelasnya untuk memperjelas uraian yang disampaikan kepada siswa. Selain itu, metode ceramah diterapkan pelatih untuk membangkitkan motivasi para anggota paduan suara, memperjelas bagian materi yang dirasa sulit, mengupas dan memperluas materi. 


\subsubsection{Metode Demonstrasi}

Pelatih menggunakan metode demonstrasi dalam latihan. Pada metode demonstrasi dimaksud adalah pelatih memberikan contoh langsung bagaimana cara menyanyi dengan teknik vokal yang baik dan benar, diantara teknik pernafasan, artikulasi, frasering dan sebagainya. Selain itu pelatih juga mengajarkan mengenai dinamika dalam bernyanyi sesuai dengan partitur yang ada. Latihan ini bertujuan supaya anggota paduan suara lebih jelas untuk mengaplikasikannya dalam bernyanyi dan dapat menyanyikan secara langsung sesuai contoh yang sudah diberikan oleh pelatih secara benar dan lancar.

\subsubsection{Metode Tanya Jawab}

Setelah pengajar menerangkan materi pelajaran, kemudian pengajar bertanya kepada para siswa tentang materi yang telah disampaikan. Hal ini dimaksudkan untuk mngetahui sejauh mana siswa memahami atau menangkap materi yang telah diberikan. Selain diberi pertanyaan siswa juga diberi kesempatan untuk bertanya jika mereka belum memahami materi yang telah disampaikan atau pertanyaan- pertanyaan diluar materi yang telah disampaikan. Hal ini dimaksudkan sejauh mana peserta didik memahami atau menyerap materi pembelajaran yang telah diberikan oleh pelatih.

Metode tanya jawab juga digunakan apabila memungkinkan terjadinya dialog antara guru/ pelatih dan siswa peserta ekstrakurikuler paduan suara untuk memecahkan suatu permasalahan dalam pembelajaran. Metode ini digunakan untuk merangsang siswa untuk aktif agar siswa dalam belajar dapat menuangkan 
ide di dalam pembelajaran serta belajar mengemukaan pendapatnya dalam diskusi dalam kelompok belajar.

\subsubsection{Metode Tutor Sebaya}

Pelatih ekstrakurikuler paduan suara di SMP Negeri Semarang juga menggunakan tutor sebaya yaitu suatu metode pembelajaran yang dilakukan dengan cara memberdayakan siswa yang memiliki daya serap yang tinggi dari kelompok siswa itu sendiri untuk menjadi tutor bagi teman-temannya, dimana siswa yang menjadi tutor bertugas untuk memberikan materi belajar dan latihan kepada teman-temannya yang belum paham terhadap latihan yang diberikan guru dengan dilandasi aturan yang telah disepakati bersama dalam kelompok tersebut.

Bantuan yang diberikan teman-teman sebaya pada umumnya dapat memberikan hasil yang cukup baik. Dalam interaksi tidak menutup kemungkinan antar siswa satu dengan siswa yang lain saling membantu dan membutuhkan dalam pembelajaran untuk memperoleh hasil belajar yang lebih baik. Dalam pembelajaran paduan suara dibagi menjadi beberapa suara yaitu sopran, mezosopran dan alto. Dari semua anggota paduan suara yang sudah di bagi dengan wilayah suara masing-masiang dikelompokan menurut pembagian wilayahnya masing-masing. Sopran dengan sopran, mezzosopran dengan mezzosopran, alto dengan alto. Setelah itu dari tiap-tiap kelompok bagi siswa yang dirasa menonjol dalam vokal memberikan tutor kepada teman-temannya sesuai dengan jangkauan wilayah suara masing-masing. 


\subsubsection{Metode Latihan/ Drill}

Metode drill digunakan pelatih untuk melatih keterampilan siswa dalam bernyanyi agar siswa mengerti teknik bernyanyi yang benar sehingga dapat mempraktekannya. Latihan yang dilakukan secara berulang-ulang akan menghasilkan keterampilan yang maksimal, sehingga siswa bisa menyanyikan lagu tanpa melihat partitur secara bersama-sama. Siswa dilatih secara berulangulang membaca notasi, tangga nada, kemudian menyanyikan syair secara berulang-ulang dengan dinamika, tempo, frasering, nada yang tepat.

Dapat disimpulkan bahwa metode-metode yang diterapkan oleh pelatih merupakan cara pelatih dalam menyajikan bahan pelajaran kepada siswa anggota paduan suara agar dapat memudahkan pelaksanaan pembelajaran esktrakurikuler paduan suara guna mencapai tujuan yang ditentukan. Setiap metode-metode yang diterapkan memiliki pengaruh menurut kegunaan masing-masing dalam pembelajaran ekstrakurikuler paduan suara. Metode yang memiliki pengaruh besar terhadap pembelajaran yaitu metode tutor sebaya dan metode latihan/ drill. Karena dalam penerapan tutor sebaya peserta didik dilatih untuk mandiri, dewasa dan punya rasa setia kawan yang tinggi. Metode pembelajaran tutor sebaya ini mempunyai tujuan penting dalam kelompok, dapat melatih tanggung jawab individu dan memberikan pengajaran kepada peserta didik untuk saling membantu satu sama lain dan saling mendorong untuk melakukan usaha yang maksimal. Tanpa harus selalu bergantung oleh pelatih. Disinilah peran pelatih sebagai pembimbing agar penerapan metode tutor sebaya tearah dengan baik supaya tercipta tujuan yang diinginkan. Sedangkan dalam metode latihan/ drill juga 
berpengaruh besar dalam mencapai tujuan karena dapat melatih keterampilan siswa anggota paduan suara SMP Negeri 2 Semarang dalam berolah vokal. Karena paduan suara merupakan suatu keterampilan bernyanyi dalam kelompok secara bersama-sama yang harus diasah terus menerus dengan latihan secara berulang-ulang. Tidak bisa dilakukan hanya dengan pemberian teori saja melainkan harus dengan praktek latihan agar keterampilan dapat terasah dengan maksimal.

\subsubsection{Komponen Alat Bantu}

Alat bantu yang digunakan dalam pembelajaran Paduan Suara di SMP Negeri 2 Semarang adalah keyboard Yamaha PSR 2100. Dari landasan teori menurut Suharto (2015:12) alat yang digunakan dalam pembelajaran merupakan segala sesuatu yang dapat digunakan dalam rangka mencapai tujuan pembelajaran. Dalam proses pembelajaran alat memiliki fungsi sebagai pelengkap untuk mencapai tujuan.

Seperti hal nya dalam ekstrakurikuler paduan suara yang menggunakan alat musik keyboard untuk membantu proses pembelajaran dalam mencapai tujuan. Alat musik keyboard digunakan pada saat latihan menyanyi, membantu pelatih untuk membunyikan nada-nada termasuk nada dasar apabila saat latihan anggota paduan suara mengalami kesulitan dalam ketepatan nada selain itu, alat bantu keyboard juga digunakan untuk membantu pada saat dilakukan pemanasan. 


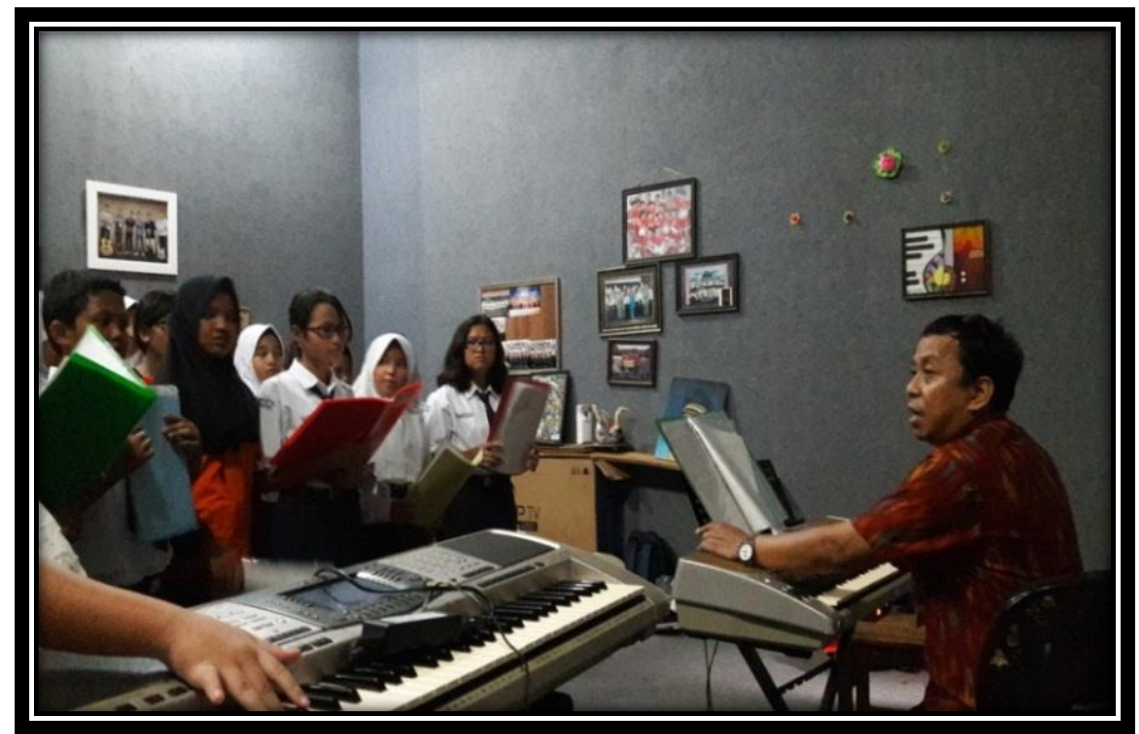

Gambar 15. Alat bantu keyboard ( Foto: Ines, 2017)

\subsubsection{Interaksi antara Pelatih dan Siswa}

Dalam suatu pembelajaran diperlukan adanya pendekatan individual, dalam hal ini pelatih harus mampu menyampaikan materi belajar kepada siswa yang di bimbingnya. Pendekatan pelatih pada siswa sangat diperlukan dengan tujuan agar pelatih dapat lebih memahami siswanya begitu pula dengan siswa supaya memahami pelatih agar materi yang diberikan oleh pelatih dapat diterima dengan baik.

Melalui observasi dilapangan yang dilakukan oleh peneliti pada tanggal 16 Januari 2017, interaksi yang terjalin antara pelatih dengan siswa anggota paduan suara berjalan dengan baik. Sebelum penyampaian materi pelatih bertanya sedikit mengenai materi yang selama ini sudah disampaikan kepada siswa. Hal tersebut bertujuan supaya pelatih dapat mengetahui sejauh mana tingkat daya serap siswa dalam menerima materi. Sebelum pembelajaran di mulai, pelatih berkomonuikasi 
terlebih dahulu dengan siswa untuk memberikan semangat/ motivasi dan memastikan bahwa siswa telah siap untuk mengikuti proses pembelajaran.

Di dalam pembelajaran ekstrakurikuler paduan suara, pelatih telah berperan sebagai demonstrator artinya pelatih mampu memperagakan apa yang diajarkannya kepada siswa sehingga siwa mampu mencontoh dan mempraktekan materi yang telah disampaikan. Selain itu dalam pembelajaran pelatih dapat mengelola kelas dengan baik, hal ini dapat dilihat dari keaktifan siswa dalam menerima materi. Pelatih tidak membuat siswa bosan dan takut karena pelatih memiliki selera humor agar siswa tidak tegang dalam menerima materi.

Pelatih mengajak siswa untuk berdialog dan menghargai pendapat siswa sehingga siswa merasa dihargai keberadaannya. Pelatih juga menguasai \& menjelaskan materi dengan baik dan dimengerti oleh siswa serta mau memaparkan kembali ketika ada siswa yang belum jelas/ belum paham. Dalam pembelajaran praktek bernyanyi pada paduan suara pelatih menggunakan metode dan teknik yang dapat dicerna oleh siswa. Hal tersebut menciptakan suasana kelas yang kondusif dan membuat interaksi antara pelatih dan siswa dapat terjalin dengan baik sehingga siswa pun dalam menerima pembelajaran sangat antusias dan aktif.

\subsection{Faktor Pendukung dan Penghambat}

Didalam segala usaha mencapai suatu keberhasilan tertentu terdapat faktor yang mempengaruhi baik itu yang bersifat pendukung maupun yang bersifat penghambat. Demikian juga dengan proses pembelajaran paduan suara SMP Negeri 2 Semarang. Berikut faktor pendukung keberhasilan dan penghambat 
kegiatan ekstrakurikuler paduan suara SMP Negeri 2 Semarang. Data mengenai faktor pendukung dan penghambat ekstrakurikuler paduan suara ini diperoleh dari hasil wawancara pada tanggal 10 Januari 2017 dengan bapak Teguh Waluyo S.Pd, MM selaku kepala SMP Negeri 2 Semarang dan bapak Sudaryono S.Pd selaku pelatih ekstrakurikuler paduan suara.

\subsubsection{Faktor Pendukung Ekstrakurikuler Paduan Suara SMP Negeri 2 Semarang}

Faktor pendukung kegiatan ekstrakurikuler Paduan Suara SMP Negeri 2 Semarang antara lain :

\subsubsection{Siswa}

Dalam paduan suara SMP Negeri 2 Semarang, peserta/ anggota paduan suara memiliki sikap kekeluargaan yang baik antar anggota paduan suara, hal ini dapat dilihat dari sikap kerjasama mereka untuk saling membantu dalam hal latihan mempelajari materi lagu secara bersama-sama. Kemudian pada minat siswa yakni minat yang sangat tinggi dalam kegiatan ekstrakurikuler paduan suara yang dapat dilihat dari banyaknya siswa yang mengikuti ekstrakurikuler paduan suara. Selain itu dibuktikan dengan banyaknya sebagian besar anggota paduan suara yang sangat rutin ketika mengikuti latihan setiap minggunya.

Minat mereka mengikuti paduan suara adalah karena mayoritas dari mereka sangat senang bernyanyi dan minat mereka juga semakin tinggi karena dorongan diri (motivasi) yang dimiliki setiap anggota untuk meraih prestasi di setiap perlombaan yang mereka ikuti sehingga mendapakan prestasi yang 
membanggakan baik di tingkat Provinsi maupun tingkat Nasional. Minat dan motivasi siswa ini merupakan salah satu pendorong keberhasilan dalam kegiatan pembelajaran ekstrakurikuler paduan suara di SMP Negeri 2 Semarang.

\subsubsection{Pelatih}

Pelatih sangat menentukan keberhasilan dalam kegiatan ekstrakurikuler paduan suara di SMP Negeri 2 Semarang ini. Bapak Sudaryono selaku guru seni musik dan pelatih ekstrakurikuler paduan suara memiliki sikap profesional yang tinggi dalam mengajar. Beliau adalah figur yang sangat disiplin dan tegas mengenai waktu latihan, selain itu beliau juga merupakan seorang mativator yang baik, dimana beliau mampu menumbuhkan sikap semangat dan percaya diri siswa anggota paduan suara. Sering kali pelatih memberikan motivasi kepada siswanya dengan cara menyemangati, memberikan pujian secara langsung agar anak mau terdorong untuk belajar lebih giat lagi. Sikap pelatih tersebut membuat siswa dalam pembelajaran mau mengikuti arahan dan instruksi dari pelatih.

Sikap pelatih dalam menghadapi masalah individu siswa mengenai kendala-kendala dalam pembelajaran dan berusaha untuk mengatasinya, sehingga terjalin kebersamaan, keakraban antara pelatih dengan siswa dalam kegiatan pembelajaran. Dalam pembelajaran yang berlangsung, beliau mampu menciptakan suasana belajar yang menyenangkan sehingga siswa tidak jenuh dan bosan. Halhal tersebut merupakan salah satu faktor pendorong keberhasilan ekstrakurikuler paduan suara di SMP Negeri 2 Semarang sehinggas membawa dampak positif terhadap kendala-kendala yang dihadapi siswa sehingga dapat terpecahkan. 


\subsubsection{Sekolah}

Faktor sekolah dari dulu terus mendukung adanya kegiatan ekstrakurikuler paduan suara dengan bukti program ini terus dilaksanakan tiap tahunnya. Dari pihak sekolah khususnya kepala sekolah sangat berperan serta dalam keberhasilan ekstrakurikuler paduan suara ini. Dukungan tersebut dapat dilihat dari sarana dan prasarana yang disediakan demi kelancarannya proses belajar mengajar paduan suara di SMP Negeri 2 Semarang. Sarana dan prasarana yang disediakan oleh pihak sekolah dapat membantu mempermudah jalannya proses belajar mengajar paduan suara.

Dari pihak sekolah SMP Negeri 2 Semarang memberikan fasilitas yang cukup, seperti ruangan untuk latihan rutin tiap minggunya yaitu ruangan musik yang nyaman yang dilengkapai dengan AC. Selain itu sekolah juga menyediakan alat musik keyboard yang digunakan pelatih sebagai media bantu dalam proses belajar mengajar paduan suara. Sekolah pun menyediakan air minum mineral untuk siswa pada proses pembelajaran berlangsung. Sekolah juga memfasilitasi mobil untuk sarana tranportasi ketika tim paduan suara mengikuti perlombaan. Selain itu yang tidak kalah pentingnya sekolah juga meyediakan biaya/ dana untuk kelancaran proses belajar mengajar paduan suara serta untuk tim paduan suara ketika mengadakan pentas atau pun mengikuti perlombaan. Dari itu semua dapat dilihat bahwa pihak sekolah sangat mendukung terselenggaranya kegitan ekstrakurikuler paduan suara di SMP Negeri 2 Semarang. 


\subsubsection{Faktor Penghambat Kegiatan Ekstrakurikuler Paduan Suara di SMP Negeri 2 Semarang.}

Selain dari faktor pendukung keberhasilan kegiatan ektrakurikuler paduan suara juga terdapat faktor kendala-kendala dalam kegiatan ekstrakurikuler paduan suara SMP Negeri 2 Semarang. Dari observasi dan wawancara yang diperoleh, faktor kendala ditimbulkan dari faktor siswa anggota paduan suara itu sendiri. Banyak siswa yang awalnya tidak bisa sama sekali membaca notasi angka. Mereka bisa benyanyi namun hanya hafalan saja karena buta terhadap nada. Banyak siswa yang tidak bisa membaca notasi sehingga menurunkan kepercayaan diri siswa dalam bernyanyi. Disini sangat dibutuhkan peran pelatih dalam membimbing siswa-siswi anggota paduan suara secara bertahap sehingga mereka dapat mengerti dan akhirnya bisa membaca notasi.

Selain itu yang menjadi kendala adalah faktor kedisiplinan siswa. Masih ada beberapa anggota paduan suara yang terlambat datang ketika latihan, lupa membawa partitur lagu. Disamping itu juga masih ada beberapa siswa yang terkadang tidak masuk dalam latihan sehingga hal ini membuat pelatih akan terus mengulang-ulang kembali materi untuk siswa yang tertinggal materi. Terkadang mereka lelah dan semangat mereka menurun dalam mengikuti kegiatan maka dari itu, disini peran pelatih sangat penting dengan memberikan motivasi dan pembelajaran yang menyenangkan terhadap siswa sehingga semangat mereka dalam mengikuti pembelajaran akan timbul kembali. 


\section{BAB V}

\section{PENUTUP}

\subsection{Simpulan}

Berdasarkan hasil penelitian dan pembahasan yang telah dipaparkan mengenai Pembelajaran Ekstrakurikuler Paduan Suara di SMP Negeri 2 Semarang disimpulkan bahwa proses pembelajaran ekstrakulikuler yang diterapkan oleh pelatih melalui tiga tahapan pembelajaran. Tahapan pembelajaran tersebut yaitu, (1) perencanaan meliputi persiapan materi lagu, mendata siswa, dan menyiapkan alat bantu pembelajaran, (2) pelaksanaan meliputi bentuk latihan antara lain pemanasan, sikap tubuh, pernapasan, artikulasi, intonasi, membaca notasi dan syair lagu, frasering, intrepretasi dan pembawaan lagu, keterpaduan, keseimbangan, (3) evaluasi meliputi tanya jawab dari kesulitan yang dihadapi siswa dalam menerima materi lagu, mengadakan perbaikan jika terjadi kesalahan sekaligus pelatih memberikan pengarahan dan motivasi, melakukan penilaian di setiap akhir semester yang kemudian akan dimasukan ke dalam nilai raport siswa.

Faktor-faktor yang mempengaruhi ekstrakurikuler paduan suara yaitu faktor pendukung dan penghambat. Faktor pendukung yaitu, (1) siswa yang memiliki sikap kekeluargaan dan kerjasama yang baik antar anggota, minat siswa dalam mengikuti ekstrakurikuler dilihat dari banyaknya siswa yang memilih mengikuti ekstrakurikuler paduan suara, dorongan diri siswa untuk meraih prestasi, (2) pelatih memiliki sikap profesional yang tinggi, sikap disiplin dan tegas, mampu menumbuhkan semangat dan percaya diri anggota paduan suara, 
mampu mendekatkan diri dengan siswa serta mampu menciptakan suasana belajar yang menyenangkan sehingga siswa tidak jenuh dan bosan. (3) sekolah yang menyediakan sarana dan prasarana. Sedangkan faktor penghambat ekstrakurikuler adalah siswa anggota paduan suara itu sendiri seperti minimnya kemampuan siswa dalam membaca notasi angka, kurangnya rasa percaya diri siswa dalam bernyanyi serta kurangnya kedisiplinan dalam mengikuti ekstrakurikuler paduan suara.

\subsection{Saran}

Dari hasill penelitian yang dilakukan, penulis menyarankan sebagai berikut:

(1) Siswa harus lebih percaya diri dalam bernyanyi paduan suara sehingga dapat memaksimalkan kemampuan dalam mengolah vokal.

(2) Siswa harus lebih disiplin dalam mengikuti pembelajaran ekstrakurikuler paduan suara.

(3) Dalam proses pembelajaran ekstrakurikuler paduan suara SMP Negeri 2 Semarang, hendaknya pelatih paduan suara terus menambah wawasan yang luas tentang musik terutama yang menyangkut dalam bidang olah vokal.

(4) Dalam proses pembelajaran lebih di tingkatkan lagi kreativitas, seperti materi lagu, ekspresi, penjiwaan dan juga gerakan dalam bernyanyi.

(5) SMP Negeri 2 Semarang diharapkan agar terus menjaga eksistensinya dalam mengembangkan ekstrakurikuler paduan suara.

(6) Bagi sekolah lain dapat menjadi referensi dalam pembelajaran paduan suara yang diterapkan oleh pelatih. 


\section{DAFTAR PUSTAKA}

Arikunto, Suharsimi. 2010. Prosedur Penelitian Suatu Pendekatan Praktik (edisi revisi). Jakarta: Rineka Cipta.

Aryanti, Anita. 2013. Upaya Meningkatkan Teknik Vokal Pada Paduan Suara Inovatif Dengan Menggunakan Metode Imitasi Dan Drill. Yogyakarta: Skripsi UNY.

Depdikbud. 1990. Petunjuk Pelaksanaan Proses Belajar Mengajar. Jakarta: Departemen Pendidikan dan Kebudayaan.

Depdikbud. 1994. Kurikulum Pendidikan Dasar (GBPP). Jakarta: Depdikbud.

Destiannisa, Ayugi. 2012. Implementasi Metode Pendekatan Kognitif dalam Pembelajaran Paduan Suara. Harmonia Journal Of Arts Research and EducationOnline,Vol.12,No.2.http://journal.unnes.ac.id/nju/index.php/harm onia/article/view/2524/2577. (Diakses pada tanggal 3 November 2016).

Dimyati dan Mudjiono. 2006. Belajar Dan Pembelajaran. Jakarta: PT Rineka Cipta.

Djamarah, Syaiful Bahri dan Zain, Aswan. 1996. Strategi Belajar Mengajar. Jakarta: PT Rineka Cipta.

Djamarah, Syaiful Bahri dan Zain, Aswan. 2002. Strategi Belajar Mengajar. Jakarta: PT Rineka Cipta

Djamarah, Syaiful. 2000. Guru dan Anak Didik ( Dalam Interaksi Edukatif). Jakarta: PT Rineka cipta.

Fais, Muchammad. 2011. Pembelajaran Ekstrakurikuler Rebana Terbang Zipin Di Madrasah Aliyah Negeri 01 Kabupaten Kudus. Semarang: Skripsi UNNES.

Fathurrohman Pupuh, dan Sutikno Sobry. 2007. Strategi Belajar Mengajar Melalui Penanaman Konsep Umum \& Konsep Islami. Bandung: PT Refika Aditama.

Hamalik, Oemar. 2008. Kurikulum Dan Pembelajaran. Bandung: PT Bumi Aksara.

Ichsan, Fuad.1991. Dasar-dasar Kependidikan. Jakarta: PT. Rineka Cipta.

Linggono, Budi. 2008. Seni Musik Nonklasik Untuk Sekolah Menengah Kejuruan. Jakarta: Direktorat Pembinaan Sekolah Menengah Kejuruan.

MDA, Cindy. 2013. Meningkatkan Kemampuan Bernyanyi dalam Kegiatan Ekstrakurikuler Paduan Suara Melalui Implementasi Metode Pendekatan Kognitif di SMA Negeri Banyumas. Semarang: Skripsi UNNES. 
Moleong, Lexy J. 2007. Metode Penelitian Kualitatif (edisi revisi). Bandung: PT REMAJA ROSDAKARYA.

Moleong, Lexy J. 2007. Metodologi Penelitian Kualitatif. Bandung: PT REMAJA ROSDAKARYA.

Moleong, Lexy. (2002). Metodologi Penelitian Kualitatif. Bandung: PT. remaja Rosdakarya.

Oktara, Bebbi. 2011. Jago Teknik Vokal. Jakarta: Gramedia.

Prastowo, Andi. 2016. Metode Penelitian Kualitatif Dalam Perspektif Rancangan Penelitian. Jakarta: AR-Ruzz Media

Rudy. 2008. Panduan Olah Vokal. Yogyakarta: MedPress.

Saputri, Rizki Dias. 2013. "Proses Pembelajaran Seni Musik Bagi Siswa Tunanetra". Harmonia: Journal af Arts and Education”. Juni 2013. Jilid 13, Nomor 1:38-39. Semarang: Universitas Negeri Semarang.

Sarwono, Jonathan . 2006. Metode Penelitian Kuantitatif \& Kualitatif. Yogyakarta: Graha Ilmu.

Simanungkalit, Nortir. 2008. Teknik Vokal Paduan Suara. Jakarta: Gramedia Pustaka Utama.

Sitompul, Binsar. 1986. Paduan Suara Dan Pemimpinnya. Jakarta: BPK Gunung Mulia.

Subagyo , Fasih. 2004. Terampil Bermain Musik 1-2. Tiga Serangkai: Solo

Subagyo, Joko. 2006. Metodologi Penelitian Dalam Teori Dan Praktek. Jakata: PT Rineka Cipta.

Sugiarto, dkk. 2001. Teknik Sampling. Jakarta: PT Gramedia Pustaka Utama, anggota IKAPI.

Suharto. (2009, Maret). Pembinaan Paduan Suara Di Perguruan Tinggi. https://sriambarwangi.wordpress.com/2009/03/27/pembinaan-paduansuara-di-perguruan-tinggi/. (Diakses pada tanggal 21 Agustus 2016).

Suharto. (1999). Peran Ganda Dirigen sebagai Tenaga Profesional dalam Paduan Suara. Lingua Artistika, 13 (2), 134.

Suharto. (2007). Pengembangan Materi Dan Kegiatan Pembelajarannya Dalam Kurikulum Tingkat Satuan Pendidikan Bidang Seni Musik. Harmonia Journal Of Arts Research and Education, 8 (3)

Suharto. 2015. Strategi Belajar Mengajar. Semarang: Fakultas Bahasa dan Seni UNNES.

Sukmadinata, Nana Syaodih dan Ibrahim. 2003. Perencanaan Pengajaran. Jakarta: PT. Rineka Cipta. 
Sukmadinata, Nana Syaodih. 2009. Metode Penelitian Pendidikan. Bandung: PT REMAJA ROSDAKARYA.

Sukrisno, Cahyo. 2015. Pembelajaran Vokal dengan Metode Solfegio Pada Paduan Suara Gracia Gita Suara di GKJ Cilacap Utara Kabupaten Cilacap. Jurnal Seni Musik Online, Vol. 4, No. 1. http://journal.unnes.ac.id/sju/index.php/jsm. (Diakses pada tanggal 3 November 2016).

Sulasmono, Putut. 2013. Peningkatan Kemampuan Vokal Melalui Metode Solfegio. Harmonia Journal Of Arts Research and Education Online, Vol. 13,No.1. $\quad$ http://journal.unnes.ac.id/nju/index.php/harmonia/articlel. (Diakses pada tanggal 3 November 2016).

Sumaryanto, F Totok. 2005. Efektifitas Penggunaan Metode Solfegio Untuk Pembelajaran Keterampilan Bermain Musik Di Sekolah Dasar. Harmonia Journal Of Arts Research and Education Online, Vol. 6, No. 2. http://journal.unnes.ac.id/nju/index.php/harmonia/articlel. (Diakses pada tanggal 3 November 2016).

Susetyo, Bagus. 2005. Kondakting. Univesitas Negeri Semarang . Semarang: Fakultas Bahasa dan Seni.

Sutirman. 2013. Media Dan Model-Model Pembelajaran Inovatif. Yogyakarta: Graha Ilmu.

Tezar, Yudi. 2008. Pembelajaran Ekstrakurikuler Ansambel Gesek Di SMA Negeri 03 Semarang. Semarang: Skripsi UNNES.

Tim Pusat Musik Liturgi. 2013. Menjadi Dirigen III. Yogyakarta: PML

Tim Pusat Musik Liturgi. 2016. Menjadi Dirigen II. Yogyakarta: PML

Tri Ani, Catharina dan Rifai, Achamd. 2012. Psikologi Pendidikan. Semarang: UPT UNNES PRESS.

Uno, B Hanzah. 2006. Perencanaan Pembelajaran. Jakarta: PT Bumi Aksara.

Usman, Husaini dan Setiady, Purnomo. 2014. Metodologi Penelitian Sosial. Jakarta: PT Bumi Aksara.

Utomo, Udi dkk. 2014. Materi Ajar Musik Pendidikan. Semarang: UNNES.

Utomo, Udi. 2013. Analisis Kebutuhan Guru Seni Musik Dalam Konteks Pelaksanaan Pembelajaran Berbasi Action Learning Di Sekolah. Harmonia Journal Of Arts Research and Education Online, Vol. 13, No. 2. http://journal.unnes.ac.id/nju/index.php/harmonia/articlel. (Diakses pada tanggal 3 November 2016). 


\section{LAMPIRAN}




\section{LAMPIRAN I}

\section{INSTRUMEN PENELITIAN}




\section{PEDOMAN OBSERVASI}

1. Proses kegiatan pembelajaran yang berlangsung, meliputi jalannya kegiatan seperti, teknik- teknik yang diajarkan pelatih ekstrakurikuler paduan suara.

2. Metode yang digunakan pelatih dalam pembelajaran ekstrakurikuler paduan suara.

3. Interaksi pelatih dengan peserta paduan suara.

4. Sikap pelatih dalam megajar

5. Sikap siswa anggota paduan suara dalam mengikuti pembelajaran, 


\section{PEDOMAN WAWANCARA}

Peneliti mengajukan pertanyaan kepada informan berdasarkan pembatasan materi wawancara, antara lain :

\section{Kepala sekolah}

Yaitu megenai sejarah SMP Negeri 2 Semarang, kapan ekstrakurikuler paduan suara diselenggarakan, tujuan diselenggarakan ektrakurikuler paduan suara, prestasi yang telah diraih oleh ektrakurikuler paduan suara, peran kepala sekolah terhadap ektrakurikuler paduan suara, penilaian kepala sekolah terhadap pelatih paduan suara.

1.1 Sejak kapan kegiatan ekstrakurikuler paduan suara diselenggarakan?

1.2 Apa tujuan diselenggarakannya ekstrakurikuler paduan suara?

1.3 Prestasi apa saja yang telah diraih oleh ekstrakurikuler paduan suara SMP Negeri 2 Semarang?

1.4 Apa peran bapak sebagai kepala sekolah terhadap ekstrakurikuler paduan suara?

1.5 Bagaimana penilaian bapak terhadap kinerja pelatih paduan suara? 


\section{Pelatih ekstrakuler paduan suara}

Yaitu mengenai proses pembelajaran yang meliputi penentuan materi pembelajaran, teknik dan metode yang terapkan dalam pembelajaran, hambatan pelaksanaan kegiatan, dan faktor-faktor penghambat dan pendorong yang mempengaruhi proses kegiatan pembelajaran ekstrakurikuler paduan suara, tanggapan siswa dalam mengikuti pembelajaran.

2.1 Pada hari apa jadwal dilaksanakannya pembelajaran ekstrakurikuler paduan suara?

2.2 Bagaiamana proses pembelajaran ekstrakurikuler paduan suara yang bapak terapkan?

2.3 Bagaimana sikap bapak dalam menghadapi siswa selama latihan?

2.4 Seperti apa materi yang bapak sampailan kepada siswa?

2.5 Metode apa yang bapak terapkan dalam pembelajaran?

2.6 Apa faktor-faktor penghambat dan pendukung yang mempengaruhi proses kegiatan pembelajaran ekstrakurikuler paduan suara?

2.7 Menurut bapak bagaimana tanggapan siswa dalam mengikuti pembelajaran? 


\section{Siswa Ekstrakurikuler Paduan Suara.}

Yaitu mengenai pendapat siswa tentang kegiatan ektrakurikuler paduan suara, minat siswa dalam mengikuti ekstrakurikuler paduan suara, harapkan siswa dalam mengikuti ekstrakurikuler paduan suara, apa yang membuat siswa tertarik atau menyukai kegiatan ekstrakurikuler paduan suara, serta hambatan yang dialami siswa anggota ekstrakurikuler paduan suara dalam mengikuti proses pembelajaran, dan cara pelatih dalam menyampaikan materi.

3.1 Bagaimana pendapat anda tentang kegiatan ekstrakurikuler paduan suara?

3.2 Apakah anda rutin mengikuti kegiatan ekstrakurikuler paduan suara?

3.3 Apa yang membuat anda berminat mengikuti ekstrakurikuler paduan suara?

3.4 Apa harapkan anda setelah tergabung menjadi anggota ekstrakurikuler paduan suara?

3.5 Bagaimana perasaan anda jika terpilih menjadi anggota tim perwakilan sekolah dalam mengikuti berbagai perlombaan dan pementasan di acaraacara tertentu?

3.6 Bagaimana menurut anda tentang cara pelatih dalam menyampaikan materi? 


\section{PEDOMAN DOKUMENTASI}

1. Gambar gedung SMP Negeri 2 Semarang.

2. Gambar ruangan ekstrakurikuler paduan suara.

3. Gambar sarana dan prasarana yang digunakan dalam pembelajaran ekstrakurikuler paduan suara, gambar piala-piala kejuaran lomba paduan suara SMP Negeri 2 Semarang.

4. Arsip atau file gambar siswa saat mengikuti pementasan.

5. Foto pada saat pembelajaran ekstrakurikuler paduan suara.

6. Data siswa yang mengikuti ekstrakurikuler paduan suara. 


\section{LAMPIRAN II \\ JAWABAN INSTRUMEN PENELITIAN}




\section{HASIL OBSERVASI}

\begin{tabular}{|c|c|c|}
\hline No & Kegiatan & Keterangan \\
\hline 1 & $\begin{array}{l}\text { Proses kegiatan } \\
\text { pembelajaran }\end{array}$ & $\begin{array}{l}\text { Proses pembelajaran ekstrakurikuler yang } \\
\text { diterapkan oleh pelatih melalui tahap-tahap } \\
\text { pembelajaran yaitu, (1) perencanaan yang meliputi } \\
\text { persiapan materi lagu, mendata siswa, dan } \\
\text { menyiapkan alat bantu pembelajaran, (2) } \\
\text { pelaksanaan meliputi bentuk latihan antara lain } \\
\text { pemanasan, sikap tubuh, pernapasan, artikulasi, } \\
\text { intonasi, membaca notasi dan syair lagu, frasering, } \\
\text { intrepretasi dan pembawaan lagu, keterpaduan, } \\
\text { keseimbangan, (3) evaluasi meliputi tanya jawab } \\
\text { dari kesulitan yang dihadapi siswa dalam menerima } \\
\text { materi lagu, mengadakan perbaikan jika terjadi } \\
\text { kesalahan sekaligus pelatih memberikan } \\
\text { pengarahan dan motivasi. }\end{array}$ \\
\hline 2 & $\begin{array}{l}\text { Metode yang di- } \\
\text { gunakan pelatih } \\
\text { dalam pem- } \\
\text { belajaran ekstra- } \\
\text { kurikuler paduan } \\
\text { suara }\end{array}$ & $\begin{array}{l}\text { Metode yang diterapkan oleh pelatih yaitu ceramah, } \\
\text { demonstrasi, latihan/ drill, Tanya-jawab/ diskusi, } \\
\text { tutor sebaya. }\end{array}$ \\
\hline
\end{tabular}




\begin{tabular}{|c|c|c|}
\hline 3 & $\begin{array}{l}\text { Interaksi pelatih } \\
\text { dengan peserta } \\
\text { paduan suara. }\end{array}$ & 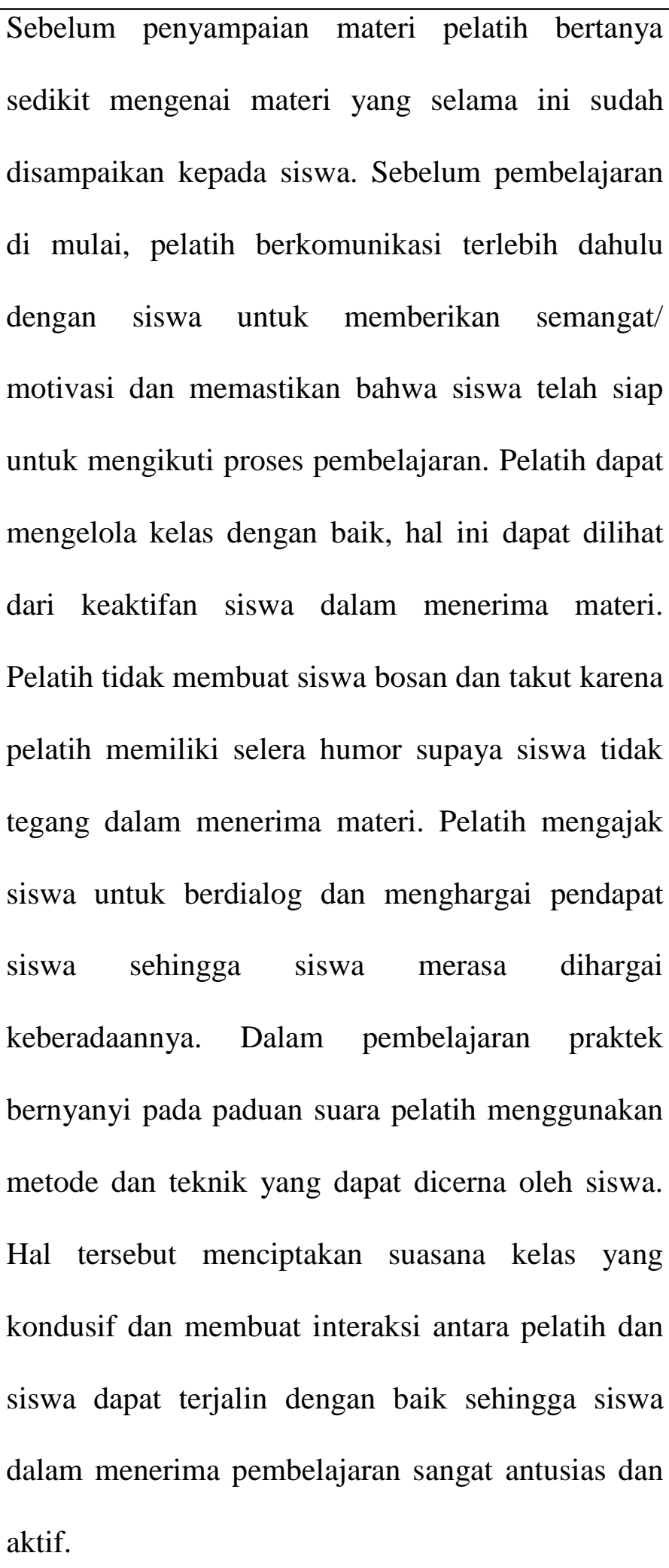 \\
\hline 4 & Sikap pelatih dalam & kan sosok yang ramah dan akra \\
\hline
\end{tabular}




\begin{tabular}{|l|l|l|}
\hline megajar & terhadap peserta didik/ anggota paduan suara \\
namun tetap tegas dalam menyampaikan materi. \\
Beliau juga merupakan sosok yang disiplin, hal itu \\
dilihat ketika beliau menerapkan tata tertib dalam \\
mengikuti ekstrakurikuler paduan suara. Dan selalu \\
mengadakan evaluasi di akhir pembelajaran dengan \\
menanyakan kesulitan siswa dalam menerima \\
anggota paduan \\
suara dalam me- \\
ngikuti \\
belajaran
\end{tabular}




\section{HASIL WAWANCARA}

\section{Kepala Sekolah}

1.1 Jawab:

Paduan Suara SMP Negeri 2 Semarang di beri nama Espero Choir, berdiri pada tanggal 13 Mei 2002.

\subsection{Jawab:}

Dalam rangka pengembangan kemampuan dan menggali potensi siswa untuk mengolah rasa dalam suara maka SMP Negeri 2 Semarang merasa perlu mengadakan kegiatan ekstrakurikuler salah satu cabang seni yaitu Paduan Suara. Paduan suara SMP Negeri 2 Semarang merupakan salah satu ekstrakulikuler yang baik untuk diikuti oleh siswa-siswi SMP Negeri 2 Semarang yang memiliki bakat dan minat dalam mengolah vokal yang dimiliki karena paduan suara merupakan wadah untuk melatih vokal dan pengolahan suara. Ektrakurikuler paduan suara juga melatih kekompakan antar sesama agar suara paduan suara menjadi sama dan sewarna. Tujuan adanya ekstrakurikuler paduan suara adalah untuk membentuk sikap dan mental siswa agar dapat diterapkan dalam kehidupan sehari-hari. Karena didalam ekstrakurikuler paduan suara selain siswa belajar berolah vokal didalam pembelajaran juga menanamkan nilai-nilai seperti belajar bekerjasama, saling menghargai, percaya diri, serta disiplin.

\subsection{Jawab:}


Banyak sekali prestasi yang telah telah diraih oleh paduan suara SMP Negeri 2 Semaranmg. Salah satunya Medali emas Nasional Choir Festival USM 2016. Prestasi yang lainnya bisa dilihat di dokumentasi ekstrakurikular paduan suara saja.

\subsection{Jawab:}

Saya sangat mendukung dengan adanya kegiatan ekstrakurikuler paduan suara ini untuk tetap terus berjalan. Selain itu dukungan juga malalui sarana dan prasarana dari pihak sekolah untuk membantu siswa mengembangkan keterampilannya. Saya pun selalu mendukung dan men suport setiap kegiatan paduan suara SMP Negeri 2 Semarang, seperti lomba-lomba.

\subsection{Jawab:}

proses pembelajaran ekstrakurikuler paduan suara SMP Negeri 2 Semarang di bimbing oleh 1 orang pengajar yaitu guru musik sekolah SMP Negeri 2 Semarang, bernama bapak Sudaryono S. Pd. Beliau adalah lulusan Pendidikan Seni Musik dari Universitas Negeri Semarang. Beliau mengajar ekstrakurikuler paduan suara di SMP Negeri 2 Semarang sejak tahun 2003. Sebagai pelatih ekstrakurikuler paduan suara bapak Sudaryono S. Pd merupakan guru yang tanggung jawab dan disiplin dalam dalam membimbing siswa dan memiliki andil yang besar terhadap kemajuan serta prestasi ektrakurikuler paduan suara di sekolah tersebut. 


\section{Pelatih Esktrakurikuler Paduan Suara}

\subsection{Jawab:}

Jadwal pembelajaran latihan rutin ekstrakurikuler paduan suara di SMP Negeri 2 Semarang dilaksanakan pada hari senin setelah jam pulang sekolah, yaitu jam 14.45 s/d 16.15. Waktu pelaksanaan dilakukan satu kali pertemuan dalam satu minggu.

\subsection{Jawab:}

Proses pembelajaran melalui tiga tahapan yaitu, (1) perencanaan meliputi persiapan materi lagu, mendata siswa, dan menyiapkan alat bantu pembelajaran, (2) pelaksanaan meliputi bentuk latihan olah vokal (3) evaluasi meliputi tanya jawab dari kesulitan yang dihadapi siswa dalam menerima materi lagu, mengadakan perbaikan jika terjadi kesalahan sekaligus memberikan pengarahan dan motivasi, melakukan penilaian di setiap akhir semester yang kemudian akan dimasukan ke dalam nilai raport siswa.

\subsection{Jawab:}

Setiap siswa itu berbeda-beda mbak karakternya, ya saya melakukan pendekatan saja kepada siswa supaya dalam proses belajar mengajar berjalan dengan santai agar anak tidak merasa takut dalam belajar. Saya selalu mengingatkan tentang hal kedispinan seperti waktu latihan untuk ketertiban agar proses berlajar mengajar berjalan dengan baik selain itu juga agar anak belajar bertanggung jawab terutama pada dirinya sendiri. Saya sering memberikan motivasi kepada siswa anggota paduan suara dengan cara 
menyemangati, memberikan pujian secara langsung agar anak mau terdorong untuk belajar lebih giat lagi.

\subsection{Jawab:}

Banyak, seperti materi bentuk latihan vokal paduan suara yaitu latihanpemanasan, sikap tubuh, pernapasan, artikulasi, intonasi, membaca notasi dan syair lagu, frasering, intrepretasi dan pembawaan lagu, keterpaduan, keseimbangan. Materi lagu yang saya berikan seperti lagu-lagu nasional, perjuangan, mars, lagu daerah dan lagu umum juga.

\subsection{Jawab:}

Metode tutor sebaya, latihan/ drill, demonstrasi, ceramah, diskusi/tanya jawab.

\subsection{Jawab:}

Faktor pendukungnya siswa memiliki sikap kekeluargaan dan kerjasama yang baik antar anggota, minat siswa dalam mengikuti ekstrakurikuler dilihat dari banyaknya siswa yang memilih mengikuti ekstrakurikuler paduan suara, dorongan diri siswa untuk meraih prestasi. Sekolah pun juga sangat mendukung terlaksananya kegiatan ekstrakurikuler ini seperti menyediakan sarana dan prasarana. Sedangkan faktor penghambatnya adalah siswa anggota paduan suara itu sendiri seperti minimnya kemampuan siswa dalam membaca notasi angka banyak sekali siswa yang buta terhadap nada. Jadi saya harus mengajarkan not angka dulu kepada siswa supaya tidak fals dalam bernyanyi. karena menurut saya membaca notasi itu snagtr penting. Selain itu juga, masih ada siswa yang kadang sering lupa membawa partitur lagu pada saat 
pembelajran berlangsung. Dan masih ada sebagian siswa yang bolos tidak masuk. Jadi saya harus mengulang-ulang materinya.

\subsection{Jawab:}

Siswa sangat antusias dengan adanya ekstrakurikuler paduan suara ini. Terbukti dari banyknya siswa yang mengikuti esktrakurikuler ini. Jumlah nya sangat banyak dan saya pun tidak melakukan seleksi kepada siswa karena tidak mungkin saya menolak mereka yang ingin belajar. Mereka ingin mengikuti ekstra padua suara ini berarti kan ada motivasi dari diri mereka untuk belajar bernyanyi dalam paduan suara. Tapi ada juga yang memang hanya iseng coba-coba atau bahkan tidak berniat, namun mereka akan keluar dengan sendirinya dari kegiatan eksterakurikuler ini. Memang untuk masuk ekstrakurikuler paduan suara ini tidak dilakukan seleksi namun pada saat perwakilan dalam mengikuti lomba saya melakukan seleksi pada siswa yang sudah tergabung dalam eksstrakurimkuler paduan suara SMP Negeri 2 Semarang. 


\section{Siswa 1}

Nama : Keysha Diva Azzahra

Kelas : VIII A

3.1 Jawab:

Ekstrakurikuler paduan suara ini sangat menyenangkan kak, karena saya bisa berlatih bernyanyi bersama teman-teman, saya memiliki teman-teman yang banyak melalui ekstrakurikuler ini.

\subsection{Jawab:}

Ya, saya rutin mengikuti esktrakurikuler paduan suara ini kak.

\subsection{Jawab:}

Yang membuat saya berminat mengikuti ekstrakurikuler ini untuk menambah pengalaman di bidang olah vokal dan sebagai wadah saya untuk berlatih vokal karena saya nanti ingin kuliah di Institut Seni Indonesia jurusan vokal kak.

\subsection{Jawab:}

Saya ingin lebih baik lagi dalam bernyanyi dan saya ingin ikut lomba paduan suara yang mewakili sekolah.

\subsection{Jawab:}

Perasaan saya pastinya senang kak, karena dengan mengikuti lomba paduan suara yang mewakili sekolah menjadi suatu kebanggaan tersendiri bagi saya dan memotivasi untuk belajar lebih giat dalam bernyanyi secara paduan suara melalui ekstrakurikuler paduan suara ini.

\subsection{Jawab:}

Pelatih orangnya baik, santai tapi juga tegas dalam menyampaikan materi. 


\section{Siswa II}

Nama : Ayesha Adilla $\mathrm{S}$

Kelas : VIII B

3.1 Jawab:

Menurut saya ekstrakurikuler paduan suara ini seru, teman-temannya banyak, gurunya juga baik.

\subsection{Jawab:}

Ya, saya rutin kak tapi sering juga sih bolos kalau ada kepentingan mendadak diluar sekolah

\subsection{Jawab:}

Saya berminat mengikuti ekstrakurikuler ini supaya saya bisa bernyanyi kak.

Setelah mengikuti ekstra ini sedikit-dikit saya bisa bernyanyi dan membaca not angka.

3.4 Jawab:

Harapannya ingin ikut lomba yang mewakili sekolah kak.

\subsection{Jawab:}

Senang kak. Pasti orang tua saya juga ikut senang kalau saya terpilih menjadi tim yang mewakili sekolah.

3.6 Jawab:

Beliau orangnya suka bercanda, lucu, tapi tegas dalam mengajar. 


\section{HASIL DOKUMENTASI}
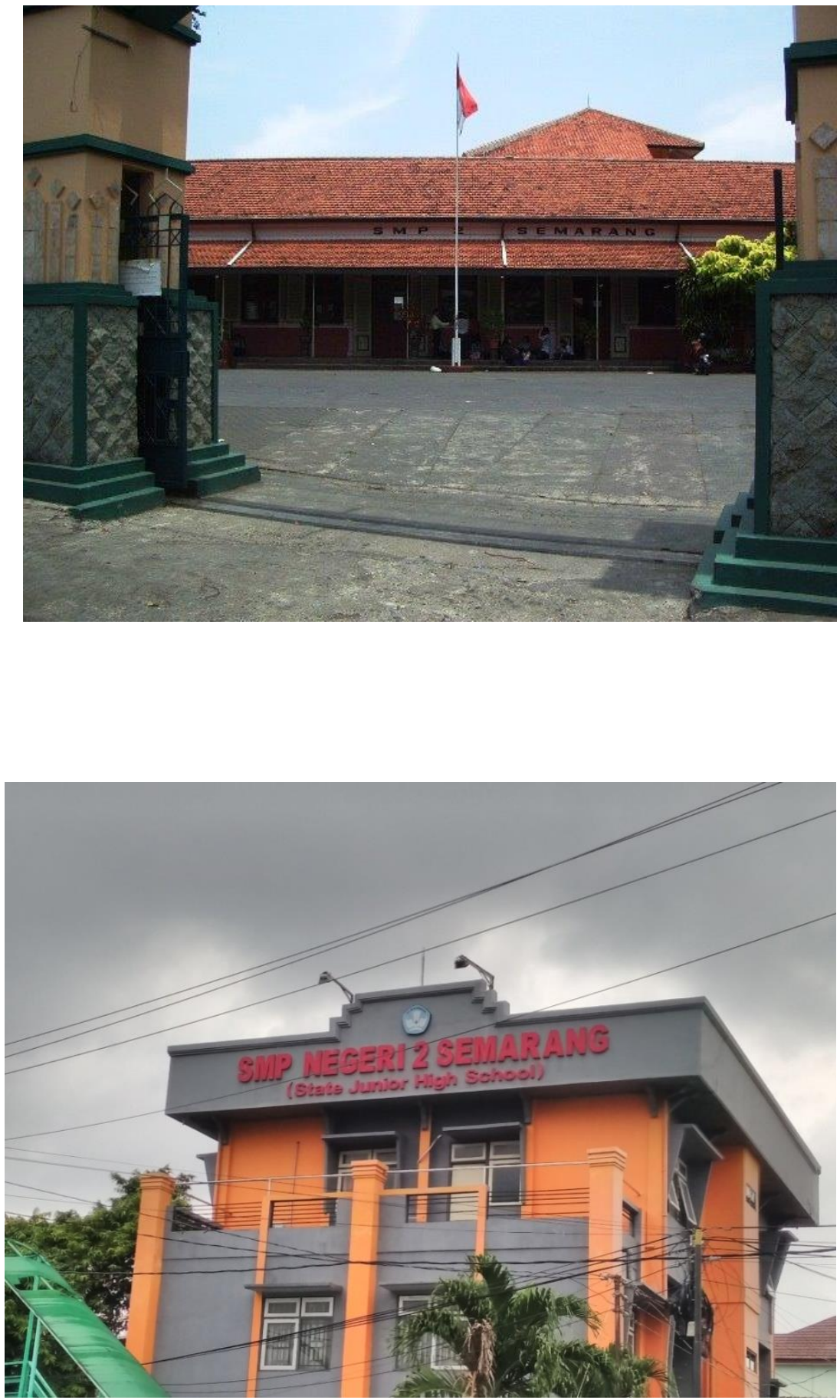

Gedung SMP Negeri 2 Semarang 

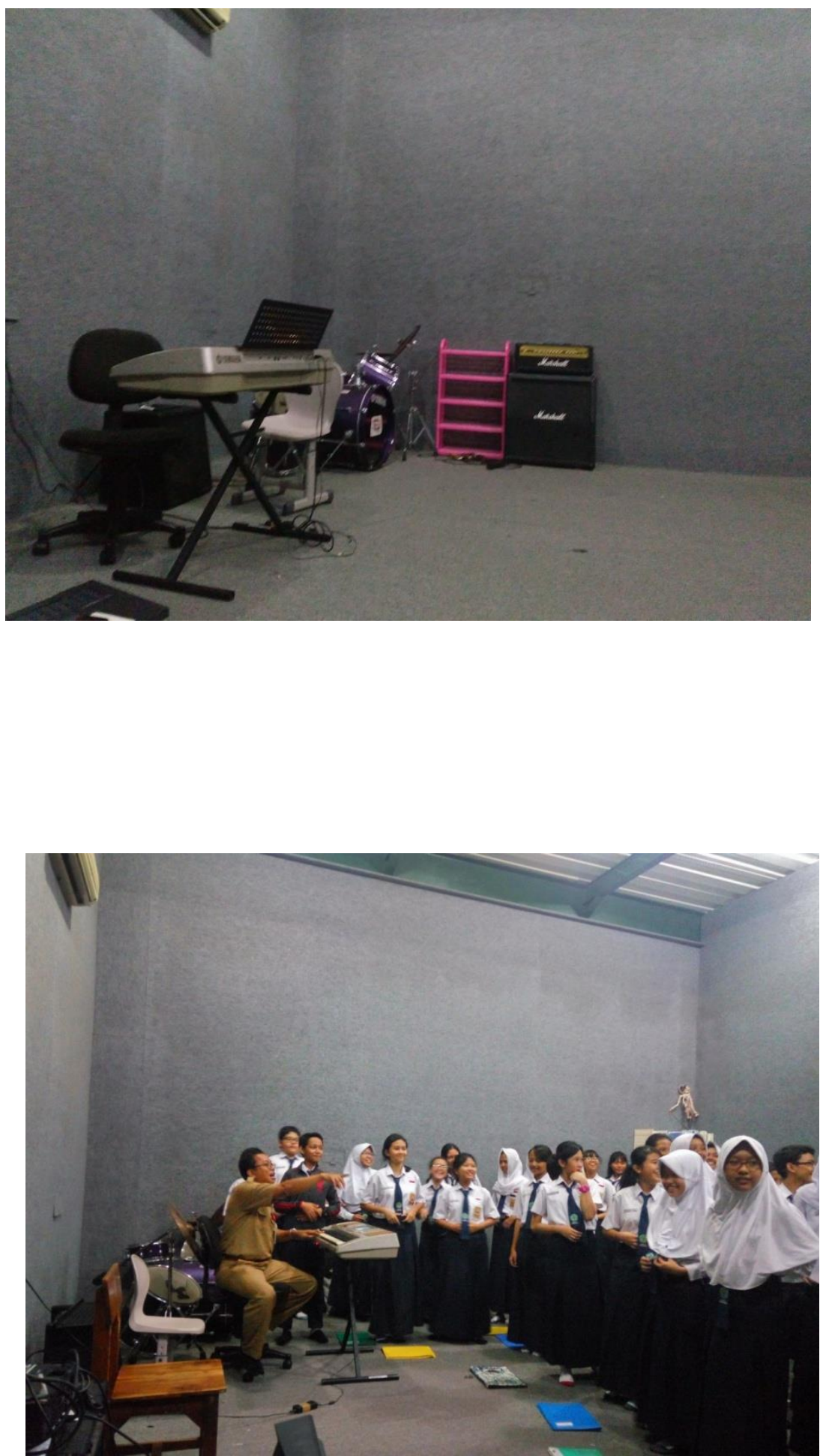

Ruangan Ekstrakurikuler dan sarana pembelajaran 

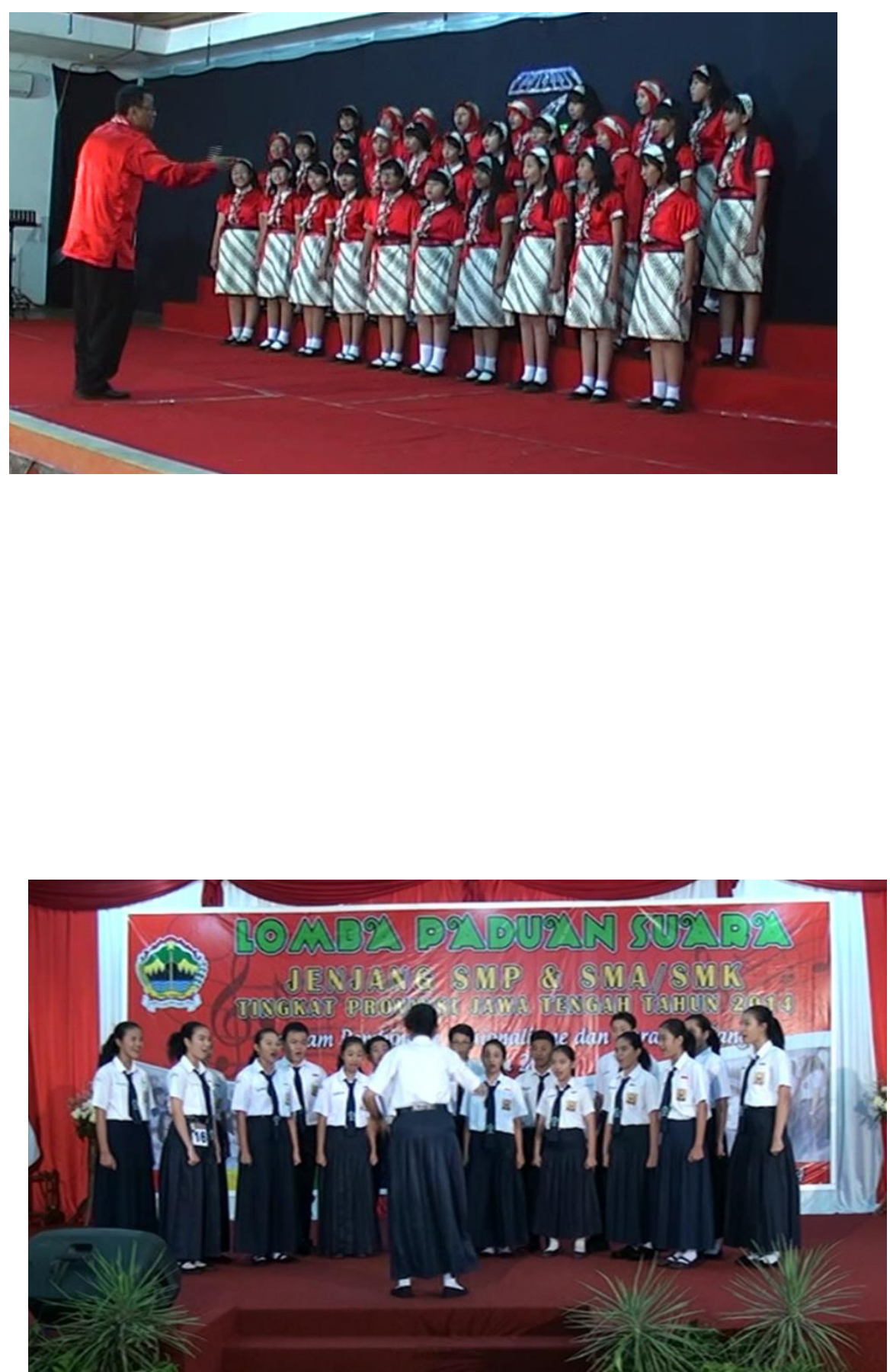

Siswa SMP Negeri 2 Semarang mengikuti pementasan 

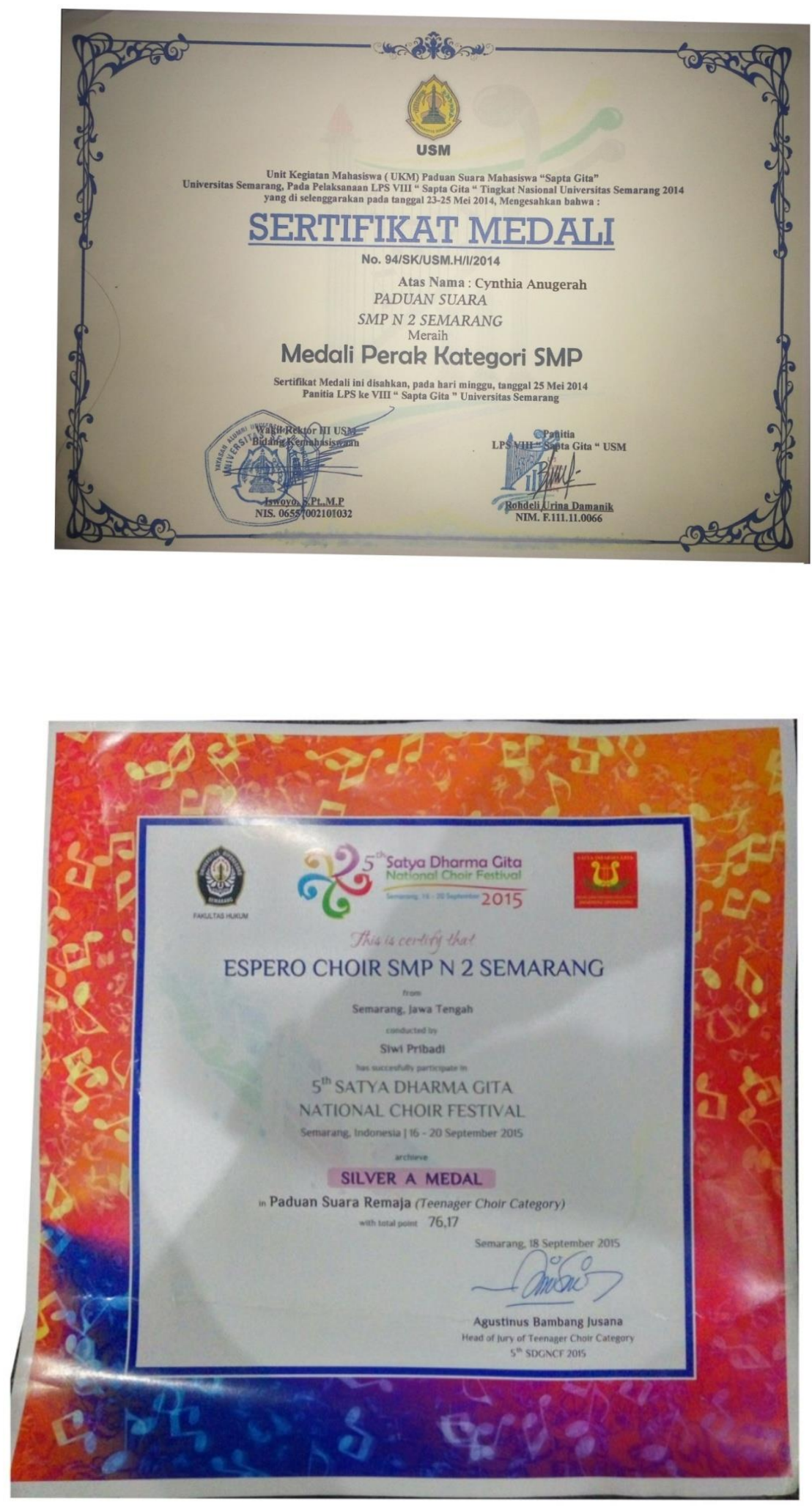

Sertifikat kejuaraan lomba paduan suara 

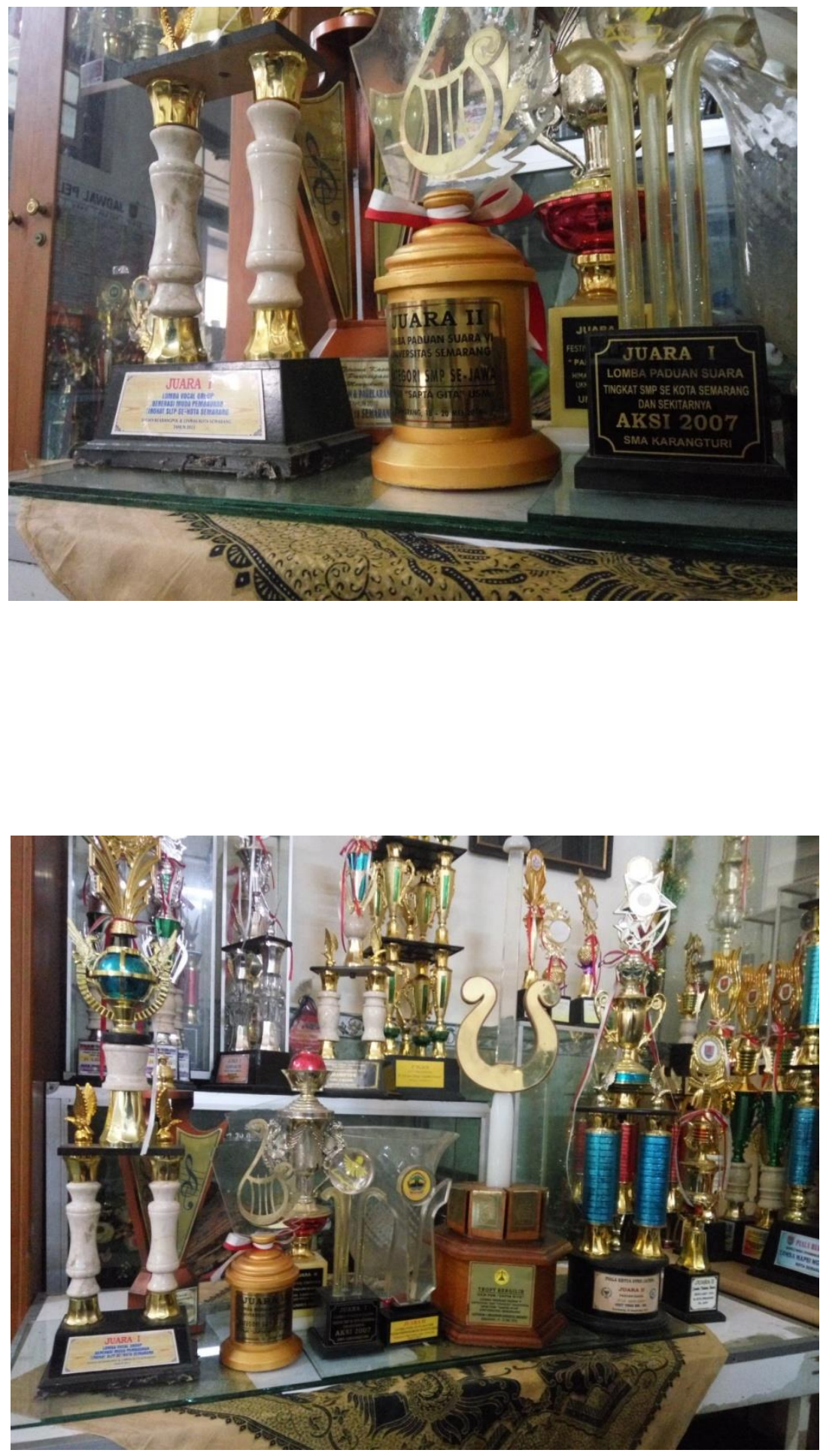

Piala-piala kejuaraan lomba paduan suara 


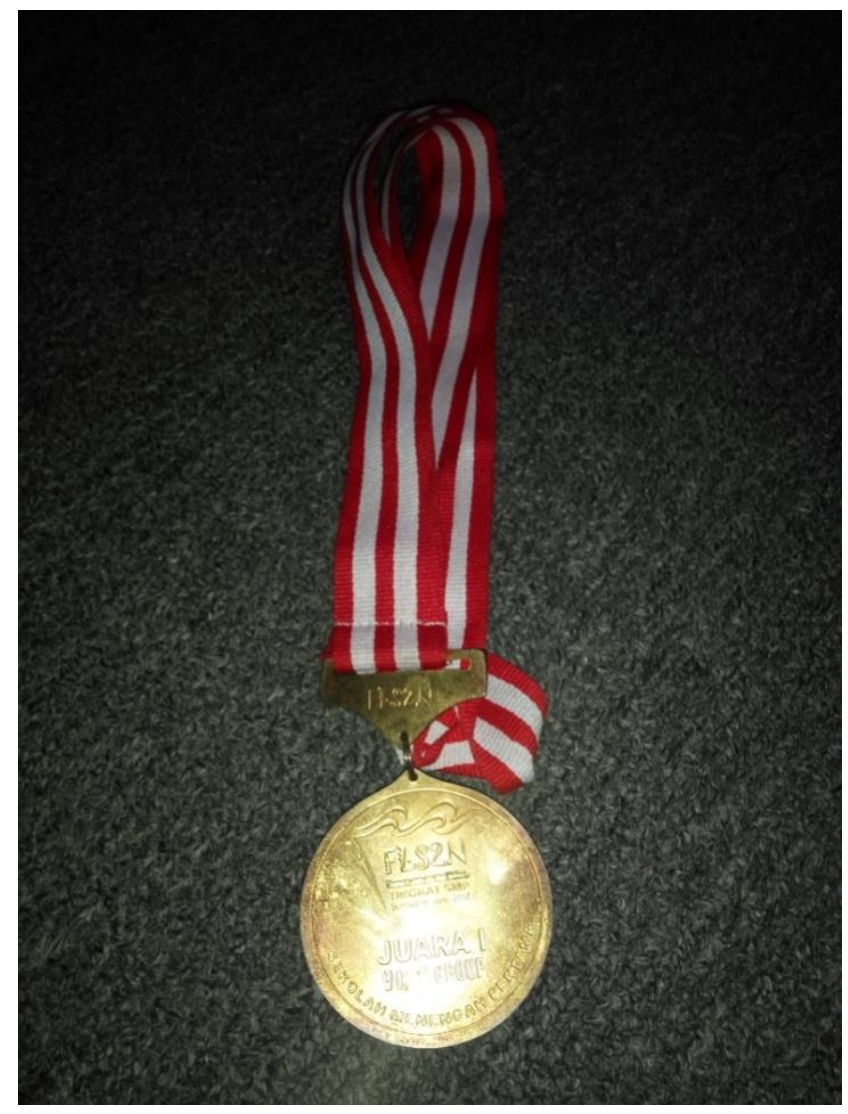

Medali emas kejuaraan lomba paduan suara 


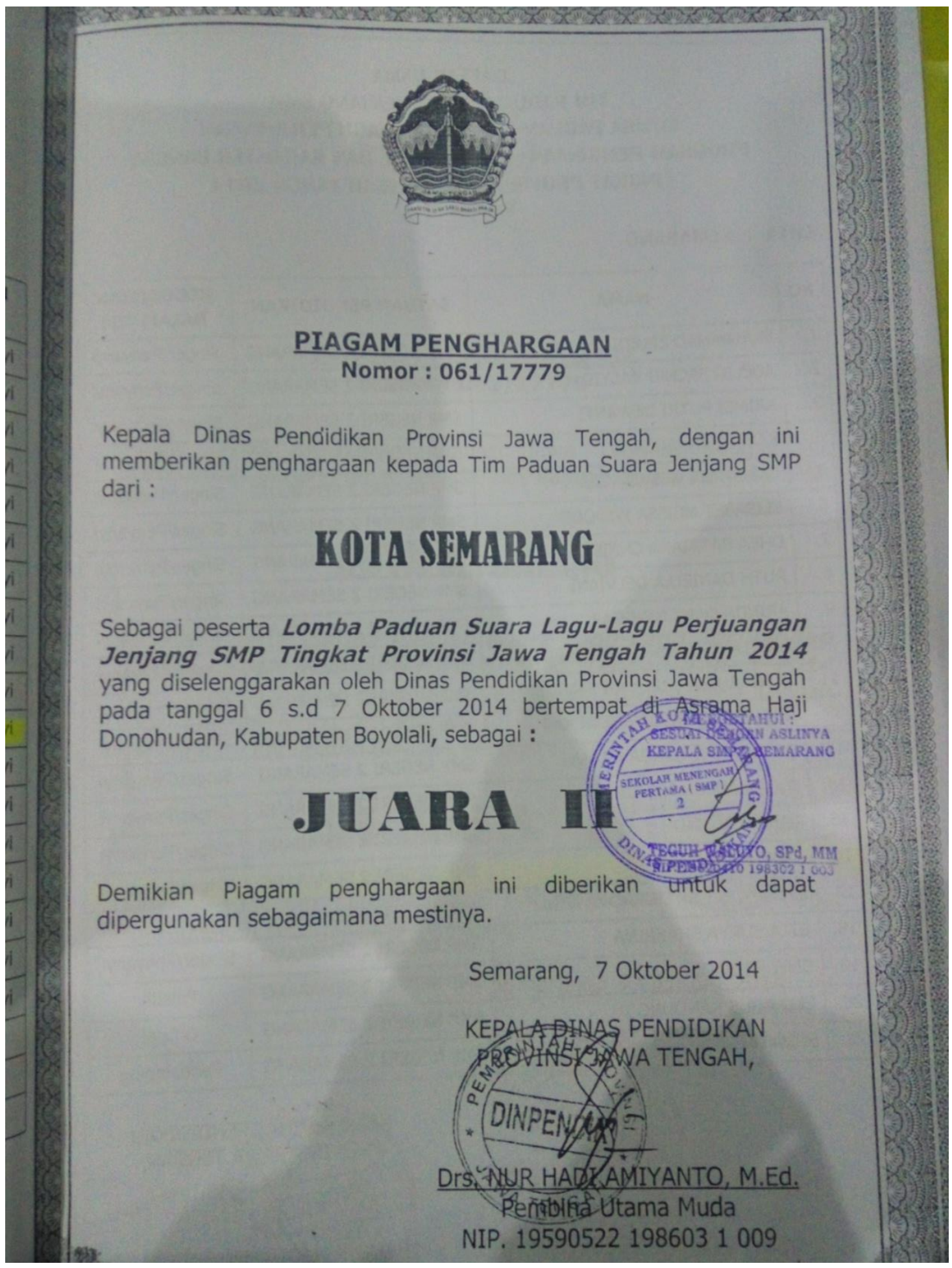


Piagam kejuaraan lomba paduan suara
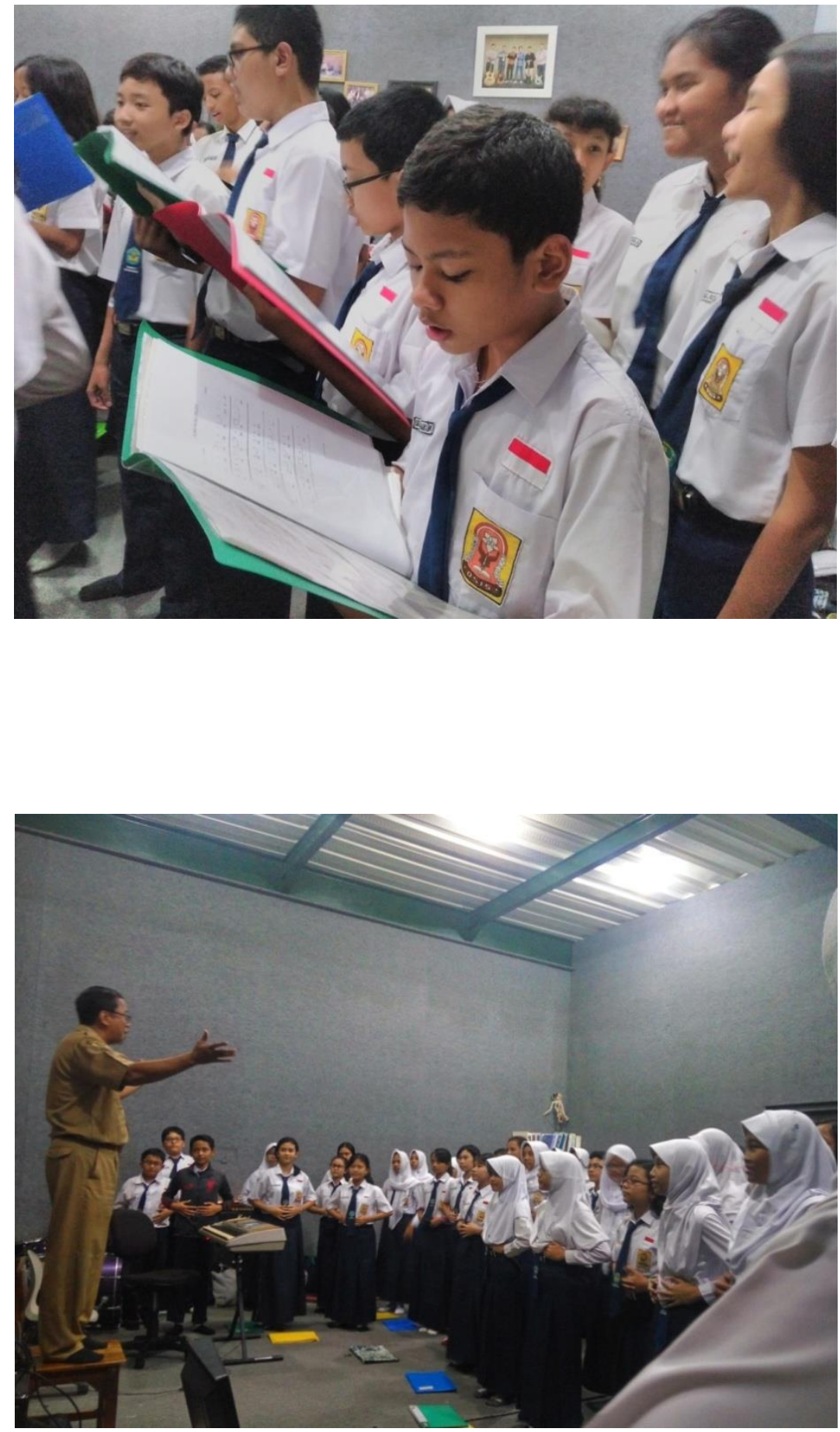

Pembelajaran ekstrakurikuler paduan suara 
aryawan

\begin{tabular}{|c|l|c|l|}
\hline No & \multicolumn{1}{|c|}{ Nama } & Jabatan & \multicolumn{1}{|c|}{ Alamat } \\
\hline 1. & Wuryanto & TU & Jl. Megaraya I/206 Ngaliyan Smg \\
\hline 2. & Nur Wadirahayu & TU & Jl. Sidodrajat VI/5 Smg \\
\hline 3. & Ernawati, A.Md. & TU & $\begin{array}{l}\text { Jl. Cempedak Utara No. 23 B RT 03/I } \\
\text { Lamper Lor Smg Slt }\end{array}$ \\
\hline 4. & Supar & TU & Jl. Singa Timur II RT 02 RW VII Smg \\
\hline 5. & $\begin{array}{l}\text { Ngasti Rahayu } \\
\text { Istiana }\end{array}$ & TU & Jl. Kelinci I/221 \\
\hline 6. & Huzaemah, S.Pd & TU & Jl Mirah Delima Raya 4 RT 02 RW 03 \\
\hline 7. & Puji Astuti & TU & Jl. Tanah Putih 85 \\
\hline 8. & Wagino & TU & Jl. Pucang Santosa Brt II/11 \\
\hline 9. & Kartoyo & TU & Jl. Kebonrejo Brt IV/9 \\
\hline 10. & Sumiyem & TU & Jl. Wonodri Joho I RT 5/03 \\
\hline 11. & Rohmad Saefudin & $\begin{array}{l}\text { Jl. Jatikusuman 6 RT 04 RW 05 Kel. } \\
\text { Mranggen Kec Mranggen Kab. Demak }\end{array}$ \\
\hline 12. & $\begin{array}{l}\text { Akbar Kadarusman, } \\
\text { S.Kom. }\end{array}$ & TU & Jl. Bulu Stalan III/a No. 407 E Smg \\
\hline 13. & Ngatmin & TU & Jl. Pucang Santosa Barat II/8 \\
\hline
\end{tabular}

\section{Data Jumlah Siswa}

\begin{tabular}{|c|c|}
\hline Kelas & Jumlah Siswa \\
\hline VII & 286 \\
\hline VIII & 288 \\
\hline XI & 240 \\
\hline Jumlah keseluruhan & 814 \\
\hline
\end{tabular}


Daftar Anggota Paduan Suara SMP Negeri 2 Semarang Semester Gasal

Tahun Pelajaran 2016/2017.

\begin{tabular}{|c|c|l|c|c|}
\hline NO & NIS & & L/P & KLS \\
& & & & \\
\hline 1 & 19957 & Berliana Nabila A.Z & $\mathrm{P}$ & $7 \mathrm{~A}$ \\
2 & 20035 & Kayla Aurelia Z & $\mathrm{P}$ & $7 \mathrm{~A}$ \\
3 & 20116 & Raden Roro Pinky R & $\mathrm{P}$ & $7 \mathrm{~A}$ \\
4 & 20175 & Vondra Amabel A & $\mathrm{P}$ & $7 \mathrm{~A}$ \\
5 & 20182 & Zahra Putri Aulia & $\mathrm{P}$ & $7 \mathrm{~A}$ \\
6 & 20184 & Zidan Revano Putra & $\mathrm{L}$ & $7 \mathrm{~A}$ \\
7 & 19914 & Alysia Vashti Kama & $\mathrm{P}$ & $7 \mathrm{~B}$ \\
8 & 19973 & Dewita Deviyanti & $\mathrm{P}$ & $7 \mathrm{~B}$ \\
9 & 19994 & Farah Syifa Fauzia & $\mathrm{P}$ & $7 \mathrm{~B}$ \\
10 & 20027 & Irdina Amalina S & $\mathrm{P}$ & $7 \mathrm{~B}$ \\
11 & 20038 & Keisha Putri N & $\mathrm{P}$ & $7 \mathrm{~B}$ \\
12 & 20044 & Khansa Alma S & $\mathrm{P}$ & $7 \mathrm{~B}$ \\
13 & 20085 & Nada Sylvina Sheila & $\mathrm{P}$ & $7 \mathrm{~B}$ \\
14 & 20086 & Nadhif Aufa Firli W & $\mathrm{L}$ & $7 \mathrm{C}$ \\
15 & 20112 & Puti Alta Maghfira & $\mathrm{P}$ & $7 \mathrm{C}$ \\
16 & 20146 & Salsabila Haura P.S & $\mathrm{P}$ & $7 \mathrm{C}$ \\
17 & 20165 & Tiara Ziyan Z & $\mathrm{P}$ & $7 \mathrm{C}$ \\
18 & 20169 & Tyfa Adrianne P & $\mathrm{P}$ & $7 \mathrm{C}$ \\
19 & 19902 & Adinda Mayhana P & $\mathrm{P}$ & $7 \mathrm{D}$ \\
20 & 19917 & Ananda Aqila T & $\mathrm{P}$ & $7 \mathrm{D}$ \\
21 & 19922 & Anisa Nurmaharani & $\mathrm{P}$ & $7 \mathrm{D}$ \\
22 & 19937 & Aulia Rachman & $\mathrm{P}$ & $7 \mathrm{D}$ \\
23 & 19942 & Ayudhia Puteri M & $\mathrm{P}$ & $7 \mathrm{D}$ \\
24 & 19979 & Adtrian Gita R & $\mathrm{L}$ & $7 \mathrm{D}$ \\
25 & 20004 & Firdaus Aulia R P & $\mathrm{L}$ & $7 \mathrm{D}$ \\
26 & 20066 & Muhammad Azfa H & $\mathrm{L}$ & $7 \mathrm{D}$ \\
27 & 20148 & Sarah Aushaf S & $\mathrm{P}$ & $7 \mathrm{D}$ \\
28 & 20151 & Sevaldo Bargi P & $\mathrm{L}$ & $7 \mathrm{D}$ \\
29 & 20158 & Syannaz Byandra U & $\mathrm{P}$ & $7 \mathrm{E}$ \\
30 & 19927 & Ardila Wida Setiani & $\mathrm{P}$ & $7 \mathrm{E}$ \\
31 & 19956 & Berliana Asti M & & \\
& & & & \\
\hline
\end{tabular}




\begin{tabular}{|c|c|c|c|c|}
\hline 32 & 20045 & Khansa Annora A & $\mathrm{P}$ & $7 \mathrm{E}$ \\
\hline 33 & 20145 & Salsabila Atika L R & $\mathrm{P}$ & $7 \mathrm{E}$ \\
\hline 34 & 20155 & Sifa Aura Amalia N & $\mathrm{P}$ & $7 \mathrm{E}$ \\
\hline 35 & 19933 & Asitha Rizky F & $\mathrm{P}$ & $7 \mathrm{~F}$ \\
\hline 36 & 19968 & Dayana Khalda R & $\mathrm{P}$ & $7 F$ \\
\hline 37 & 19995 & Farahdela Tri P & $\mathrm{P}$ & $7 \mathrm{~F}$ \\
\hline 38 & 20017 & Hasna Muthia M & $\mathrm{P}$ & $7 \mathrm{~F}$ \\
\hline 39 & 20041 & Keysha Lajwa R & $\mathrm{P}$ & $7 \mathrm{~F}$ \\
\hline 40 & 20157 & Syalsa Nurul A & $\mathrm{P}$ & $7 F$ \\
\hline 41 & 19909 & Ali Akbar Alaydrus & $\mathrm{L}$ & $7 \mathrm{G}$ \\
\hline 42 & 19913 & Alym Ashyla Eka P & $\mathrm{P}$ & $7 \mathrm{G}$ \\
\hline 43 & 19951 & Bayu Sukma K & $\mathrm{L}$ & $7 \mathrm{G}$ \\
\hline 44 & 20023 & Ignashia P R & $\mathrm{P}$ & $7 \mathrm{G}$ \\
\hline 45 & 20029 & Jeremy M. D & $\mathrm{L}$ & $7 \mathrm{G}$ \\
\hline 46 & 20092 & Najma Amira M & $\mathrm{P}$ & $7 \mathrm{G}$ \\
\hline 47 & 20124 & Rahmandika Nanda & $\mathrm{L}$ & $7 \mathrm{G}$ \\
\hline 48 & 20170 & Valereyna Jingga $\mathrm{K}$ & $\mathrm{P}$ & $7 \mathrm{G}$ \\
\hline 49 & 20030 & Jessica Adelina P & $\mathrm{P}$ & $7 \mathrm{H}$ \\
\hline 50 & 20055 & Margaretha A. E & $\mathrm{P}$ & $7 \mathrm{H}$ \\
\hline 51 & 20136 & Sabrina Aishadra P & $\mathrm{P}$ & $7 \mathrm{H}$ \\
\hline 52 & 20137 & Sabrina Putri S. A & $\mathrm{P}$ & $7 \mathrm{H}$ \\
\hline 53 & 20154 & Sherly C.V & $\mathrm{P}$ & $7 \mathrm{H}$ \\
\hline 54 & 19950 & Batrolomeus R.Z.B & $\mathrm{L}$ & $7 \mathrm{I}$ \\
\hline 55 & 19953 & Benedict Kevin Rae & $\mathrm{L}$ & $7 \mathrm{I}$ \\
\hline 56 & 20000 & Faustina Exandra G & $\mathrm{P}$ & $7 \mathrm{I}$ \\
\hline 57 & 20018 & Haydnn Caesha M & $\mathrm{L}$ & $7 \mathrm{I}$ \\
\hline 58 & 20081 & Mutiara Sabila & $\mathrm{P}$ & $7 \mathrm{I}$ \\
\hline 59 & 20103 & Novia Safitri & $\mathrm{P}$ & $7 \mathrm{I}$ \\
\hline 60 & 20138 & Sabrina Winda A & $\mathrm{P}$ & $7 \mathrm{I}$ \\
\hline 61 & 20168 & Tyara Sesarini R. NP & $\mathrm{P}$ & $7 \mathrm{I}$ \\
\hline 62 & 19866 & Tiara Julia Pradipta & $\mathrm{P}$ & $8 \mathrm{~A}$ \\
\hline 63 & 19870 & Vania Hasyyati & $\mathrm{P}$ & $8 \mathrm{~A}$ \\
\hline 64 & 19611 & Aerio Rizqi Saputra & $\mathrm{L}$ & $8 \mathrm{~A}$ \\
\hline 65 & 19624 & Amalia Fara Eka P & $\mathrm{P}$ & $8 \mathrm{~A}$ \\
\hline 66 & 19743 & Keysha Diva A. P. S & $\mathrm{P}$ & $8 \mathrm{~A}$ \\
\hline 67 & 19798 & Nathanela Agista I & $\mathrm{P}$ & $8 \mathrm{~A}$ \\
\hline 68 & 19887 & Zevanha Nadiva K & $\mathrm{P}$ & $8 B$ \\
\hline 69 & 19619 & Alfian Syahril Nur I & $\mathrm{L}$ & $8 \mathrm{~B}$ \\
\hline 70 & 19648 & Aulia Afra Kirana & $\mathrm{P}$ & $8 B$ \\
\hline 71 & 19652 & Ayesha Adilla S & $\mathrm{P}$ & $8 \mathrm{~B}$ \\
\hline 72 & 19761 & Fiody Aisyah P & $\mathrm{P}$ & $8 \mathrm{~B}$ \\
\hline 73 & 19801 & Jihan Fatin Ariyanti & $\mathrm{P}$ & $8 B$ \\
\hline 74 & 19723 & Maulida Rozana Z & $\mathrm{P}$ & $8 B$ \\
\hline 75 & 19739 & Nimas Putri L & $\mathrm{P}$ & $8 B$ \\
\hline
\end{tabular}




\begin{tabular}{|c|c|c|c|c|}
\hline 76 & 19723 & Iftina Ika $\mathrm{R}$ & $\mathrm{P}$ & $8 \mathrm{C}$ \\
\hline 77 & 19739 & Kayla Zahra Putri P & $\mathrm{P}$ & $8 \mathrm{C}$ \\
\hline 78 & 19800 & Nesa KaihisTA PUTRI P & $\mathrm{P}$ & $8 \mathrm{C}$ \\
\hline 79 & 19813 & Rahma Hikmawati & $\mathrm{P}$ & $8 \mathrm{C}$ \\
\hline 80 & 19858 & Syafira Putri Ayu D & $\mathrm{P}$ & $8 \mathrm{C}$ \\
\hline 81 & 19677 & Diyana Khorunnisa & $\mathrm{P}$ & $8 \mathrm{D}$ \\
\hline 82 & 19753 & Manjula Mumtaz N & $\mathrm{P}$ & $8 \mathrm{D}$ \\
\hline 83 & 19762 & Meidiana Dyah R & $\mathrm{P}$ & $8 \mathrm{D}$ \\
\hline 84 & 19818 & Rehaneva Swastika & $\mathrm{P}$ & $8 \mathrm{D}$ \\
\hline 85 & 19852 & Shafira Ara M. H & $P$ & $8 \mathrm{D}$ \\
\hline 86 & 19860 & Syahzanan Sahilah & $\mathrm{P}$ & $8 \mathrm{D}$ \\
\hline 87 & 19701 & Febiola Dewita R & $\mathrm{P}$ & $8 \mathrm{E}$ \\
\hline 88 & 19714 & Hadarai Mahmuda A & $\mathrm{L}$ & $8 \mathrm{E}$ \\
\hline 89 & 19722 & Ibnu Tisna Yuwanda & $\mathrm{L}$ & $8 \mathrm{E}$ \\
\hline 90 & 19729 & Irfam Hakim & $\mathrm{L}$ & $8 \mathrm{E}$ \\
\hline 91 & 19730 & Irfan Romadhon & $\mathrm{L}$ & $8 \mathrm{E}$ \\
\hline 92 & 17748 & Larasati HidiaPurti & $\mathrm{P}$ & $8 \mathrm{E}$ \\
\hline 93 & 19770 & Muhammad Ayman L & $\mathrm{L}$ & $8 \mathrm{E}$ \\
\hline 94 & 19784 & Nabila Mutiara T & $\mathrm{P}$ & $8 \mathrm{E}$ \\
\hline 95 & 19785 & Nabila Norhaliza & $\mathrm{P}$ & $8 \mathrm{E}$ \\
\hline 96 & 19791 & Nahira Fatimah A & $\mathrm{P}$ & $8 \mathrm{E}$ \\
\hline 97 & 19857 & Susilo Adi Wibowo & $\mathrm{L}$ & $8 \mathrm{E}$ \\
\hline 98 & 19885 & Zahra Fildza R & $\mathrm{P}$ & $8 \mathrm{E}$ \\
\hline 99 & 19888 & Ziva Putri Yonanta & $\mathrm{P}$ & $8 \mathrm{E}$ \\
\hline 100 & 19625 & Amanda Maisie U & $P$ & $8 \mathrm{~F}$ \\
\hline 101 & 19669 & Devina Neala Arva & $\mathrm{P}$ & $8 \mathrm{~F}$ \\
\hline 102 & 19676 & Diva Vania R & $\mathrm{P}$ & $8 \mathrm{~F}$ \\
\hline 103 & 19725 & Imam Yudha D & $\mathrm{L}$ & $8 \mathrm{~F}$ \\
\hline 104 & 19738 & Katleya Marwah M & $\mathrm{P}$ & $8 \mathrm{~F}$ \\
\hline 105 & 19740 & Keisha Dewi A & $\mathrm{P}$ & $8 \mathrm{~F}$ \\
\hline 106 & 19742 & Keysa Fitra Ardinda & $\mathrm{P}$ & $8 \mathrm{~F}$ \\
\hline 107 & 19764 & Mochammad Rafi B & $\mathrm{L}$ & $8 \mathrm{~F}$ \\
\hline 108 & 19794 & Naja Ghassani W & $\mathrm{P}$ & $8 \mathrm{~F}$ \\
\hline 109 & 19816 & Ranisa Rahma S & $\mathrm{P}$ & $8 \mathrm{~F}$ \\
\hline 110 & 19839 & Sasabiella Dhea A & $\mathrm{P}$ & $8 \mathrm{~F}$ \\
\hline 111 & 19841 & Salsabilla K & $\mathrm{P}$ & $8 \mathrm{~F}$ \\
\hline 112 & 19601 & Abdiel Bellamy T & $\mathrm{L}$ & $8 G$ \\
\hline 113 & 19672 & Diana Aisy Nabiila & $\mathrm{P}$ & $8 G$ \\
\hline 114 & 19721 & Hernina Dinanda P & $\mathrm{P}$ & $8 G$ \\
\hline 115 & 19755 & Maria Fenny R & $\mathrm{P}$ & $8 \mathrm{G}$ \\
\hline 116 & 19804 & Poppy Intan I & $\mathrm{P}$ & $8 G$ \\
\hline 117 & 19829 & Roberto Pascal M & $\mathrm{L}$ & $8 G$ \\
\hline 118 & 19834 & Sabrila M. Piri & $\mathrm{P}$ & $8 G$ \\
\hline 119 & 19878 & Widi Nugreni R. D & $\mathrm{P}$ & $8 \mathrm{G}$ \\
\hline 120 & 19884 & Zacky Arya P & $\mathrm{L}$ & $8 G$ \\
\hline 121 & 19634 & Anindya Azfaghani & $\mathrm{P}$ & $8 \mathrm{H}$ \\
\hline
\end{tabular}




\begin{tabular}{|c|l|l|l|l|}
\hline 122 & 19656 & Bertha Tasya J.R & $\mathrm{P}$ & $8 \mathrm{H}$ \\
123 & 19657 & Birgytta Keythrine & $\mathrm{P}$ & $8 \mathrm{H}$ \\
124 & 19680 & Dyani Restiputri & $\mathrm{P}$ & $8 \mathrm{H}$ \\
125 & 19683 & Elisabeth Shanti R.P & $\mathrm{P}$ & $8 \mathrm{H}$ \\
126 & 19711 & Gagah Sahasika & $\mathrm{L}$ & $8 \mathrm{H}$ \\
127 & 19733 & Izzani Qurata Ayun & $\mathrm{P}$ & $8 \mathrm{H}$ \\
128 & 19747 & Klemens Michelle P & $\mathrm{L}$ & $8 \mathrm{H}$ \\
119 & 19756 & Maria Verena H. P & $\mathrm{P}$ & $8 \mathrm{H}$ \\
130 & 19757 & Maritza Ardila S & $\mathrm{P}$ & $8 \mathrm{H}$ \\
131 & 19772 & Muhammad Farrel A & $\mathrm{L}$ & $8 \mathrm{H}$ \\
132 & 19812 & Rahardian Oka A & $\mathrm{L}$ & $8 \mathrm{H}$ \\
133 & 19874 & Vincentius Noel H.J & $\mathrm{L}$ & $8 \mathrm{H}$ \\
134 & 19609 & Aditya Rachma R & $\mathrm{P}$ & $8 \mathrm{I}$ \\
135 & 19749 & Layla Bonita S & $\mathrm{P}$ & $8 \mathrm{I}$ \\
136 & 19783 & Nabila Maitsa K. A. P & $\mathrm{P}$ & $8 \mathrm{I}$ \\
& & & & \\
\hline
\end{tabular}




\section{LAMPIRAN V SURAT IZIN PENELITIAN}




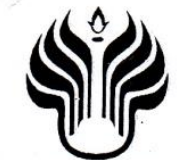

UNNES

KEMENTERIAN RISET, TEKNOLOGI, DAN PENDIDIKAN TINGGI UNIVERSITAS NEGERI SEMARANG

FAKULTAS BAHASA DAN SENI

Gedung B, Kampus Sekaran, Gunungpati, Semarang 50229

Telepon +62248508010 , Faksimile +62248508010 Laman: http://fbs.unnes.ac.id, Email: fbs@unnes.ac.id

Nomor : 5272/UN37.1.2/LT/2016

Lamp. : -

Hal. : Permohonan Izin Penelitian

Yth. Kepala Dinas Pendidikan Kota Semarang

di tempat

Dengan hormat kamı beritahukan bahwa dalam rangka penyusunan skripsi mahasiswa kami,

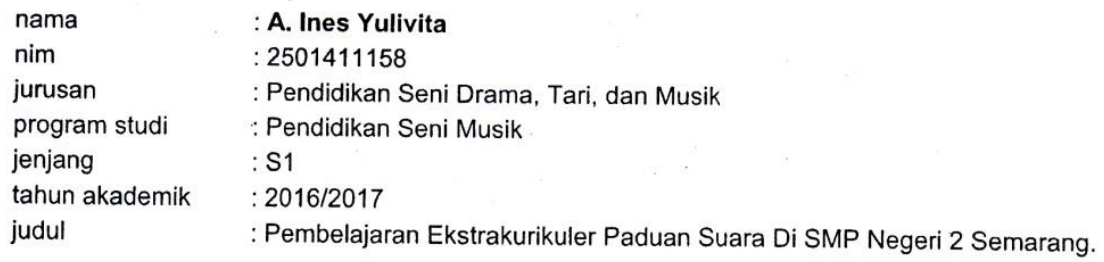

akan mengadakan penelitian di SMP Negeri 2 Semarang, waktu pelaksanaan Desember s.d Januari 2019. Untuk itu kami mohon Saudara berkenan memberikan izin kepada mahasiswa di atas untuk keperluan tersebut.

Atas perhatian dan kerja sama Saudara, kami sampaikan terima kasih.

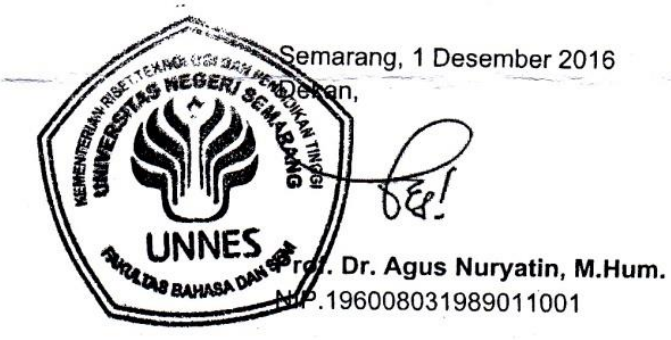

Tembusan:

1. Pembantu Dekan Bidang Akademik

2. Ketua Jurusan

3. Pertinggal 


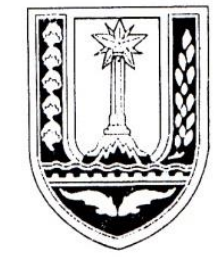

\section{PEMERINTAH KOTA SEMARANG DINAS PENDIDIKAN}

Jalan Dr. Wahidin 118 氶 (024) 8412180 Fax (024) 8317752

Semarang - 50254

website : www.disdik.semarangkota.go.id, e-mail : disdik@semarangkota.go.id

SURAT IJIN KEPALA DINAS PENDIDIKAN KOTA SEMARANG

Nomor : $070 / 10173$

TENTANG IJIN PENELITIAN

Dasar

: Surat dari Universitas Negeri Scmarang (UNNES).

No. 5272/UN37.1.2/LT/2016 Tgl. 1 Desember 2016

Perihal

: Permohonan Ijin Penelitian

Berdasarkan tersebut diatas, Kepala Dinas Pendidikan Kota Semarang mengijinkan

Mahasiswa sebagai berikut:

$\mathrm{N}$ a $\mathrm{m}$ a

A. INES YULIVITA

N I M

2501411158

Jurusan

Pendidikan Seni Drama, Tari dan Musik

$\mathrm{J} u \mathrm{~d} u \mathrm{l}$

Pembelajaran Ekstrakurikuler Paduan Suara Di SMP Negeri 2

Semarang

Untuk mengadakan Penelitian di SMP Negeri 2 Keta Semarang

Dengan memperhatikan hal-hal sebagai berikut :

1. Kegiatan pengambilan data tidak mengganggu kinerja di instansi tersebut.

2. Mentaati peraturan dan ketentuan yang berlaku ditempat pengambilan data tsb.

3. Menyampaikan laporan/pemberitahuan kepada Kepala Dinas Pendidikan kota

Semarang setelah selesai pelaksanaan kegiatan pengambilan data.

4. Kegiatan pengambilan data dilaksanakan sejak dikeluarkannya surat ijin

Kepala Dinas Pendidikan kota Semarang.

Semarang, 7 Desember 2016

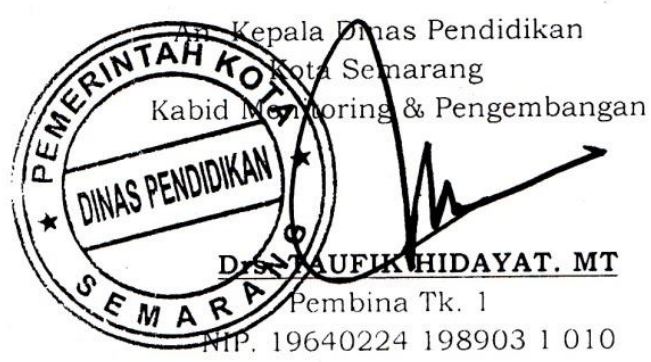




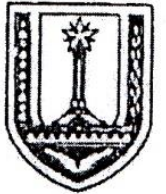

\author{
PEMERINTAH KOTA SEMARANG \\ DINAS PENDIDIKAN
}

\title{
SMP NEGERI 2 SEMARANG
}

Jl. Brigjen. Katamso No. 14 Telp. (024) 8414168 Fax. (024) 8411211 Sernarang-50125

Website : smpn2.semarang kota.go.id .e-mail : smpn2_semarang @ yahoo.com

\section{SURAT KETERANGAN}

Nomor : 046 / 423.4/ 2017

Yang bertanda tangan di bawah ini, Kepala SMP Negeri 2 Semarang menerangkan bahwa :

$\mathrm{N}$ a m a

: A. Ines Yulivita

NIM

: 2501411158

Jurusan

: Pendidikan Seni Drama, Tari, dan Musik

Program Studi

: Pendidikan Seni Musik

Jenjang

: S1

Tahun Akademik

: 2016/2017

Perguruan Tinggi

: Universitas Negeri Semarang

Telah melakukan penelitian di SMP Negeri 2 Semarang pada bulan Januari 2017 dengan judul "Pembelajaran Ekstrakurikuler Paduan Suara Di SMP Negeri 2 Semarang".

Demikian, Surat Keterangan ini dibuat untuk dipergunakan sebagaimana mestinya.

Semarang, 3 Februari 2017

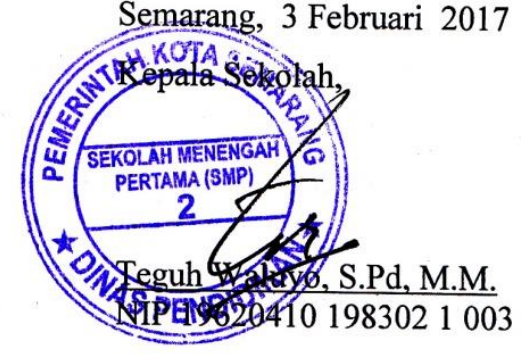

